\title{
ESPÉCIES DE CIGARRINHAS (HEMIPTERA: CICADELLIDAE: CICADELLINAE) EM POMARES DE CITROS DA REGIÃO DE BEBEDOURO (SP)
}

\author{
ROSANGELA CRISTINA MARUCCI \\ Engenheiro Agrônomo
}

Orientador: Prof. Dr. ROBERTO ANTONIO ZUCCHI

Dissertação apresentada à Escola Superior de Agricultura "Luiz de Queiroz", Universidade de São Paulo, para obten ção do título de Mestre em Ciências, Área de Concentração: Entomologia.

PIRACICABA

Estado de São Paulo - Brasil

Outubro - 1998 
Dados Internacionais de Catalogaçāo na Publicaçāo (CIP) DIVISÃO DE BIBLIOTECA E DOCUMENTAÇÃO - Campus "Luiz de Queiroz"/USP

\section{Marucci, Rosangela Cristina}

Espécies de cigarrinhas (Hemiptera: Cicadellidae: Cicalellinae) em pomares de citros da regiāo de Bebedouro (SP) / Rosangela Cristina Marucci. . Piracicaba, 1998.

95 p. : il.

Dissertação (mestrado) - Escola Superior de Agricultura Luiz de Queiroz, 1998. Bibliografia.

1. Cigarrinha-vetora-de-doença 2. Clorose-variegada-dos-citros 3. Entomologia agricola 4. Identificação 5. Inseto 6. Morfologia 7. Ninfa I. Titulo 


\title{
Aos meus Pais: Romário e Marilena;
}

Pelos incentivos, pela força, pela dedicação, pela confiança

e acima de tudo por seu amor e apoio incondicional

A quem devo tudo que sou

\author{
Dedico
}

Aos meus Avós: Luís Armando e Lídia;

Pelos exemplos de determinação e fé

A quem muito admiro e respeito

$\mathrm{e}$

À minha irmã: Regiane;

Companheira de todos os momentos

Pela luz, alegria e união sempre presentes em nossas vidas

A quem muito admiro

Ofereço 


\section{AGRADECIMENTOS}

A Deus, pelo dom da vida, pela luz, coragem, determinação e diposição sempre presentes em minha vida e por seu amparo incondicional em todos os momentos.

Ao Prof. Dr. Roberto Antonio Zucchi, pela orientação, pela confiança, pela oportunidade de trabalhar com esse grupo de insetos e por seus exemplos de profissionalismo e dedicação.

Ao Prof. Dr. Jõao Roberto Spotti Lopes, coordenador do projeto junto ao Fundo Paulista de Defesa da Citricultura (Fundecitrus), pela oportunidade de participar do projeto, viabilizando a realização deste trabalho, pelos incentivos, pela confiança e por todo auxílio prestado desde o início do Curso de Pós Graduação.

Ao Prof. Dr. Rodney Ramiro Cavichioli, da Universidade Federal do Paraná e ao Prof. Gabriel Luis F. Mejdalani da Universidade Federal do Rio de Janeiro, pelas trocas de experiências, pelo auxílio nas identificações e pela simpatia com que sempre me trataram.

A todos os professores do Departamento de Entomologia da ESALQ, pelos ensinamentos transmitidos, em especial ao Prof. Dr. Sinval Silveira Neto, pelos incentivos e ao Prof. Dr. Evôneo Berti Filho por ceder o espaço fisico do seu laboratório para o início deste trabalho.

À Bióloga Dra. Teresinha Augusta Giustolin, pelas coletas, pela confiança, pelas informações, pelo auxílio imprescindível na realização deste trabalho e por sua constante amizade. 
Ao Engenheiro Agrônomo Rodrigo P. P. Almeida por ceder os exemplares imaturos de cigarrinhas, ao estagiário Rodrigo Krügner pelas coletas e ao Engenheiro Agronômo Sérgio R. Roberto pelo envio de material.

À Bióloga Patrícia Milano, por sua amizade e grande auxílio na elaboração dos desenhos.

À CAPES pela concessão da bolsa.

Às bibliotecárias Eliana Maria Garcia Sabino e Kátia Maria de Andrade, da Divisão de Biblioteca e Documentação/ESALQ, pela colaboração durante o Curso de Pós Graduação.

À Regina Célia Botequio de Moraes e Ana Gabriela, do CPD do Departamento de Entomologia da ESALQ, pela amizade e auxílio na utilização do computador durante o Curso de Pós-Graduação.

Às amigas de república Marina e Cláudia, pela amizade, pela união, companheirismo e alegria sempre presentes, que foram imprescíndiveis para minha permanência em Piracicaba.

Ao Engenheiro Agrônomo Silvino Guimarães Moreira, pelos incentivos e por sua compreensão, paciência e carinho.

Aos amigos por todos os momentos compartilhados: Marina, Charles, Mônica, Lino, Maria Aparecida (Cidoca), Teresinha, Sílvia, Lusinério, Jorge, Antônio, Elton e Ranyse e aos colegas do CPD-Entomologia da ESALQ/USP.

A todos os funcionários do Departamento de Entomologia da ESALQ/USP e a todos que contribuíram direta ou indiretamente para realização deste trabalho. 


\section{SUMÁRIO}

Página

LISTA DE FIGURAS.......................................................................... vii

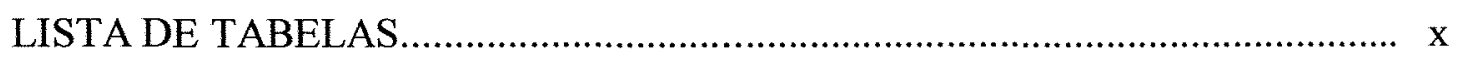

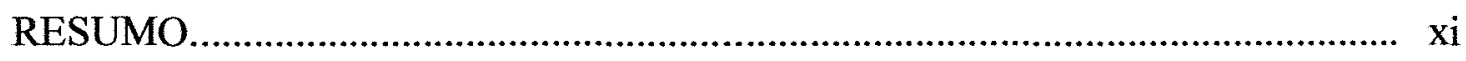

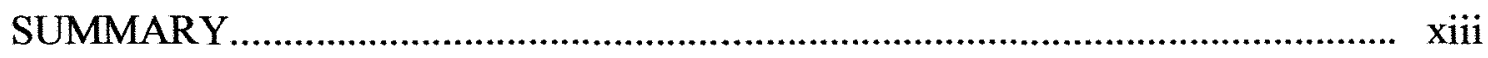

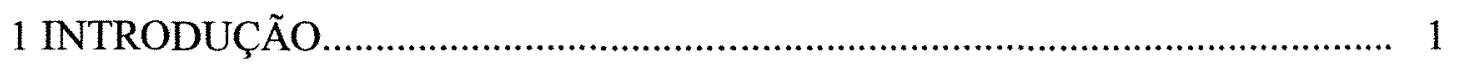

2 REVISÃO DE LITERATURA................................................................ 3

2.1 Subfamília Cicadellinae......................................................................... 3

2.1.1 Aspectos taxonômicos....................................................................... 3

2.1.2 Identificação e caracterização ...................................................................... 5

2.1.3 Espécies associadas às plantas cítricas....................................................... 7

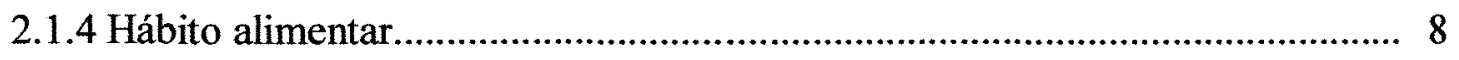

2.1.5 Comportamento de oviposição, desenvolvimento e caracterização ninfal..... 10

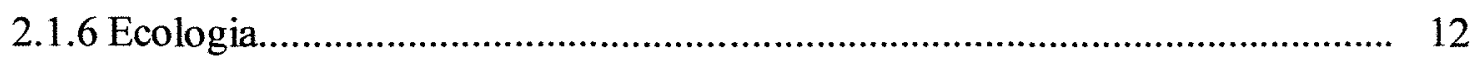

2.1.7 Distribuição geográfica............................................................................ 13

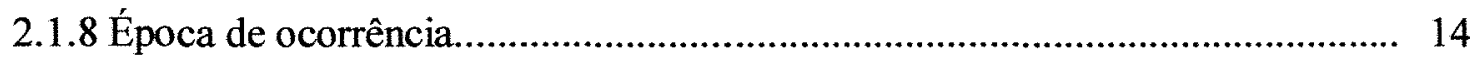

2.1.9 Importância econômica.............................................................................. 14

2.2 A clorose variegada dos citros (CVC)..................................................... 15

2.2.1 A bactéria Xylella fastidiosa................................................................... 16

3 MATERIAL E MÉTODOS................................................................. 18

3.1 Obtenção de amostras de cigarrinhas.......................................................... 18

3.1.1 Rede entomológica.............................................................................. 18

3.1.2 Cartões adesivos amarelos.............................................................. 19

3.1.3 Succionador motorizado................................................................... 19

3.1.4 Armadilhas de Malaise............................................................................. 19

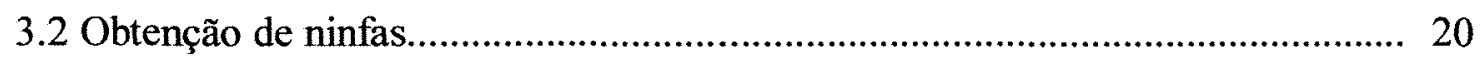

3.3 Montagem do material............................................................................ 20

3.4 Método de preparação das estruturas da genitália............................................ 21 
3.5 Caracterização morfológica.......................................................................... 21

3.6 Ilustrações e medições.................................................................................. 22

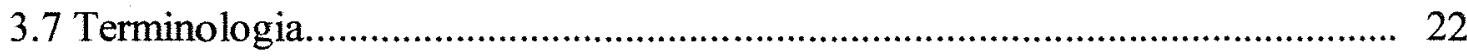

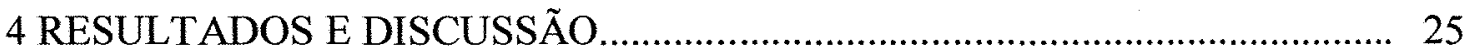

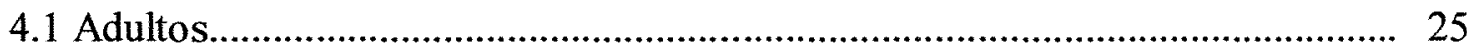

4.1.1 Chave para as tribos de Cicadellinae....................................................... 26

4.1.1.1 Chave para os gêneros e espécies de Proconiini, com base em caracteres

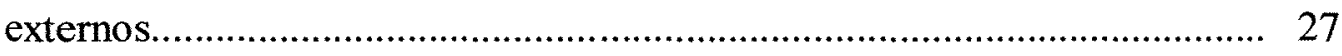

4.1.1.2 Chave para as espécies de Proconiini, com base nas estruturas genitais do macho.

4.1.1.3 Chave para os gêneros e espécies de Cicadellini, com base em caracteres externos

4.1.1.4 Chave para as espécies de Cicadellini, com base nas estruturas genitais do macho.

4.1.2 Caracterização das espécies de cigarrinhas mais comuns nos pomares de citros amostrados

4.2 Ninfas.

4.2.1 Passagem da fase ninfal para a adulta.

4.2.2 Chave para identificação das ninfas do $5^{0}$ ínstar de Acrogonia sp., Dilobopterus costalimai e Oncometopia facialis.

4.2.3 Chave para separação dos ínstares de Acrogonia sp., Dilobopterus costalimai e Oncometopia facialis.

4.2.4 Chave para separação dos sexos de Cicadellidae baseada nos caracteres externos das ninfas do $3^{0}$ ao $5^{0}$ ínstar.

5 CONCLUSÕES. 


\section{LISTA DE FIGURAS}

Página

1 Acrogonia sp. Cabeça, pronoto e escutelo (vista lateral) ...................................... 24

2 Acrogonia sp.(junção fềmur-tíbia não atingindo a margem posterior do proepímero).

3 Dilobopterus costalimai (junção fềmur-tíbia atingindo a margem posterior do proepímero)

4 Teletusa limpida. (A) tíbia anterior (vista lateral); (B e C) cabeça pronoto e escutelo de fềmea e macho (vista dorsal); (D) edeago (vista ventral) (escala A: $1 \mathrm{~mm}$; B e C: $0,4 \mathrm{~mm}$; D: $0,1 \mathrm{~mm}$ ).

5 Homalodisca ignorata. (A e B) cabeça, pronoto e escutelo (vista lateral e dorsal); (C): pigóforo e edeago (vista ventral) (escala A e C: $0,5 \mathrm{~mm}$; B: 0,4 $\mathrm{mm})$.

6 Acrogonia virescens. (A e B) cabeça, pronoto e escutelo de fềmea e macho (vista dorsal); (C) tubo anal (vista ventral); (D) conectivo e estilo (vista dorsal); (E) edeago (vista lateral) (escala A e B: 0,25 mm; C, D e E: 0,32 $\mathrm{mm})$

7 Oragua triplehorni. (A) asa anterior; (B) cabeça, pronoto e escutelo (vista dorsal); (C) processos anteapicais do edeago (vista ventral); (D) edeago (vista lateral) (escala A: 0,4 mm; B: 0,32; C: 0,1 mm; D: 0,25 mm)

8 Parathona gratiosa. (A) asa anterior; (B) cabeça, pronoto e escutelo (vista dorsal); (C): edeago (vista lateral) (escala A e B: 0,4 mm; C: 0,16 mm).

9 Sonesimis grossa. (A) cabeça, pronoto e escutelo (vista dorsal); (B) edeago (vista lateral) (escala: A: 0,4 mm, B: 0,5 mm)

10 Acrogonia sp. (A e B) cabeça, pronoto e escutelo (vista dorsal e lateral); (C) asa anterior; (D) asa posterior; (E) placa subgenital; (F) estilo e conectivo (vista dorsal); (G) edeago (vista lateral); (escala A, B, C e D: 0,5 mm; E e $\mathrm{F}: 0,25 \mathrm{~mm} ; \mathrm{G}: 0,1 \mathrm{~mm})$

11 Bucephalogonia xanthophis (A e B) cabeça, pronoto e escutelo (vista 
dorsal); (C) asa anterior; (D) asa posterior; (E) apódemas abdominais basais do macho; (F) placa subgenital (vista ventral); (G) conectivo e estilo (vista dorsal); (H) edeago (vista ventral); (I) edeago (vista lateral) (escala A, C, D e E: $0,5 \mathrm{~mm} ; \mathrm{B}, \mathrm{F}$ e G: $0,25 \mathrm{~mm}$; $\mathrm{H}$ e I: $0,1 \mathrm{~mm}$ )

12 Dilobopterus costaliamai (A) cabeça, pronoto e escutelo (vista dorsal); (B) asa anterior; (C) asa posterior com o lobo jugal alargado; (D) pigóforo (vista dorsal); (E) placa subgenital (vista ventral); (F) conectivo e estilo (vista dorsal); G) edeago (vista lateral); (H) paráfise (vista dorsal) (escala A, B, C, D e E: $0,5 \mathrm{~mm}$; F: 0,2 mm; G e H: 0,16 mm)

13 Ferrariana trivittata (A) cabeça, pronoto e escutelo (vista dorsal); (B) asa anterior; (C) placa subgenitaL (vista ventral); (D) paráfises e apódemas basais (vista ventral); (E) conectivo e estilo (vista dorsal); (F) edeago (vista ventral) (escala A: $0,4 \mathrm{~mm}$; B: 0,5 mm; C: $0,125 \mathrm{~mm}$; D: 0,2 mm; E e F: 0,25 $\mathrm{mm})$

14 Hortensia similis (A) cabeça, pronoto e escutelo (vista dorsal); (B) placa subgenital (vista dorsal); (C) conectivo e estilo (vista dorsal); (D) edeago (vista ventral); (E) edeago (vista lateral) (escala A: $0,25 \mathrm{~mm}$; B e C: 0,125 $\mathrm{mm}$; D e E: $0,1 \mathrm{~mm}$ ).

15 Macugonalia cavifrons (A) cabeça, protonoto e escutelo (vista dorsal); (B) asa anterior; (C) conectivo e estilo (vista dorsal); (D) edeago (vista lateral). Macugonalia leucomelas (E) cabeça, pronoto e escutelo (vista dorsal); (F) asa anterior; $(\mathrm{G})$ conectivo e estilo (vista dorsal); $(\mathrm{H})$ edeago (vista lateral) (escalas A, B e F: 0,4 mm; E: 0,5 mm; C, G e H: 0,25 mm; D: 0,16 mm)

16 Oncometopia facialis (A) cabeça, pronoto e escutelo (vista dorsal); (B) asa anterior; (C) asa posterior; (D) pigóforo e edeago (vista ventral); (E) conectivo e estilo (vista dorsal); (F) edeago (vista lateral) (escalas: $\mathrm{A}, \mathrm{B}, \mathrm{C} \mathrm{e}$ D: $0,5 \mathrm{~mm}$; E: $0,2 \mathrm{~mm}$; F: 0,25 mm).

17 Plesiommata corniculata (A) cabeça, pronoto e escutelo (vista dorsal); (B) asa anterior; (C) placa subgenital (vista ventral); (D) conectivo e estilo (vista dorsal); (E) edeago (vista ventral); (F) edeago (vista lateral). Plesiommata 
mollicella $(\mathrm{H})$ cabeça, pronoto e escutelo (vista dorsal); (I) edeago (vista ventral); (J) edeago (vista lateral) (escalas A, B: 0,5 mm; C, D, F, H e I: 0,2 $\mathrm{mm}$; E: 0,1 mm; G: 0,25 mm).

18 Ninfas de Acrogonia sp., vista dorsal: (A) $1^{0}$ instar; (B) $2^{\circ}$ instar; (C) $3^{0}$ ínstar; (D) $4^{\circ}$ instar; (E) $5^{\circ}$ ínstar (escala: 0,4 mm).

19 Ninfas de Dilobopterus costalimai, vista dorsal: (A) $1^{\circ}$ ínstar; (B) $2^{\circ}$ instar; (C) $3^{\circ}$ ínstar; (D) $4^{\circ}$ ínstar; (E) $5^{\circ}$ ínstar (escalas A: 0,4 mm; B, C, D e E: 0,5 $\mathrm{mm})$.

20 Ninfas de Oncometopia facialis, vista dorsal: (A) $1^{0}$ ínstar; (B) $2^{0}$ ínstar; (C) $3^{\circ}$ instar; (D) 4ํínstar; (E) $5^{\circ}$ ínstar (escalas: 0,4 mm).

21 Oncometopia facialis. Desenvolvimento dos brotos alares. (A) $1^{0}$ ínstar; (B) $2^{\underline{0}}$ instar; (C) $3^{\underline{0}}$ ínstar; (D) $4^{0}$ ínstar; (E) $5^{\underline{0}}$ instar.

22 Oncometopia facialis vista ventral dos dois últimos segmentos abdominais. (A) terceiro ínstar (macho); (B) terceiro ínstar (fêmea) (escala A: 0,2 mm; B: $0,25 \mathrm{~mm})$.

23 Dilobopterus costalimai, vista ventral dos dois últimos segmentos abdominais. (A) quarto ínstar (macho); (B) quarto ínstar (fềmea) (escala A e B: $0,25 \mathrm{~mm}$ )

24 Oncometopia facialis vista ventral dos dois últimos segmentos abdominais. (A) Quinto ínstar (macho); (B) quinto ínstar (fềmea) (escala A: 0,4.mm; B: $0,32 \mathrm{~mm})$ 


\section{LISTA DE TABELAS}

Página

1 Média ( \pm DP) e amplitude, em milímetros, de diversos parâmetros dos estágios ninfais de Acrogonia sp., criados em mudas cítricas (Citrus sinensis L.)............ 67

2 Média $( \pm \mathrm{DP})$ e amplitude, em milímetros, de diversos parâmetros dos estágios ninfais de Dilobopterus costalimai, criados em mudas citricas (Citrus sinensis

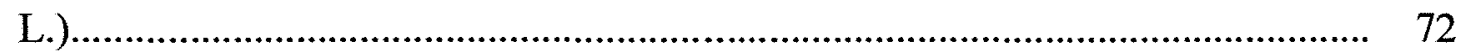

3 Média ( \pm DP) e amplitude, em milímetros, de diversos parâmetros dos estágios ninfais de Oncometopia facialis, criados em mudas cítricas (Citrus sinensis

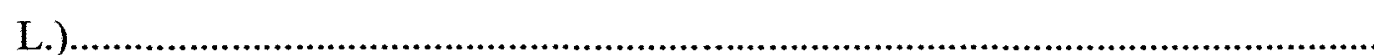




\title{
ESPÉCIES DE CIGARRINHAS (HEMIPTERA: CICADELLIDAE: CICADELLINAE) EM POMARES DE CITROS DA REGIÃO DE BEBEDOURO (SP)
}

\author{
Autora: ROSANGELA CRISTINA MARUCCI \\ Orientador: Prof. Dr. ROBERTO ANTONIO ZUCCHI
}

\section{RESUMO}

Dezesseis espécies de Cicadellidae, da subfamília Cicadellinae foram identificadas: 11 da tribo Cicadellini e cinco da tribo Proconiini. As dez espécies mais comuns foram caracterizadas com base na morfologia externa e na genitália masculina: Acrogonia sp.; Bucephalogonia xanthophis (Berg, 1879); Dilobopterus costalimai Young, 1977; Ferrariana trivittata (Signoret, 1854); Hortensia similis (Walker, 1851); Macugonalia cavifrons (Stål, 1862); M. leucomelas (Walker, 1851); Oncometopia facialis (Signoret, 1854); Plesiommata corniculata Young, 1977 e P. mollicella (Fowler, 1900). As amostras de cigarrinhas foram coletadas em três pomares de citros e em hábitats adjacentes (florestas, brejo, várzea, vegetação espontânea do pomar, cafeeiro e cana-de-açúcar) nos municípios de Bebedouro e Monte Azul Paulista e no distrito de Turvínia. Os métodos de coleta foram: rede entomológica, cartões adesivos amarelos, succionador motorizado e armadilhas de Malaise. Foram caracterizados também os ínstares ninfais das espécies Acrogonia sp., D. costalimai e $O$. facialis. Elaboraram-se chaves de identificação para as 16 espécies (adultos) e para as ninfas de quinto ínstar de Acrogonia sp., D. costalimai e $O$. facialis. Chaves para o reconhecimento dos ínstares e distinção de machos e fềmeas das ninfas a partir do terceiro ínstar foram também elaboradas. Há uma grande diversidade de cicadelíneos nos pomares cítricos. Os gêneros podem ser separados facilmente com base em caracteres externos. No entanto, a 
utilidade da morfologia externa é limitada e o exame dos caracteres da genitália masculina é freqüentemente necessário para a identificação específica. Nas três áreas amostradas, foi coletado um maior número de espécies da tribo Cicadellini do que da tribo Proconiini. Na região de Bebedouro, as espécies vetoras de Xylella fastidiosa, Acrogonia sp., B. xanthophis, D. costalimai e $O$. facialis, foram coletadas nos pomares de citros e em todos os hábitats adjacentes. $O$ estudo morfológico das ninfas permite o reconhecimento dos estágios imaturos das três espécies de cigarrinhas vetoras de $X$. fastidiosa bem como a distinção dos ínstares e a sexagem 


\title{
SHARPSHOOTER LEAFHOPPERS (HEMIPTERA: CICADELLIDAE: CICADELLINAE) IN CITRUS ORCHARDS OF THE AREA OF BEBEDOURO (SP)
}

\author{
Author: ROSANGELA CRISTINA MARUCCI \\ Adviser: Prof. Dr. ROBERTO ANTONIO ZUCCHI
}

\section{SUMMARY}

Sixteen species of Cicadellidae, subfamily Cicadellinae were identified: 11 of the tribe Cicadellini and five of the tribe Proconiini. The ten most common species were characterized based on external morphology and male genitalia: Acrogonia sp.; Bucephalogonia xanthophis (Berg, 1879); Dilobopterus costalimai Young, 1977; Ferrariana trivittata (Signoret, 1854); Hortensia similis (Walker, 1851); Macugonalia cavifrons (Stål, 1862); M. leucomelas (Walker, 1851); Oncometopia facialis (Signoret, 1854); Plesiommata corniculata Young, 1977 e P. mollicella (Fowler, 1900). The leafhopper samples were collected in citrus orchards and in adjacent habitats (woods, swamp, cultivable plain, spontaneous vegetation of the orchard, coffee crop and sugarcane) at the counties of Bebedouro and Monte Azul Paulista and in the district of Turvínia. The collecting methods were: insect net, yellow sticky cards, portable suction trap and Malaise trap. The nymphal instars of the species Acrogonia sp., D. costalimai and $O$. facialis were also characterized. Identification keys were elaborated for the 16 species (adults) and for nymphs of the fifth instar of the species Acrogonia sp., $D$. costalimai and $O$. facialis. Keys for recognition of nymphal instars and to distinguishing males and females of third instar were elaborated as well. There is a great diversity of Cicadellinae species in the citric orchards. Genera can be easily separated based on external characters. However, the usefulness of external morphology for specific 
identification is limited and the examination of male genitalia characters is often necessary. In the three areas sampled, it was collected a larger number of species of the tribe Cicadellini than of the tribe Proconiini. In the Bebedouro area, the vector species of Xylella fastidiosa, Acrogonia sp., B. xanthophis, D. costalimai and O. facialis, were collected in the citrus orchards and in all adjacent habitats. Based on morphology it is possible to recognize the imature stages of three sharpshooter vectors $X$. fastidiosa, as well as to differentiate instars and to separate sexes. 


\section{INTRODUÇÃo}

O Brasil é disparadamente o maior produtor mundial de citros com aproximadamente 19 milhões de toneladas no balanço mundial de laranja em 1997, seguido pelos Estados Unidos, México e Espanha (FNP Consultoria, 1998). A cultura encontra-se disseminada por todo o território nacional, com grande importância econômica e social para os estados de São Paulo, Sergipe, Rio de Janeiro, Minas Gerais, Rio Grande do Sul e Bahia, onde se situa entre as dez principais culturas (Amaro et al., 1991). O Estado de São Paulo é individualmente o maior produtor mundial de laranja, detendo ao redor de $1 / 4$ da produção. A exportação de frutas de mesa é marginal, enquanto se exporta ao redor de $97 \%$ da produção estadual de suco concentrado (Neves et al., 1995).

No entanto, com o surgimento da clorose variegada dos citros (CVC) em pomares no norte e nordeste do Estado de São Paulo, em 1987 (Rossetti \& De Negri, 1990), que se difundiu rapidamente na citricultura paulista (Tubelis et al., 1993), todo potencial produtivo brasileiro começou a ser ameaçado. A CVC tornou-se a mais importante doença em citros no Brasil (Laranjeira et al., 1998), não só pelo custo de defesa dos pomares, mas pelas perdas que ocorrem pela morte prematura de plantas produtivas e comprometimento da renovação dos pomares.

Os principais agentes disseminadores da doença em pomares cítricos são algumas espécies de cigarrinhas da familia Cicadellidae, subfamília Cicadellinae (Lopes, 1996a). Essas cigarrinhas, assim como a bactéria Xylella fastidiosa, alimentam-se da seiva dos vasos do xilema (Lee et al., 1993). Cinco espécies de cigarrinhas já foram comprovadas como transmissoras da bactéria: Acrogonia sp., Dilobopterus costalimai Young, 1977, Oncometopia facialis (Signoret, 1854) (Lopes et al., 1996; Roberto et al., 
1996), Bucephalogonia xanthophis (Berg, 1879) e Plesiommata corniculata Young, 1977 (Krügner et al., 1998) por se alimentarem freqüentemente da planta cítrica e das plantas invasoras do pomar, principalmente gramíneas.

Para o estabelecimento de um sistema de manejo eficiente para a contenção dos vetores da CVC, é necessário o conhecimento da taxonomia e morfologia de adultos e ninfas das cigarrinhas vetoras comprovadas e em potencial. Aliando-se esses conhecimentos 'a ecologia, ao comportamento, aos mecanismos de transmissão e aos inimigos naturais será possível obter-se um método que impeça a disseminação da doença.

Dessa forma, este trabalho teve por objetivos a caracterização de cigarrinhas da família Cicadellidae (subfamília Cicadellinae, tribos Proconiini e Cicadellini) comprovadamente vetoras de CVC e potenciais, com a elaboração de chave de identificação para as principais espécies de cigarrinhas coletadas em pomares de citros na região de Bebedouro (SP) e a caracterização dos ínstares ninfais de três espécies de cigarrinhas vetoras de $\mathrm{CVC}$. 


\section{REVISÃO DE LITERATURA}

\subsection{Subfamília Cicadellinae}

\subsubsection{Aspectos taxonômicos}

As cigarrinhas geralmente não causavam danos em citros. Pela sucção do xilema, elas não lesam as plantas, a menos que ocorram em grande número. No entanto, insetos sugadores do xilema em citros são pragas, pois causam danos indiretos pela transmissão de $X$. fastidiosa. As cigarrinhas encontradas na cultura dos citros não são muito conhecidas e apenas recentemente tem sido mais estudadas, pois são vetoras da clorose variegada do citros (CVC) (Purcell, 1994).

A família Cicadellidae é a mais numerosa em espécies, entre os Auchenorrhyncha. As subfamílias Cicadellinae e Deltocephalinae, as mais evoluídas filogeneticamente (Nielson, 1985), têm maior representatividade, embora existam poucos trabalhos de revisão e registros de ocorrência (Cavichioli \& Zanol, 1991).

A subfamília Cicadellinae compreende duas tribos: (1) Proconiini com 55 gêneros e aproximadamente 350 espécies, distribuídas em todo hemisfério ocidental, inclue os maiores cicadelíneos (Young, 1968) e (2) Cicadellini com 155 gêneros e cerca de 1100 espécies, ocorre em todo o mundo; nas regiões Neártica e Neotropical encontram-se os cicadelíneos de menor porte (Young, 1977).

Os caracteres que definem Proconiini e Cicadellini apresentam poucas variações nos diversos gêneros. Em Proconiini, as espécies, os gêneros e os grupos de gêneros são bem definidos, enquanto em Cicadellini há problemas na caracterização dessas categorias (Young, 1968, 1977). 
De modo geral, há um reduzido número de publicações sobre a morfologia das duas tribos. Assim, estudos especialmente para as espécies da Região Neotropical, onde as tribos apresentam maior diversidade taxonômica e morfológica, podem fornecer novos caracteres para a resolução dos problemas taxonômicos (Melichar, 1924; Osborn, 1926; Metcalf, 1965). A complexidade e o tamanho do grupo, a falta de afinidades entre muitas famílias, a quase ausência de estudos taxonômicos das ninfas e a falta de conhecimento do potencial dos caracteres filogenéticos são enormes lacunas na fauna tropical (Nielson, 1985).

A avaliação dos caracteres primitivos e dos derivados a partir dos estudos de formas imaturas é o requerimento básico para o desenvolvimento filogenético do som em Cicadellidae. A taxonomia de ninfas precisa ser desenvolvida. Uma reavaliação dos caracteres morfológicos, até então considerados primitivos, deve ser feita, mas somente após a fauna mundial ser melhor conhecida (Nielson, 1985).

As ninfas e os adultos de cigarrinha excretam com as fezes um fluido especial, chamado brocossomos, contendo produtos dos tubos de Malpighi e aplicam-no sobre a superfície do corpo (May \& Briggs, 1958). A característica estrutura das pernas de Cicadellidae está claramente associada com a distribuição dos brocossomos sobre a cutícula, mostrando um papel chave de sua especialização na origem e evolução da família (Rakitov, 1996). A presença de brocossomos pode ser de significância taxonômica, pois não ocorrem em todas as espécies de cigarrinhas. $\mathrm{O}$ exame da fina estrutura do integumento fornece uma riqueza de informação morfológica, cujo potencial é aplicável em estudos filogenéticos (Dietrich, 1989).

Todos os membros da subfamília Cicadellinae alimentam-se do xilema sem danificá-lo, indicando não somente uma correlação entre uma função biológica $\mathrm{e}$ morfológica (clípeo dilatado), mas também uma base biológica para identificação e separação da subfamília (Nielson, 1985; Purcell, 1994). 


\subsubsection{Identificação e caracterização}

Os cicadelíneos incluem um imenso número de espécies, muitas das quais são coloridas e de forma peculiar. Tem sido um problema para os sistemáticos pela grande quantidade de espécies em posições taxonômicas incertas. Os caracteres nãodependentes têm sido encontrados para separação de gêneros e distinção das espécies, mas em muitos casos a genitália parece oferecer caracteres mais confiáveis, especialmente para separação de espécies (Osborn, 1926)

Signoret foi o primeiro a estudar a subfamília Cicadellinae. Incluiu 396 espécies, 388 delas com descrições detalhadas, muitas em pranchas coloridas. Todas as espécies foram colocadas no gênero Tettigonia (pré-ocupado em Orthoptera), mas indicou sub-grupos, alguns dos quais mais tarde foram elevados à gênero por Stål e outros (Osborn, 1926).

Os caracteres morfológicos têm sido utilizados predominantemente para a classificação de cigarrinhas, particularmente a asa (tipo, forma, nervação), cabeça (coroa e posição dos ocelos), forma geral do corpo e estruturas genitais de ambos os sexos. Os caracteres das estruturas da cápsula genital do macho (estilos, edeago, conectivo, placas, pigóforo) e apódemas, na porção anterior do abdome, têm sido utilizados especialmente para a separação de espécies (DeLong, 1971).

A identificação de cigarrinhas é baseada inteiramente em caracteres morfológicos de espécies dissecadas. Dados de plantas hospedeiras, comportamento, preferências ecológicas, e outros conhecimentos de biologia têm sido importantes para caracterizar a espécie, mas esses critérios não têm base para a identificação (Nielson, 1985). Por serem vetoras de doenças, a compreensão da posição específica e interrelações genéticas entre populações é importante (Claridge, 1985).

Edwards $(1878)^{1}$, segundo Nielson (1985), relatou pela primeira vez a importância das estruturas da genitália do macho na diferenciação das espécies. De

\footnotetext{
${ }^{1}$ EDWARDS, J. Description of a new British Typhlocyba. Entomologist's Monthly Magazine, v.14, p.248, 1878.
} 
acordo com Lawson $(1920)^{2}$, citado por Young (1968), a genitália do macho permite a identificação das espécies de Cicadellidae.

A taxonomia da subfamília Cicadellinae é principalmente baseada em caracteres da genitália do macho. As chaves de identificação de muitos gêneros e espécies são exclusivas para espécies de machos. Esse fato determina a existência de alguns gêneros e um grande número de espécies conhecidas somente pelos machos. Como resultado, a identificação das fềmeas é freqüentemente feita por comparação com os machos (Young, 1968, 1977; Dietrich \& Pooley, 1994). Algumas características da segunda valva do ovipositor das fềmeas possibilitam a separação de gêneros dentro do grupo Juliaca (Mejdalani, 1995). Entretanto, é possível a identificação sem dissecação de cigarrinhas do gênero Draeculocephala, utilizando-se os caracteres morfológicos externos (Dietrich \& Pooley, 1994).

O tamanho e a coloração são considerados caracteres variáveis, portanto, devem ser utilizados com cuidado (Blocker \& Triplehorn, 1985). Viraktamath (1983) ${ }^{3}$, citado por Blocker \& Triplehorn (1985), relatou o extensivo uso da cor na separação de espécies de cigarrinhas de importância econômica na Índia.

Para os cicadelídeos em geral, variações de temperatura e fotoperíodo influenciam o desenvolvimento de ninfas e o tamanho e coloração (pigmentação) dos adultos. As diferenças existentes entre o inverno e o verão causam alterações não só nas características fisiológicas dos insetos como também em suas características morfológicas (tamanho, forma e padrão de cor), e formas estacionais poderiam ser descritas como espécies distintas (Müller, 1979). O tamanho do adulto é infuenciado por fatores ambientais, que atuam durante o estágio ninfal (temperatura, fotoperiodo e

\footnotetext{
${ }^{2}$ LAWSON, P.B. The Cicadellidae of Kansas. Kansas University Science Bulletin, v.12, p.5-306, 1920.

3 - VIRAKTAMATH, C.A. Genera to be revised on a priority basis. The need for keys and ilustrations of economic species of leafhoppers and preservation of voucher specimens in recognized institutions. In: INTERNATIONAL WORKSHOP ON LEAFHOPPERS AND PLANTHOPPERS OF ECONOMIC IMPORTANCE., 1., London, 1983. London: Commonwealth Institute of Entomology, 1983 p.471-492.
} 
condição da planta hospedeira) (Harrison, 1980). Diferenças no corpo e comprimento das asas em Empoasca foram encontradas em diferentes temperaturas (Simonet \& Pienkowski, 1980). Populações de Dalbulus maidis (DeLong \& Wolcott) coletadas em

algumas localidades do Brasil apresentaram variação morfológica, sendo que as populações da região nordeste exibiram menor peso, tamanho e pigmentação em relação as da região centro-sul (Oliveira, 1996).

A coloração é geralmente utilizada para separar grupos de gêneros e categorias inferiores. Muitas subfamílias, como Cicadellinae e Typhlocybinae, têm espécies muito coloridas, mas há muita variação e essa informação raramente é utilizada na elaboração de chaves (Blocker \& Triplehorn, 1985). Segundo Evans (1947), a cor predominante de muitos grupos primitivos é a marron, seguida pelo verde, laranja, amarelo, vermelho, preto e branco. O tamanho é mais difícil de ser utilizado do que a cor (o tamanho das cigarrinhas varia de 2 a $30 \mathrm{~mm}$ ) (Blocker \& Triplehorn, 1985).

As modificações nas estruturas genitais das cigarrinhas oscilam desde pequenas alterações morfológicas até total falta de desenvolvimento normal das estruturas, que freqüentemente levam a erros de classificação e identificação das espécies. Essas modificações ocorrem em ambos os sexos. Anormalidades genitais podem ser comumente causadas por parasitóides das ordens Strepsiptera, Diptera (Pipunculidae), Hymenoptera (Dryinidae) e por nematóides. O parasitismo não afeta somente os estilos, edeago e outras estruturas dos segmentos genitais, mas também os apódemas esternais do segmento abdominal e padrões de cor (Blocker \& Triplehorn, 1985).

\subsubsection{Espécies associadas às plantas cítricas}

No Brasil, na cultura dos citros existem mais de 70 espécies de cigarrinhas pertencentes a oito famílias, que podem ser observadas tanto nas plantas como na vegetação espontânea do pomar (Paiva et al., 1996). Entre as famílias de cigarrinhas que ocorrem em citros, Cicadellidae é a mais numerosa, com 11 subfamílias e mais de 55 espécies (Yamamoto, 1996). Na Argentina, 76\% das espécies coletadas em pomares de 
Montecarlo pertenciam à família Cicadellidae (Coll et al., 1998b). Em levantamento realizado em pomar comercial de citros no município de Limeira, foram coletadas 38 espécies de cigarrinhas pertencentes a família Cicadellidae, das quais dez eram da subfamília Cicadellinae (Silveira Neto et al., 1983).

De acordo com Yamamoto (1996), há uma diferenciação bastante nítida de espécies que ocorrem em plantas cítricas e, aquelas que aparecem na vegetação invasora dos pomares. Entre as que se encontram nas plantas daninhas, as mais abundantes são Sonesimia grossa (Signoret), Hortensia similis (Walker), Haldorellus divergens Menezes, Planicephalius flavicosta Stål, Plesiommata corniculata Young, Protalebrella brasiliensis Baker, Chlorotettix minimus Baker, Xerophloea viridis (Fabricius), Ferrariana trivittata (Signoret), Carneocephala reticulata (Signoret) e Stirellus bicolor Van Duzee. Com relação às que ocorrem em plantas cítricas destacam-se Tapajosa ocellata (Osborn, 1926), Acrogonia sp., Oncometopia facialis (Signoret) (Proconiini) e Dilobopterus costalimai Young (Cicadellini). Dentre os cicadelíneos, potencialmente vetores da bactéria por se alimentarem da seiva do xilema, existem espécies que, embora ocorram predominantemente nas plantas invasoras, podem eventualmente ser encontradas na planta cítrica, tais como $C$. reticulata, Ciminius sp., $F$. trivittata, $H$. similis e P. corniculata. Outras como Bucephalogonia xanthophis (Berg), Syncharina punctatissima (Signoret), Macugonalia leucomelas (Walker) e Macugonalia sp. aparecem em proporções semelhantes nas plantas invasoras e no citros. D. costalimai é a única espécie da tribo Cicadelliini encontrada exclusivamente nas laranjeiras. Diedrocephala continua Sakakibara \& Cavichioli, Oragua discoidula (Osborn), Sibovia sagata (Signoret) e $S$. grossa raramente ocorrem sobre a planta de citros. Embora a tribo Proconiini contenha espécies que vivam predominantemente sobre plantas arbóreas, observou-se que Dechacona missionum (Berg), vive unicamente nas plantas invasoras do pomar. Em plantas de citros, predominam três espécies comprovadamente vetoras da bactéria $X$. fastidiosa: $O$. facialis, Acrogonia sp. e D. costalimai.

Das espécies identificadas como de ocorrência nos sistemas ecológicos formados pelos pomares, pode-se reunir as cigarrinhas do xilema em três grupos principais: 1) grupo das gramíneas - predominância nas gramíneas intercalares e 
adjacentes dos pomares - por exemplo, H. similis; 2) grupo das arborígenas predominância nas plantas cítricas e arbustos em geral - por exemplo, O. facialis e 3) grupo de indiferentes - parte do tempo comporta-se como as dos dois grupos anteriores por exemplo $B$. xanthophis. Os talhões próximos às matas têm forte tendência a apresentar mais cigarrinhas que os demais. Entretanto, não se pode condicionar a proximidade de matas com a incidência, pois têm-se observado talhões que, sistematicamente, apresentam cigarrinhas mesmo não estando próximos às matas (Gravena et al., 1997).

\subsubsection{Hábito alimentar}

A capacidade de transmissão de doenças pelas cigarrinhas da subfamilia Cicadellinae está relacionada ao fato desses insetos se alimentarem única e exclusivamente no xilema. Portanto, apresentam a musculatura de cabeça bastante desenvolvida para sucção da seiva, que circula sobre forte pressão negativa na planta (Young, 1968; Nielson, 1985; Wilson \& Claridge, 1991; Browning et al. 1995). Essas cigarrinhas são dotadas de clípeo bem desenvolvido, seguido ventralmente por um aparelho bucal com múltiplos músculos, necessários para retirar a seiva do xilema. A correlação com a morfologia do clípeo é o maior caráter taxonômico do grupo e o local de alimentação é um indicativo seguro da sua taxonomia (Nielson, 1985). Poucas

cigarrinhas se especializaram, evolutivamente, em se alimentar no xilema e, provavelmente, essas sejam as mais eficientes em transmitir $X$. fastidiosa de uma planta para outra (Frazier, 1944; Purcell, 1994; Paiva et al., 1996).

Como a maioria dos representantes da ordem Hemiptera, esses insetos são fitófagos, alimentando-se por sucção da seiva dos brotos, folhas, pecíolos, hastes e mesmo raízes expostas, de acordo com as preferências de cada espécie. As ninfas alimentam-se nas folhas e os adultos utilizam troncos, hastes, pecíolos e pedúnculos das plantas (Menezes, 1972; Browning et al., 1995). Eliminam copiosas quantidades diluídas de honeydew, sendo por essa razão chamados freqüentemente de sharpshooters (Wilson \& Claridge, 1991). 
A espécie $D$. costalimai se alimenta da haste de brotações dos citros. Oncometopia sp. também suga a haste de brotações ou ramos novos, enquanto Acrogonia sp. alimenta-se, principalmente, de folhas novas (Lopes, 1996b).

\subsubsection{Comportamento de oviposição, desenvolvimento e caracterização ninfal}

A postura de cigarrinhas é endofítica (com exceções), sendo os ovos introduzidos nos tecidos vegetais com auxilio do ovipositor bem desenvolvido. A superfície inferior das folhas, pedúnculos e pecíolos tenros são usualmente selecionados para oviposição por apresentarem maior teor de umidade. As fêmeas são capazes de colocar um grande número de ovos, mais de mil em algumas espécies. As formas jovens são bastante ativas e sofrem cinco ecdises até atingirem o estágio adulto. As fêmeas de algumas espécies da Tribo Proconiini excretam grandes gotas de um fluido do ânus, que é espalhado através dos longos espinhos das tíbias posteriores, recobrindo os ovos onde se solidificam, protegendo-os contra eventuais bactérias, predadores e parasitóides. Freqüentemente esse líquido é também depositado sobre o dorso das asas anteriores, formando uma mancha branca (Swain, 1936; Turner \& Pollard, 1959; DeLong, 1971; Menezes, 1972; Nielson et al., 1975; Browning et al. 1995; Triapitsyn, 1998).

Segundo Pollard \& Yonce (1965), parece haver uma relação entre o desenvolvimento dos espinhos tibiais das fềmeas e a secreção e cobertura dos ovos, principalmente para as espécies Homalodisca insolida (Walker); Oncometopia orbona (Fabricius) e Oncometopia nigricans (Walker) que produzem essa secreção e fazem uma cobertura densa sobre a postura com os espinhos tibiais. Homalodisca coagulata (Say) está equipada parcialmente com os espinhos tibiais, cobrindo suas posturas levemente, sendo que essa cobertura praticamente não é notada após um ou dois dias. Em espécies que não excretam este material, os pentes tibiais não são desenvolvidos.

D. costalimai e Oncometopia sp. passam por cinco ínstares. O ciclo de ovo a adulto dura aproximadamente onze e doze semanas, respectivamente. Alta mortalidade de ninfas ( $80 \%)$ foi observada para as duas espécies sob condições de casa de vegetação, principalmente no primeiro ínstar (Lopes, 1996b). 
A descrição dos estágios imaturos é uma lacuna no conhecimento da biologia de muitas espécies de insetos. Segundo Decoursey \& Esselbaugh (1962), esses estudos auxiliam a compreender problemas associados à taxonomia, morfologia e entomologia econômica. Estimativas populacionais pressupõem o reconhecimento e distinção de indivíduos imaturos. Esses dados têm igual importância para a compreensão das variações no tamanho da população, processos de regulação e construção de tabelas de vida (Southwood, 1978).

São raros os trabalhos de caracterização dos estágios imaturos de cigarrinhas e os que existem são muito superficiais. Turner et al. (1959) apresentaram algumas características dos ínstares ninfais de cinco espécies de cigarrinhas consideradas vetoras da Phony Peach nos EUA, H. coagulata, Oncometopia undata (Fabricius), Graphocephala versuta (Say), Cuerna costalis (Fabricius) e H. insolida. Nielson (1975) ao estudar a biologia de Oncometopia alpha Fowler, apresentou alguns dados comparativos e ilustrações dos cinco ínstares. A presença constante de distintas, finas e escuras linhas nos dois lados da margem anterior da coroa, a partir do centro, ocorrem em todos os ínstares de $O$. alpha e também em Homalodisca lacerta (Fowler), $O$. orbona, $H$. coagulata e $H$. insolida, sendo ausentes nos adultos.

É uma vantagem para os programas de controle de pragas a capacidade de identificar os estágios imaturos de muitas espécies (Wilson \& Claridge, 1991), principalmente no caso de insetos vetores em que tanto a fase ninfal como a adulta transmite patógenos.

Wilson \& Claridge (1991) elaboraram uma chave para a identificação das ninfas de cigarrinhas de quinto ínstar encontradas em arroz, na Ásia. Na chave, características morfológicas, assim como quetotaxia, têm sido utilizadas ao invés da coloração. Esses caracteres são menos variáveis do que alguns padrões de cor, que se alteram em razão da distribuição geográfica. Entretanto, em algumas espécies são menos variáveis que em outras, e nesse caso, padrões de cor e marcas podem ser confiáveis.

Os rudimentos da genitália externa tornam-se visíveis nas ninfas a partir do quinto instar. Kathirithamby (1974) descreveu o desenvolvimento da genitália externa de cinco espécies de Cicadellidae: Ulopa reticulata (Fabricius), Doratura stylata 
(Boheman), Cicadula persimilis (Edwards), Mocydiopsis parvicauda Ribaut, Balclutha punctata (Thunberg) e Zygina scutellaris (Herrich-Schaeffer). Mochida (1970) descreveu o desenvolvimento da genitália externa no cicadelídeo Nephotettix cincticeps (Uhler). Em Cicadellidae é possivel separar machos e fềmeas a partir do terceiro ínstar (Wilson \& Claridge, 1991).

Os ínstares ninfais podem ser separados pelo relativo desenvolvimento dos brotos alares no tórax. Os estágios ninfais de $N$. cinctipes foram diferenciados usando esses caracteres (Mochida, 1970). Para o reconhecimento dos ínstares ninfais, algumas chaves utilizam o tamanho dos brotos alares em relação aos segmentos abdominais, no entanto, quando as ninfas são preservadas em álcool, um aumento pode ocorrer e essas medidas tornam-se imprecisas. Alguma dificuldade tem sido encontrada na separação do primeiro e segundo ínstares por causa do tamanho e desenvolvimento limitado dos brotos alares (Wilson \& Claridge, 1991).

\subsubsection{Ecologia}

As cigarrinhas são atraídas pela coloração amarela e, portanto, essa cor tem sido utilizada em armadilhas adesivas (Purcell, 1994).

$\mathrm{Na}$ Flórida, populações de cigarrinhas tendem a aumentar sazonalmente. As plantas jovens são particularmente atrativas para os adultos de cigarrinhas, que podem ser encontrados sobre os galhos verdes. As espécies mais comuns apresentam longevidade do adulto acima de 65 dias, diversas gerações/ano, postura endofítica e quiescência de adultos em hábitat de floresta (Browning et al., 1995).

Nas horas mais quentes do dia são mais ágeis, movimentando-se rapidamente. Já ao amanhecer, principalmente nos dias mais frios não se movimentam. Têm preferência pela face da planta onde não incidem diretamente os raios solares e pelas brotações do ponteiro, que se sobressaem (Gravena et al., 1997).

Os principais inimigos naturais são os parasitóides de ovos, himenópteros das famílias Mymaridae e Trichogrammatidae. Em adultos, tem-se observado parasitóides da Ordem Strepsiptera (Coll, 1996), várias espécies de aranhas, algumas de percevejo e 
o fungo Beauveria bassiana (Gravena et al., 1997). Os ovos de H. coagulata, espécie que se alimenta de citros nos Estados Unidos, são parasitados durante o verão por algumas espécies de Mymaridae (Gonatocerus ashmeadi Girault, G. capitatus Gahan, G. incomptus Huber e G. novifasciatus Girault) e por Zagella sp. (Trichogrammatidae) (Triapitsyn et al., 1998).

\subsubsection{Distribuição geográ fica}

Das espécies tratadas por Signoret, 320 ocorrem na América do Sul. Stål adicionou 14 e Fowler tratou o grupo integralmente em Biologia Centrali-Americana, descrevendo 138 espécies novas. Breddin e Jacobi também descreveram um número razoável de espécies da região andina e mais algumas outras dispersas, chegando a quase 500 espécies reconhecidas na região Neotropical, mostrando que essa é uma região muito rica em espécies de Cicadellinae (Osborn, 1926).

A distribuição geográfica dos Cicadellidae é dependente da distribuição das plantas hospedeiras, que exploram uma ampla variedade de espécies, em todas as regiões zoogeográficas. A maioria das espécies permanece restrita aos seus domínios zoogeográficos, mas algumas migram de seu provável local de origem, colonizando novas regiões. Muitas se estabelecem em plantas não relacionadas às hospedeiras originais e até tornam-se pragas de importância econômica (Nielson, 1985). Sabe-se que cada espécie tem uma ou mais plantas hospedeiras, onde os ovos são depositados e as formas jovens se desenvolvem, e várias plantas de alimentação, que servem apenas para manter as populações de adultos, não se prestando para reprodução (Menezes, 1972).

A distribuição é dependente dos hospedeiros, que são governados pelos fatores climáticos (latitude, altitude, temperatura, chuva, fotoperíodo) e pelos edáficos (Nielson, 1985).

As cigarrinhas da familia Cicadellidae são de origem tropical e apresentam um alto grau de plasticidade e adaptabilidade para uma ampla gama de plantas hospedeiras de todas as regiões zoogeográficas (Nielson, 1985). A distribuição espacial desses insetos nos pomares cítricos é geralmente agregada. Os adultos de Acrogonia sp. têm 
sido mais capturados na borda dos pomares, próximos às matas. Testes de livre escolha em casa de vegetação têm mostrado que $D$. costalimai e Oncometopia sp. podem alimentar-se em vários grupos de plantas, com preferência por espécies arbóreas ou arbustivas (Lopes, 1996b).

\subsection{8 Época de ocorrência}

Estudos de flutuação populacional de cigarrinhas em pomares de citros no Estado de São Paulo têm indicado um aumento da população em dezembro, com picos no verão e outono e decréscimo acentuado no período de agosto à novembro (inverno $\mathrm{e}$ primavera) (Paiva et al., 1996; Lopes, 1996b; Garcia Júnior et al., 1997).

Aparentemente, ocorrem condições desfavoráveis para o desenvolvimento das cigarrinhas em citros no final do inverno e início da primavera, acarretando mortalidade desses insetos e ou movimento para plantas hospedeiras alternativas em outros hábitats. Além da possível migração, esses insetos têm inimigos naturais eficientes, como himenópteros parasitóides de ovos e predadores de ninfas como as aranhas (Paiva et al., 1996).

\subsubsection{Importância econômica}

Muitas das espécies de Cicadellinae apresentam níveis populacionais elevados, quando infestam plantas de valor comercial e podem acarretar danos econômicos. Além disso, algumas espécies são importantes como possíveis transmissoras de doenças em plantas (Osborn, 1926).

Além dos prejuízos causados diretamente às plantas pela retirada de seiva, muitas espécies de cigarrinhas são toxicogênicas e outras vetores de fitoviroses (Zanol \& Menezes, 1982). A importância econômica é devida aos prejuízos diretos (sucção da seiva, oviposição e excreção) ou indiretos (toxinas salivares que alteram os tecidos vegetais e transmissão de viroses em plantas) (Menezes, 1972). 
Desde o primeiro relato da transmissão de patógenos por cicadelíneos, em 1942, encontra-se na literatura um número crescente de espécies consideradas vetoras de patógenos. (Nielson, 1968). No Brasil, nos últimos dez anos algumas espécies da subfamília Cicadellinae têm chamado atenção pela transmissão da bactéria $X$. fastidiosa em citros (Lopes, 1996a) e mais recentemente em cafeeiros (Paradela Filho et al., 1995). Reduzindo-se o número de cigarrinhas vetoras, não se reduz a incidência de infecção causada pela $X$. fastidiosa em uma tendência linear. Dessa forma, é muito difícil quantificar o dano indireto provocado por esses insetos (Purcell, 1994).

\subsection{A clorose variegada dos citros (CVC)}

A clorose variegada dos citros, recebeu a denominação popular de "amarelinho dos citros", por causar o aparecimento de pequenos frutos amarelos, sem valor comercial, nos ramos afetados das plantas. Está presente nos pomares do norte da Argentina (região de Montecarlo), desde 1984 (Coll, 1996). No Brasil, difundiu-se rapidamente no Estado de São Paulo, atingindo Minas Gerais, Rio de Janeiro e Paraná, e já foi constatada em Goiás, no Rio Grande do Sul e no Distrito Federal. É hoje a doença mais grave, que ameaça a citricultura brasileira (Tubelis et al., 1993). Ataca as principais variedades de laranja doce (Citrus sinensis L. Osbeck), independentemente do portaenxerto utilizado. Os limões verdadeiros, a lima-ácida 'Taiti' e as tangerinas em geral parecem ser tolerantes a essa doença. As plantas jovens são mais suscetíveis ao ataque de CVC, principalmente até a idade de sete anos (Garcia Júnior et al., 1995).

Pelo fato da doença ter surgido na área nuclear da citricultura brasileira, sua difusão está ocorrendo de maneira intensa. A citricultura paulista funciona como fornecedora de material de propagação para outras áreas do país e como conseqüência, a introdução de plantas doentes no sistema de produção de mudas provoca a difusão da doença para toda a citricultura brasileira. Já os insetos vetores estão envolvidos na sua difusão dentro dos pomares e entre pomares próximos (Tubelis et al., 1993). Ao adquirir a bactéria, os adultos podem transmití-la indefinidamente (Severin, 1949) e as ninfas perdem a habilidade em transmitir a bactéria após a ecdise (Purcell \& Finlay, 1979). 
Os ramos afetados pela bactéria têm obstrução nos vasos condutores de seiva para a parte aérea, gerando sintomas de murchamento. Como conseqüência, a planta perde parte da sua capacidade fotossintética em relação às sadias, fazendo com que haja uma baixa produção dessas árvores e seus frutos sejam miúdos (Garcia Júnior et al., 1995). Os estudos epidemiológicos indicam que o crescimento da incidência acompanha uma curva logística, com aumento inicial lento seguido de uma aceleração muito grande (Salva et al., 1995). A ocorrência de CVC geralmente é agregada e aumenta na primavera e verão (Laranjeira et al., 1998).

\subsubsection{A bactéria Xylella fastidiosa}

Xylella fastidiosa é uma bactéria gram-negativa, que mede 1 a $3,5 \mu \times 0,3$ a $0,5 \mu$ e cuja ocorrência é limitada ao xilema das plantas (Hopkins, 1988; De Negri \& Garcia Júnior, 1993). Além da CVC, existe um grande número de doenças causadas por linhagens dessa bactéria: a Pierce's disease na videira, o nanismo em alfafa, a queimadura de folha em amêndoa, phony peach em pessegueiro, a escaldadura de folhas em ameixeira (Purcell, 1980; French \& Feliciano, 1982; Hopkins, 1988), a escaldadura das folhas em cafeeiro (Paradela Filho et al., 1995). A mesma bactéria também pode causar doenças nas plantas daninhas assa-peixe (Vernonia sp.), agrião-do-brejo (Eclipta alba Hassk.), capim-carrapicho (Cenchrus echinatus L.), capim-favorito (Rhynchelitrum repens (Willd) C.E. Hubb), capim-pé-de-galinha (Eleusina indica (L.) Gaertn.), gramajesuíta (Axonopus compressus), grama-seda (Cynodon dactylon (L.) Pers.), guanxuma (Sida sp.), joá-bravo (Solanum sp.), poaia-branca (Richardia brasiliensis Gomez), e trapoeraba (Commelia benghalensis L.) (Travensolo \& Leite Jr, 1996). Podem também infectar plantas sem causar sintomas (Freitag, 1951; Brlansky et al.,1982; Raju et al., 1983) e provocar queimadura em olmo, carvalho, plátano e amoreira (Purcell, 1994).

Testes serológicos para detectar $X$. fastidiosa em plantas daninhas na Argentina, foram positivos para quatorze espécies (Coll et al.,1998a).

Uma característica particular da $X$. fastidiosa é que insetos vetores podem adquirí-la alimentando-se de várias espécies de plantas (Freitag, 1951). Muitas de suas 
estirpes são identificadas por suas atividades biológicas e outras podem replicar-se em várias hospedeiros (Derrick \& Beretta, 1996). Em função do grande número de hospedeiros e de espécies vetores, a epidemiologia da doença torna-se bastante complexa (Purcell, 1994). Acredita-se que a transmissão por vetores de todas as estirpes de $X$. fastidiosa, incluindo aquela que causa a clorose variegada dos citros, são similares para todas as espécies de vetores, mas isso ainda não foi confirmado (Purcell, 1996).

As cigarras (Cicadidae) e as cigarrinhas (Cercopidae e Cicadellidae, subfamília Cicadellinae e Evacanthinae) são sugadoras de xilema (White \& Strehl, 1978; Horsfield, 1978; Young, 1968; Nielson, 1985; Doling, 1991; Wilson \& Claridge, 1991). Portanto, podem adquirir a bactéria dos vasos colonizados, a qual adere às paredes internas do seu aparelho bucal (cibário, sulco apodemal do diafragma e nas áreas da parede do pré-cibário acima e abaixo da válvula) (Brlansky et al., 1983), podendo ser liberada em outras plantas nas futuras alimentações do inseto (Purcell, 1994).

A rápida dispersão de CVC no Brasil, sugere que a bactéria é facilmente transmitida por insetos vetores (Lopes et al., 1996). A eficiência de transmissão de $X$. fastidiosa pelas cinco espécies de cigarrinhas vetoras, em geral é baixa. As cigarrinhas da Tribo Cicadellini (D. costalimai, P. corniculata e B. xanthophis) parecem ser mais eficientes do que as da Tribo Proconiini (O. facialis e Acrogonia sp.) (Krügner et al., 1998).

$\mathrm{Na}$ Argentina, $X$. fastidiosa foi detectata pelo teste serológico nos cicadelídeos B xanthophis, Scopogonalia subolivacea (Stål), H. similis, Rotigonalia limbatula (Osborn), S. grossa, Chlorotettix latocinctus DeLong e Curtara samera DeLong \& Freytag (Coll et al., 1998a). 


\section{MATERIAL E MÉTODOS}

\subsection{Obtenção de amostras de cigarrinhas}

As coletas foram efetuadas na região de Bebedouro (SP), incluindo os municípios de Bebedouro e Monte Azul Paulista e o distrito de Turvínia, em pomares com 4 e 8 anos de idade, que possuíam alta população de cigarrinhas. Amostraram-se não somente as plantas cítricas (1.200 plantas de laranja 'Natal' e 3.000 plantas de laranja 'Hamlin'), mas também hábitats adjacentes variados - floresta hidrofólia, floresta estacional semi-decidual degradada, floresta estacional semi-decidual aluvial, cerrado, brejo, vegetação espontânea do pomar, capim-braquiária (Brachiaria decumbens Stapf) e culturas próximas (cafeeiros, cana-de-açúcar).

Os métodos utilizados na amostragem quinzenal foram: rede entomológica, cartões adesivos amarelos, succionador motorizado e armadilhas de Malaise.

As cigarrinhas foram coletadas pela Dra. Teresinha A. Giustolin, sob coordenação do Prof. Dr. Jõao Roberto Spotti Lopes como parte de um projeto desenvolvido entre o Departamento de Entomologia da ESALQ/USP e o Fundo Paulista de Defesa da Citricultura (Fundecitrus).

\subsubsection{Rede entomológica}

As cigarrinhas foram coletadas em ramos novos de laranjeiras e cafeeiros com rede entomológica ( 4 batidas/quadrante/planta, em 50 plantas). $\mathrm{O}$ material coletado foi etiquetado e conservado em frascos contendo álcool $70 \%$, para posterior triagem em laboratório. 


\subsubsection{Cartões adesivos amarelos}

Como armadilhas adesivas foram utilizados cartões retangulares amarelos $(7,5$ X $12 \mathrm{~cm}$ ) contendo cola (Olson Products $(\circledR)$, posicionados nas plantas a $1,80 \mathrm{~m}$ do solo e aproximadamente $40 \mathrm{~m}$ entre plantas. As armadilhas recolhidas no campo foram encaminhadas ao laboratório, onde procedeu-se à remoção das espécies, utilizando-se querosene como solvente da cola e separação do material, que foi etiquetado e conservado em frascos contendo álcool $70 \%$, para posterior identificação.

\subsubsection{Succionador motorizado}

Foi empregado um equipamento de sucção motorizada portátil, que aspira os insetos nos brotos novos da laranjeira e do cafeeiro até uma altura aproximada de $1,5 \mathrm{~m}$ (sucção de 20 plantas), aprisionando os insetos numa rede de voil. $\mathrm{Na}$ vegetação espontânea e no capim-braquiária a sucção foi feita por um período de $1 \mathrm{~min} / \mathrm{amostra}$ $(n=10)$. O material coletado foi enviado ao laboratório, onde fez-se separação, etiquetagem e conservação em frascos contendo álcool $70 \%$, para posterior identificação.

\subsubsection{Armadilhas de Malaise}

Foram instaladas armadilhas de Malaise ( 6 X 2 X 2,5 m) contendo 2 frascos de coleta com inseticida Diclorvos (Revenge $(\mathbb{R})$, na porção central de dois pomares de laranja, no cafezal, na floresta estacional semi-decidual aluvial e na floresta hidrofólia. $O$ material coletado foi encaminhado ao laboratório em sacos plásticos, onde procedeu-se à separação, a etiquetagem e a conservação em frascos contendo álcool $70 \%$, para posterior identificação. 


\section{2 Obtenção de ninfas}

As ninfas foram obtidas de uma criação realizada no Departamento de Entomologia da ESALQ/USP. Para obtenção de ovos, os adultos (machos e fềmeas) de Acrogonia sp., Oncometopia facialis e Dilobopterus costalimai coletados em citros no município de Cordeirópolis (SP), e confinados sobre mudas envasadas de laranja doce (Citrus sinensis L. Osbeck) através de cilindros de plástico transparente de $10 \mathrm{~cm}$ de diâmetro, contendo abertura nas laterais e no topo cobertas com voil para ventilação. As plantas foram inspecionadas diariamente quanto à presença de ovos. As folhas contendo posturas foram retiradas das plantas e colocadas em uma placa de Petri, com o pecíolo envolvido em um chumaço de algodão umedecido para manutenção da turgescência da folha. As placas foram imediatamente levadas para uma incubadora do tipo B.O.D com temperatura de $25 \pm 2^{0} \mathrm{C}$, sendo diariamente avaliadas quanto à eclosão de ninfas. As ninfas recém-eclodidas foram retiradas das placas de Petri e confinadas (individualmente) nas brotações novas de mudas de laranja envasadas (40-60 $\mathrm{cm}$ de altura). Para o confinamento, utilizaram-se caixas plásticas retangulares $(54 \times 42 \times 12 \mathrm{~mm})$ e transparentes, providas de aberturas circulares cobertas com voil, para permitir a ventilação. Avaliou-se as ninfas diariamente quanto à mudança de ínstar $\mathrm{e}$ sobrevivência, separando-se as mortas de cada ínstar por meio de um pincel fino molhado em água.

\subsection{Montagem do material}

Os exemplares adultos, previamente conservados em álcool $70 \%$, foram montados em alfinetes entomológicos após serem secos em papel de filtro. Em alguns casos, utilizou-se montagem dupla.

Para os estudos morfológicos, optou-se por utilizar primeiramente os exemplares adultos coletados em rede entomológica ou succionador motorizado, que se encontravam em melhores condições do que aqueles coletados em cartões adesivos. As 
ninfas de diferentes idades foram fixadas em álcool etílico $70 \%$, sendo a descrição referente à coloração das ninfas conservadas em álcool.

Os exemplares (adultos e ninfas) foram depositados na coleção do Departamento de Entomologia da ESALQ/USP, em Piracicaba, SP.

\subsection{Método de preparação das estruturas da genitália}

Para a identificação das espécies, procedeu-se ao estudo da genitália do macho, baseando-se nos trabalhos de Young (1968 e 1977). A genitália foi preparada utilizando-se o seguinte procedimento:

a) remoção do abdome inteiro, com auxílio de estiletes;

b) tratamento com solução de hidróxido de sódio $(\mathrm{NaOH})$ a $10 \%$ aquecida à ebulição, durante 3 a 5 minutos, de acordo com o tamanho do exemplar, ou tratamento com $\mathrm{NaOH}$ a $20 \%$ a frio, durante 12 a 24 horas;

c) lavagem do abdome com água destilada durante cerca de 10 minutos, procurando-se separar a cápsula genital do resto do abdome;

d) passagem da cápsula genital e do resto do abdome para uma lâmina com glicerina e observação em microscópio estereoscópico. Com auxílio de estiletes com pontas bem finas e recurvadas, foi retirada numa só peça, a genitália interna do inseto (o edeago, o conectivo e os dois estilos).

Posteriormente as peças genitais e o abdome do inseto foram guardados em glicerina, em pequenos tubos de polietileno, cuja tampa foi atravessada pelo mesmo alfinete com o restante do inseto.

\subsection{Caracterização morfológica}

A caracterização de adultos foi baseada nos caracteres taxonômicos mencionados por Young (1968 e 1977), Menezes (1972), Blocker \& Triplehorn (1985) e Nielson (1985). Foi elaborada uma chave para a identificação das principais espécies de cigarrinhas coletadas em citros na região de Bebedouro (SP). Para descrição das formas 
imaturas, foi utilizada a terminologia adotada por Cavichioli (1987) e Wilson \& Claridge (1991). Elaborou-se um glossário com a terminologia usada, sendo que algumas estruturas do corpo estão ilustradas na Figura 1.

As sinonímias foram omitidas, visto que se encontram nos trabalhos de Metcalf (1965) e Young (1968 e 1977).

\subsection{Ilustrações e medições}

As ilustrações foram realizadas pela Bióloga Patrícia Milano, com auxílio de câmara-clara para microscópio estereoscópico. As estruturas genitais e as asas foram preparadas em lâminas com glicerina. Colocou-se as asas entre lâmina e lamínula. e depois de desenhadas, foram colocadas junto ao inseto em um triângulo de cartolina fixado no alfinete de montagem.

As medições das ninfas foram feitas por meio de um retículo micrométrico acoplado a um estereomicroscópio. As medidas foram expressas em milímetros, correspondendo à média, desvio padrão e respectivas amplitudes de 10 ninfas, para cada um dos estágios, com exceção de alguns estágios, em que havia um número menor de exemplares. Nas ninfas foram medidos comprimento total do corpo (do ápice da cabeça até a extremidade do abdome), da cabeça (linha mediana), da cabeça-tórax (linha mediana); largura da cabeça e do pronoto.

\subsection{Terminologia}

\section{Cabeça:}

- Coroa: superfície dorsal da cabeça, entre os olhos.

- Face: porção ântero-ventral da cabeça, formada por vários escleritos, mais ou menos fundidos entre si. A porção central consta de dois escleritos, um superior completamente fundido à fronte, o clípeo (posclípeo) e um inferior, menor e alargado em cima separados pela sutura clipeal, o clipelo (anteclípeo). O clípeo é limitado lateralmente 
pelas suturas frontais laterais e, superiormente, pela sutura pós-frontal. Os músculos dilatadores do cibário são fixados em sua superfície interna.

- Lóbulos suprantenais: locais onde as antenas se inserem, junto aos ângulos oculares anteriores.

\section{Tórax:}

- Epimero: área da pleura posterior em direção a sutura pleural dividida horizontalmente em proepímero, mesepímero e metepímero.

- Episterno (proepisterno): área da pleura antes da sutura pleural e acima do trocânter, algumas vezes dividido horizontalmente em anepisterno, catepisterno e metepisterno.

- Meron: área lateral articular da base da coxa, grandemente alargada e estendendo-se distalmente na porção posterior da coxa.

- Superfície plantar: esclerito mediano ventral que se estende da porção distal do prétarso até as garras.

- Nervura $R_{2+3}$ : nervura presente nas asas posteriores, podendo ser interrompida ou não.

- Células apicais e anteapicais (pré-apicais): células delimitadas pelas nervuras radiais, medianas e cubitais.

- Fórmula setal: o arranjo setal do fềmur posterior é expresso pela fórmula 2.0.0 (cerdas apicais pareadas sem cerdas próximas); 2.1.0 (par de cerdas apicais e uma mais próxima); 2.1 .1 (cerdas apicais pareadas e duas arranjadas em série); 2.1.1.1 (par de cerdas apicais e três arranjadas em série).

\section{Genitália masculina:}

- Pigóforo: cápsula genital formada pelo nono tergito, escavado dorsalmente para incluir o tubo anal, formado pelos dois últimos segmentos abdominais.

- Placas subgenitais: par de placas ou expansões laterais do pigóforo, que juntamente com a valva basal fecham-no ventralmente; protegem o edeago e acionam os órgãos acessórios de acoplamento.

- Edeago (pênis): órgão intromitente, constituindo-se no caráter mais importante para a identificação. É formado pela base, geralmente robusta e pela haste, mais longa e fina, 
no interior da qual está o gonoduto, que se abre no gonóporo, geralmente situado na porção apical da haste. $O$ edeago pode ser simétrico ou assimétrico. Processos podem originar-se em qualquer porção do edeago.

-Fragma: estrutura mais ou menos membranosa que sustenta o edeago dorsalmente entre o tubo anal e o pigóforo.

- Conectivo: parte basal do edeago, podendo apresentar as formas de Y, T ou linear.

- Estilos ou parâmeros: estruturas pareadas simétricas essenciais para o acoplamento por ocasião da cópula; fundidos lateralmente às placas genitais e articulados pelo braço ventral ao conectivo.

- Paráfises: estruturas acessórias que ocorrem entre o conectivo e a base do edeago, pareadas ou não. Ocorrem quando o edeago perde a ligação estreita com o conectivo e o fragma liga-se ao pigóforo dorsalmente.

- Macrocerda: cerda espessa e grande.

- Microcerda: cerda fina e pequena.

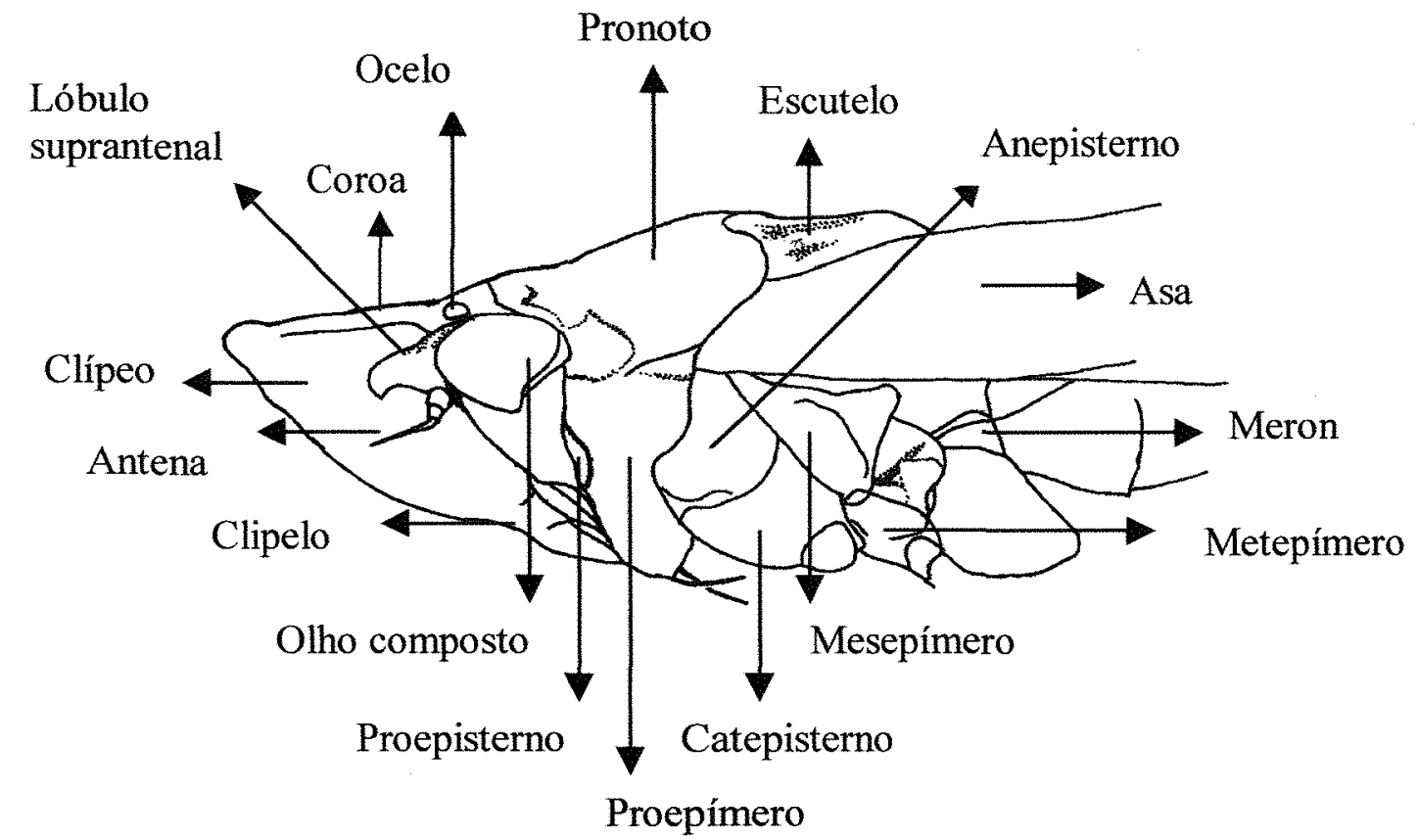

Figura 1 - Acrogonia sp. Cabeça, pronoto e escutelo (vista lateral). 


\section{RESULTADOS E DISCUSSÃo}

\subsection{Adultos}

Nos levantamentos de cigarrinhas realizados em pomares cítricos da região norte do Estado de São Paulo, várias espécies pertencentes à família Cicadellidae foram coletadas, no entanto, selecionaram-se algumas mais comuns pertencentes à subfamília Cicadellinae. A identificação das cigarrinhas foi confirmada pelo Prof. Dr. Rodney Ramiro Cavichioli da Universidade Federal do Paraná e pelo Prof. Gabriel Luis F. Mejdalani do Museu Nacional e da Universidade Federal do Rio de Janeiro. As espécies, em que houve dúvidas quanto a identificação, não foram incluídas neste trabalho. Os cicadelíneos selecionados para este trabalho encontram-se listados a seguir:

\section{Tribo Cicadellini}

1 - Bucephalogonia xanthophis (Berg, 1879)

2 - Dilobopterus costalimai Young, 1977

3 - Ferrariana trivittata (Signoret, 1854)

4 - Hortensia similis (Walker, 1851)

5 - Macugonalia cavifrons (Stål, 1862)

6 - Macugonalia leucomelas (Walker, 1851)

7 - Oragua triplehorni Young, 1977

8 - Parathona gratiosa (Blanchard, 1840)

9 - Plesiommata corniculata Young, 1977

10- Plesiommata mollicella (Fowler, 1900)

11 - Sonesimia grossa (Signoret, 1854) 


\section{Tribo Proconiini}

12 - Acrogonia sp.

13 - Acrogonia virescens (Metcalf, 1949)

14 - Homalodisca ignorata Melichar, 1924

15 - Oncometopia facialis (Signoret, 1854)

16 - Teletusa limpida (Signoret, 1855

Destas, dez espécies mais comuns (duas da tribo Proconiini e oito da tribo Cicadellini) foram caracterizadas. Em Proconiini, as espécies dos gênero Oncometopia e Homalodisca, não podem ser identificadas com base nos caracteres externos (item 4.1.1.1) e, em Cicadellini as espécies dos gêneros Oragua, Ferrariana, Hortensia, Dilobopterus e Plesiommata não podem ser distintas pelos caracteres externos (item 4.1.1.3), mas as do gênero Macugonalia podem ser identificadas pela morfologia externa.

\subsubsection{Chave para as tribos de Cicadellinae}

-Pernas posteriores, em repouso, com a junção fềmur-tíbia não atingindo a margem posterior do proepímero; lóbulo suprantenal protuberante em vista dorsal; (Fig. 2) pronoto geralmente rugoso e pubescente; pigóforo e placas subgenitais do macho usualmente com numerosas microcerdas dispersas (ocasionalmente com poucas macrocerdas intercaladas); espécies robustas.......................................................Proconiini

-Pernas posteriores, em repouso, com a junção fềmur-tíbia atingindo a margem posterior do proepímero; lóbulo suprantenal não protuberante em vista dorsal; (Fig. 3) pronoto com superficie lisa; pigóforo e placas subgenitais usualmente com numerosas macrocerdas dispersas (eventualmente com poucas microcerdas); espécies de menor porte. Cicadellini 


\subsubsection{Chave para os gêneros e espécies de Proconiini, com base em caracteres externos}

1. Superficie do corpo pubescente; espécies de coloração escura. 2

Superficie do corpo sem pubescência; espécies alongadas. 4

2. Perna anterior com a tíbia expandida e achatada no ápice (Fig. 4A); cabeça, face escutelo com densa área pubescente (Fig. 4B e 4C); olhos proeminentes; antenas excessivamente grandes; asas anteriores hialinas levemente enfumaçadas próximo as bordas; acentuada variação de cor e tamanho entre machos e fềmeas .Teletusa limpida

Perna anterior com tíbias normais ou levemente dilatadas. .3

3. Clípeo dilatado, convexo, não-achatado e nem côncavo medianamente, com granulações entre as impressões musculares de cada lado do clípeo e manchas escuras nos lados superior e inferior da cabeça (Fig. 16A).............................. Oncometopia sp. Clípeo levemente achatado medianamente ou deprimido, sem granulações entre as impressões musculares de cada lado do clípeo; coroa longa, margem anterior angulosa (Fig. 5 A e 5B).

Homalodisca sp.

4. Cabeça, pronoto e escutelo de coloração escura manchado de amarelo (Fig. 10A) Acrogonia sp.

Cabeça, pronoto e escutelo sem manchas amarelas (Fig. 6 A e 6B); coloração dorsal variável desde diferentes tons de verde até amarelo-amarronzado e a ventral principalmente amarela; mancha na forma de $U$ no ápice da cabeça; algumas espécies com o clípeo e a linha mediana do clipelo sombreados de preto; fềmeas mais robustas que os machos. Acrogonia virescens 

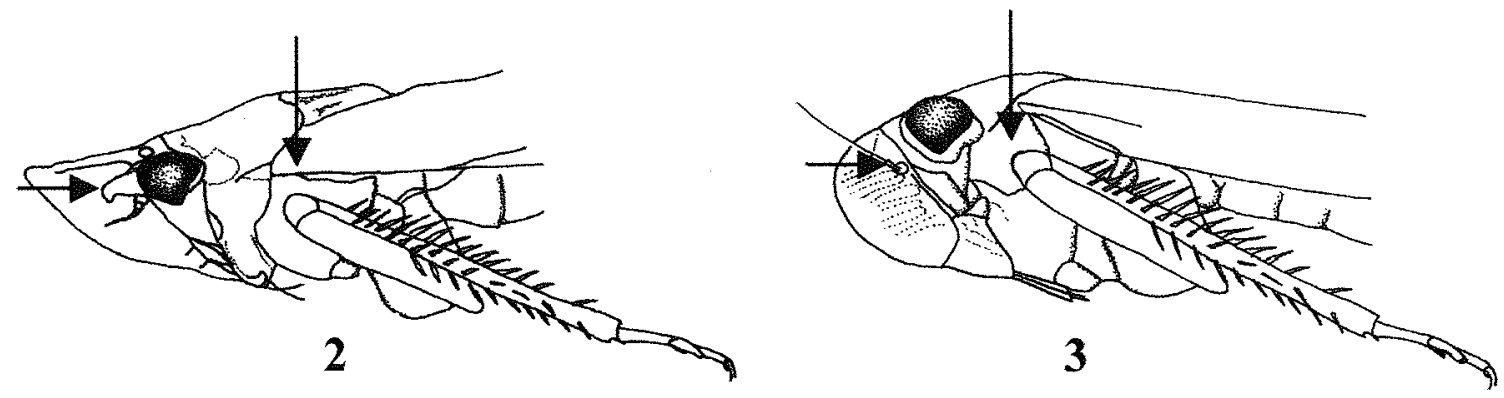

Figura 2 - Acrogonia sp. (junção fềmur-tíbia não atingindo a margem posterior do proepímero).

Figura 3 - Dilobopterus costalimai (junção fềmur-tíbia atingindo a margem posterior do proepímero).
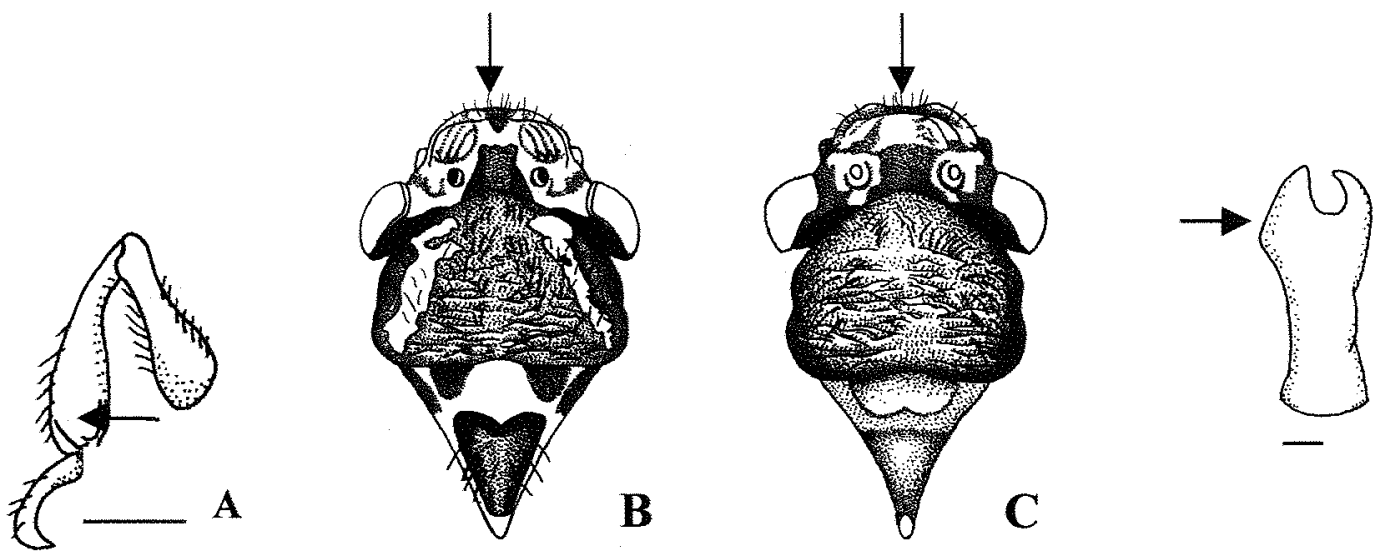

A

B

C

D

Figura 4 - Teletusa limpida. (A) tíbia anterior (vista lateral); (B e C) cabeça pronoto e escutelo de fềmea e macho (vista dorsal); (D) edeago (vista ventral) (escala A: $1 \mathrm{~mm}$; B e C: $0,4 \mathrm{~mm}$; D: $0,1 \mathrm{~mm}$ ). 


\subsubsection{Chave para as espécies de Proconiini, com base nas estruturas genitais do macho}

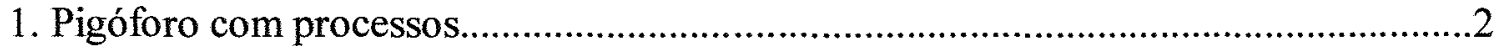

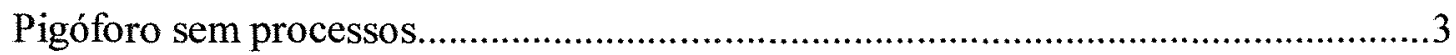

2. Edeago assimétrico com uma série de processos dispostos irregularmente (Fig. 16D e $16 \mathrm{~F})$ Oncometopia facialis

Edeago simétrico com um par de processos ventrais e a haste curvada dorsalmente (Fig. 5C) Homalodisca ignorata

3. Tubo anal com processos (Fig. 6C); conectivo em Y; estilo alongado, fino, curvado internamente e em forma de gancho no ápice (Fig. 6D); haste do edeago alongada com o ápice fino e pontiagudo; área basal na forma de um $\mathrm{Y}$ (Fig. 6E) Acrogonia virescens

Tubo anal sem processos .4

4. Conectivo em Y; edeago simétrico, levemente alargado no ápice e sem processos (Fig. 4D). Teletusa limpida

Conectivo linear (Fig. 10F); edeago, curvo, bífido em quase toda a extensão; margem ventral sem concavidade ou convexidade na base, em vista lateral (Fig. 10G) Acrogonia sp.

\subsubsection{Chave para os gêneros e espécies de Cicadellini com base em caracteres externos}

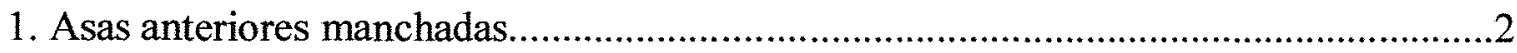

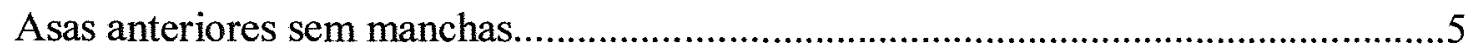




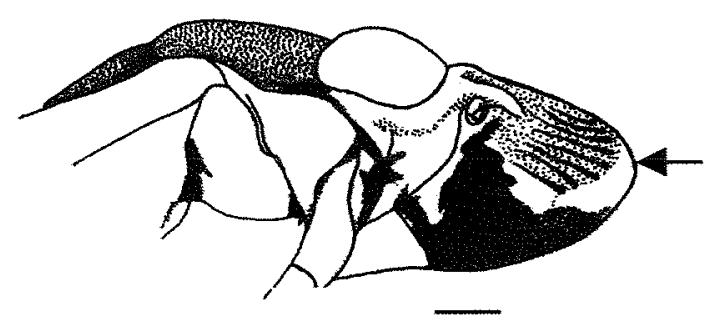

A

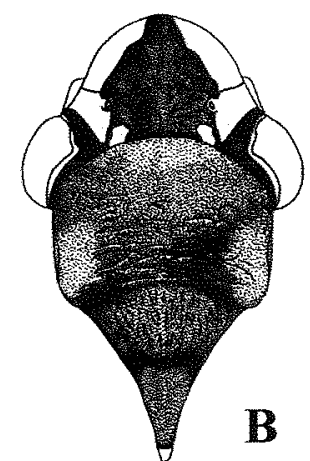

B

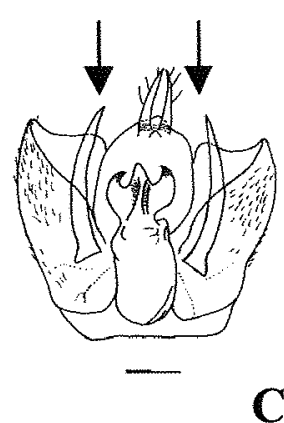

C

Figura 5 - Homalodisca ignorata. (A e B) cabeça, pronoto e escutelo (vista lateral e dorsal); (C): pigóforo e edeago (vista ventral) (escala A e C: $0,5 \mathrm{~mm}$; B: 0,4 $\mathrm{mm})$.

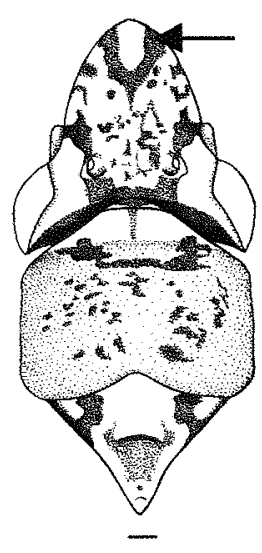

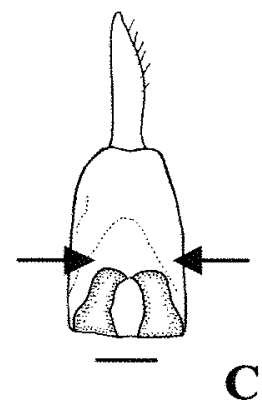

$\mathbf{A}$

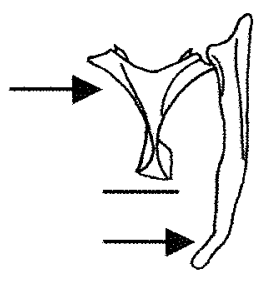

D

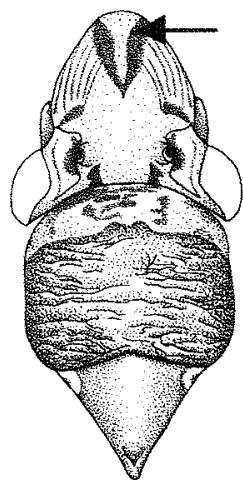

B

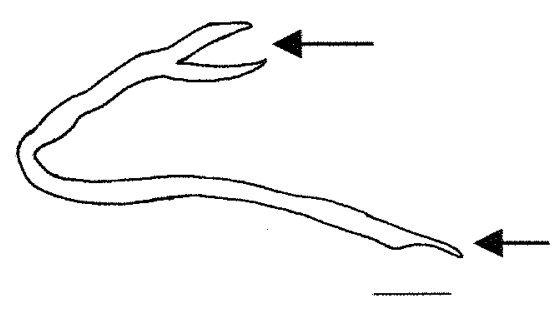

$\mathbf{E}$

Figura 6 - Acrogonia virescens. (A e B) cabeça, pronoto e escutelo de fềmea e macho (vista dorsal); (C) tubo anal (vista ventral); (D) conectivo e estilo (vista dorsal); (E) edeago (vista lateral) (escala A e B: $0,25 \mathrm{~mm}$; C, D e E: 0,32 $\mathrm{mm})$. 
2. Asas anteriores com a área manchada opaca, delimitada por uma porção membranosa 3

Asas anteriores com pequenas máculas pálidas em quase toda a extensão (Fig. 7A); com uma série de pontuações na superfície dorsal (cabeça, pronoto e escutelo) (Fig. 7B). Oragua sp.

3. Asas anteriores com pequenas máculas em toda parte da área opaca (Fig. 8A e 15B)

Asas anteriores com poucas pequenas máculas e duas manchas largas, distintas e pálidas (Fig. 15F) Macugonalia leucomelas

4. Asas anteriores com numerosas pequenas manchas amarelas, verde ou azuis arranjadas em série e com uma distinta mancha grande arredondada, amarela situada próxima ao ápice do clavo (Fig. 8A); cabeça amarela-alaranjada com algumas linhas pretas; ocelos localizados atrás da linha imaginária que tangencia os ângulos oculares anteriores; pronoto com duas linhas pretas próximas e duas de cada lado (Fig. 8B); clípeo pálido, sem manchas amarelas Parathona gratiosa Asas anteriores manchadas em toda área opaca (Fig. 15B), seguindo o mesmo padrão da cabeça e tórax (Fig. 15A); face com muitas manchas escuras no disco do clípeo, e somente uma área amarelada central não-manchada. Macugonalia cavifrons

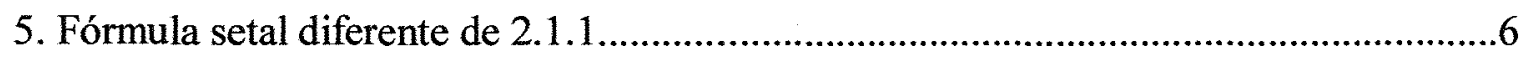

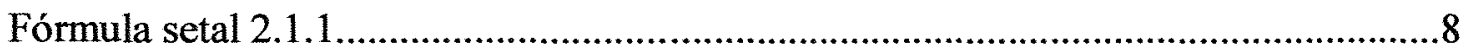




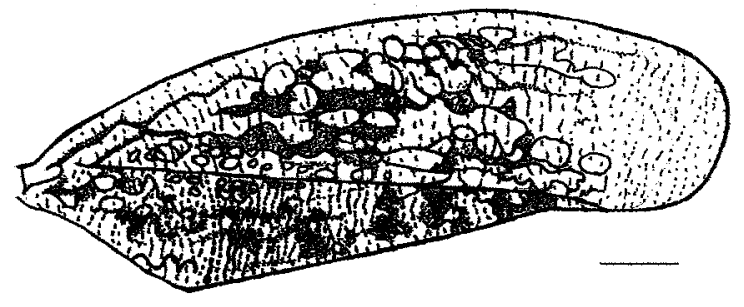

C

$\frac{1}{9}$

A

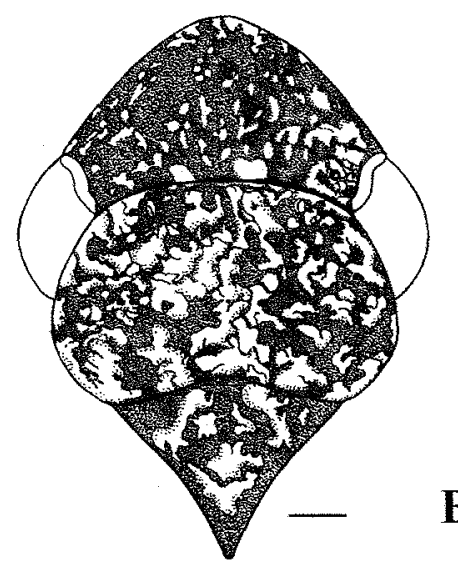

B

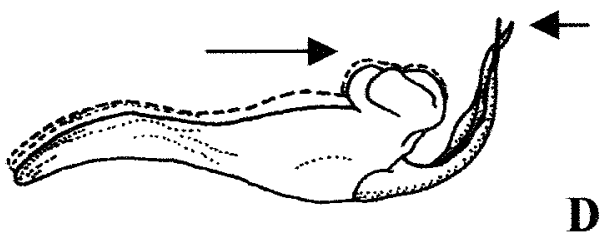

Figura 7. - Oragua triplehorni. (A) asa anterior; (B) cabeça, pronoto e escutelo (vista dorsal); (C) processos anteapicais do edeago (vista ventral); (D) edeago (vista lateral) (escala A: 0,4 mm; B: 0,32 mm; C: 0,1 mm; D: 0,25 mm).
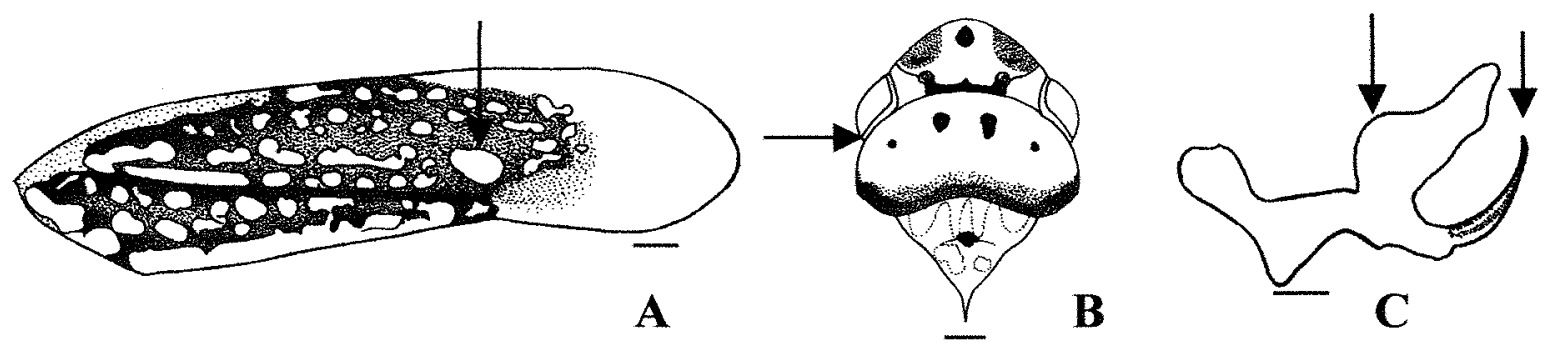

Figura 8 - Parathona gratiosa. (A) asa anterior; (B) cabeça, pronoto e escutelo (vista dorsal); (C): edeago (vista lateral) (escala A e B: 0,4 mm; C: 0,16 mm). 
6. Asas anteriores com a área anterior opaca, delimitada por uma membrana incluindo células apicais e parcialmente células anteapicais (Fig. 11C)........................................ Asas anteriores com nervuras claras e salientes; largura transocular da cabeça maior que a largura do pronoto; cabeça, pronoto e escutelo com duas faixas longitudinais pretas, que quase se encontram no ápice da cabeça (Fig. 9A) Sonesimia grossa

7. Coloração variando de amarelo a verde, com ou sem conspícuas manchas escuras na coroa (Fig. 11A e 11B). Bucephalogonia xanthophis

Coloração não-esverdeada; face clara com uma linha mediana escura, estendendo-se sobre o clípeo e a porção anterior do clipelo; fêmur com uma série de microcerdas. Sonesimia grossa

8. Asas anteriores com nervuras distintas ou não na área opaca. Asas anteriores praticamente hialinas, com nervuras salientes ou distintas (Fig. 17B)

9. Asas anteriores com faixas longitudinais contrastantes (Fig. 13B); coroa com uma faixa de cor laranja ou vermelha, próxima à margem anterior (Fig. 13A). Ferrariana sp.

Asas anteriores com uma área opaca esverdeada, delimitada por uma membrana, incluindo as células apicais; coroa e porção anterior do pronoto com uma série de manchas lineares escuras (Fig. 14A) Hortensia sp.

10. Asas posteriores com um conspícuo lobo jugal alargado (Fig. 12C); coloração amarela ou alaranjada, com uma série de faixas pretas, formando desenhos característicos na cabeça, tórax e escutelo (Fig.12A) Dilobopterus sp. Asas posteriores sem lobo jugal alargado; cabeça com mancha preta de formas variáveis entre a porção mediana da coroa e o ápice; ocelos podem estar delimitados em uma área de coloração escura (Fig.17A e 17G) Plesiommata sp. 

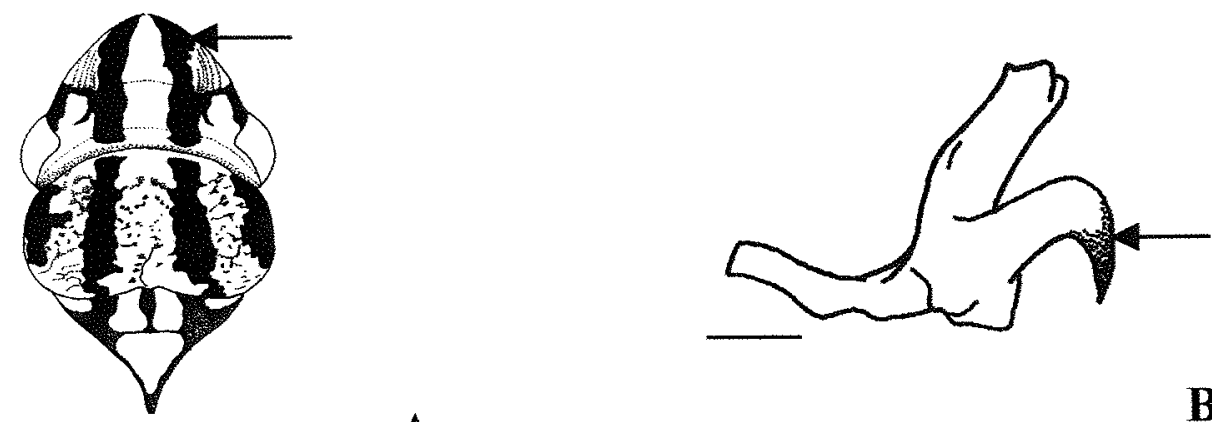

A

B

Figura 9 - Sonesimia grossa. (A) cabeça, pronoto e escutelo (vista dorsal); (B) edeago (vista lateral) (escala: A: $0,4 \mathrm{~mm}, \mathrm{~B}: 0,5 \mathrm{~mm}$ ).

\subsubsection{Chave para os gêneros e espécies de Cicadellini com base nas estruturas genitais dos machos}

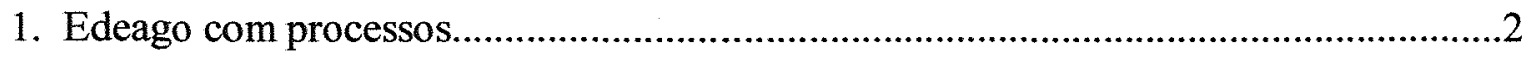

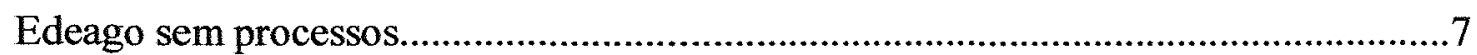

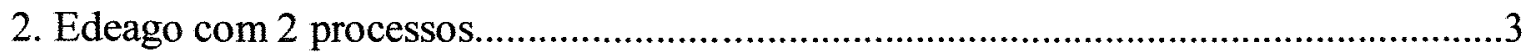

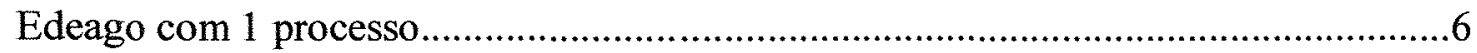

3. Edeago pequeno com um par de processos na base (vista ventral)..............................4 Edeago com um par de pequenos processos anteapicais (Fig. 7C) e um par de longas apódemas estendendo-se anteriormente; haste curvada dorsalmente (Fig. 7D) Oragua triplehorni

4. Edeago convexo dorsalmente (Fig. 15D e 15H) Macugonalia sp.

Edeago com expansões na haste, em vista lateral. .5

5. Edeago pequeno com a haste, em vista lateral, bastante expandida no ápice (Fig. 17F); em vista ventral se assemelha a uma taça. (Fig. 17E). Plesiommata corniculata 
Edeago pequeno com a haste, em vista lateral, com uma expansão dorsal de cada lado, próximo ao comprimento mediano (Fig. 17H e 17I)........Plesiommata mollicella

6. Edeago com um processo surgindo na base (vista ventral), curvado gradualmente na direção ventral (Fig. 9B)................................................................... Sonesimia grossa Edeago com um simples processo pontiagudo no ápice, curvado gradualmente na direção dorsal; haste alargada, em vista lateral, e convexa no ápice (Fig. 8C) Parathona gratiosa

7. Conectivo em $\mathrm{Y}$ .8

Conectivo em T (Fig. 11G ); edeago pequeno, curvado dorsalmente na metade apical (vista lateral) (Fig. 11H e 11I). Bucephalogonia xanthophis

8. Paráfises presentes. 9

Paráfises ausentes; edeago em vista lateral, com a haste não abruptamente alargada no ápice (Fig. 14 D e 14 E). Hortensia similis

9. Paráfises simétricas (pareadas), dispostas em dois ramos (Fig. 13D); edeago com a haste reta (Fig. 13F); apódemas basais tão longos quanto a haste do edeago. Ferrariana trivittata Paráfise assimétrica (não-pareada) consistindo de um fino ramo que se alarga próximo a base, podendo apresentar o ápice denteado (Fig. 12H); pigóforo com dois pequenos processos apicais, em vista dorsal (Fig. 12D ); edeago com um conspícuo lobo, estendendo-se posteriormente, redondo apicalmente, levemente separado da haste (Fig. 12G) Dilobopterus costalimai 


\subsubsection{Caracterização das espécies de cigarrinhas mais comuns nos pomares de citros amostrados}

\section{Acrogonia sp.}

Cabeça: Triangular, alongada; ápice levemente curvado dorsalmente; coloração preta manchada irregularmente com amarelo (Fig 10A e 10B); clípeo convexo e levemente dilatado na base; ocelos localizados mais próximos aos olhos que entre si e atrás da linha imaginária que tangencia os ângulos oculares anteriores; lóbulos suprantenais salientes em vista dorsal; impressões musculares bastante evidentes; face amarelada com as bordas mais escuras.

Tórax: Largura do pronoto menor do que a largura transocular da cabeça; coloração preta, com a porção anterior do pronoto e escutelo manchado de amarelo e o restante de azul-amarelado ou verde; asas anteriores hialinas, com poucas áreas opacas e nervuras elevadas ou proeminentes, em posição de repouso expõe o meron e cobre o ovipositor das fềmeas (Fig. 10C); asas posteriores com a nervura $R_{2+3}$ interrompida (Fig. 10D); ausência de pubescência; pernas de coloração amarela; pernas posteriores com o comprimento do basitarso maior do que a soma do comprimento dos distais.

Genitália do macho: Pigóforo de coloração avermelhada e muito longo, excedendo o ápice das asas quando em posição de repouso; ausência de processos no pigóforo; placas subgenitais finas e longas (Fig. 10E); edeago curvo (vista lateral), com a margem ventral sem concavidade ou convexidade na base e bífido em quase toda sua extensão (Fig.10G); conectivo linear, longo e fino; estilos não-truncados apicalmente, com uma pequena modificação no ápice na forma de um gancho (vista ventral), estendendo-se posteriormente ao ápice do conectivo (Fig. 10F); ausência de paráfises.

Comprimento: Machos:9,77 mm $\pm 0,44$ (9,0-10,0 mm). Fêmeas: 10,25 mm $\pm 0,42(10,0-$ $11,0 \mathrm{~mm})$.

Diagnose: Ápice da cabeça levemente curvado, em vista lateral; superfície dorsal da cabeça, pronoto e escutelo manchada de amarelo e azul-amarelado; edeago bífido e curvo. 
Nota Taxonômica: Essa espécie de Acrogonia apresenta a genitália do macho semelhante a de $A$. gracilis (Osborn, 1926), porém não possue uma reentrância ventrobasal (margem ventral côncava basalmente) no edeago, como observado nas ilustrações de Young (1968). Ao descrever a espécie A. gracilis, Osborn utilizou uma fêmea como se fosse macho, devido ao esternito VII bipartido, característica da placa subgenital dos machos. Young (1968) comparou exemplares machos com o holótipo (fềmea) e descreveu o macho.

Distribuição Geográfica: O gênero Acrogonia estende-se da América Central para o sul do Brasil e Bolívia (Young, 1968).

Hospedeiros: Citros (Citrus sinensis L. Osbeck) e vegetação adjacente ao pomar.

Material: BRASIL São Paulo: Bebedouro, 04/VII/1997 (R. Krügner), 1 fềmea (ESALQ); III/1998 (S. Roberto), 1macho e 2 fềmeas (ESALQ); 09/VII/1997 (R. Krügner), 1 macho e 6 fềmeas (ESALQ); 14/V/1998 (S. Roberto), 1 fềmea (ESALQ); IV/1998 (S. Roberto), 2 machos (ESALQ); 16/VII/1998 (R. Krügner), 8 machos (ESALQ); Turvínia, 03/VII/19971 (T. A. Giustolin), 1 fềmea (ESALQ); 03/VII/1997 (T. A. Giustolin), 1 macho (ESALQ); Monte Azul Paulista, 06/VI/1998 (R. Krügner), 6 machos (ESALQ); Mato Grosso: Anastácio, 27/11/1997 (C.M. Oliveira), 1 macho (ESALQ).

Comentários: O gênero Acrogonia apresenta grande variação intra-específica na coloração e o ápice da cabeça levemente curvado dorsalmente. Não se conhece nenhuma relação com outro gênero (Young, 1968), no entanto, há muita dificuldade na identificação específica, havendo necessidade, talvez de uma revisão genérica. Predominantemente, localizam-se nas folhas em sua parte superior, tendo preferência pelas mais tenras de coloração verde-clara, sugando preferencialmente as nervuras das folhas. Seus ovos são depositados sobre as folhas maduras, em ambas as faces, com predominância na inferior. São alongados e dispostos lado a lado em forma de pente e em duas camadas (Yamamato \& Roberto, 1997). Observações de campo têm demonstrado que a postura de Acrogonia sp. não é endofítica. As fêmeas são semelhantes aos machos, apenas de tamanho maior e cobrem os ovos com uma substância branca, excretada provavelmente pelos tubos de Malpighi, podendo 
apresentar duas manchas brancas convexas e esféricas de brocossomos nas asas anteriores e a terceira fileira de espinhos das tíbias posteriores bastante desenvolvida. As fêmeas do gênero Acrogonia têm os mais especializados brocossomos e provavelmente este desenvolvimento incomum da quetotaxia metatibial está relacionado com seu comportamento incomum de oviposição (Rakitov ${ }^{1}$ ). Essa espécie é uma das mais constantes em pomares cítricos, floresta hidrofólia, brejo e cerrado), sendo coletada praticamente em todas as avaliações nos diferentes hábitats.

\section{Bucephalogonia xanthophis (Berg, 1879)}

Cabeça: Moderadamente produzida; com uma variação de cor muito grande (desde manchas conspícuas pretas até total ausência dessas); margem anterior redonda em vista dorsal; ocelos localizados muito mais próximos dos olhos que da linha mediana da coroa e na linha imaginária entre os ângulos oculares anteriores (Fig. 11A e 11B); coroa convexa; sutura lateral do clípeo estendendo-se sobre a coroa e atingindo os ocelos; clípeo convexo; impressões musculares distintas; face sem pubescência; coroa com uma série de pontuações.

Tórax: Largura do pronoto menor que a largura transocular da cabeça; pronoto nãorugoso; asas anteriores com a maior área translúcida ou opaca pontuada (pigmentada de verde até na extremidade do clavo), delimitada por uma membrana pontiaguda (margem apical convexa), incluindo as células apicais, parcialmente as células anteapicais e uma área ao longo da margem costal, nervuras distintas, em posição de repouso ultrapassando o ápice do ovipositor (Fig. 11C); asas posteriores com a célula apical externa alargada e quase tocando a margem costal, com a nervura $R_{2+3}$ ausente (Fig. 11D); fórmula setal 2.1.0; comprimento do basitarso bastante semelhante ao comprimento dos distais, com duas fileiras paralelas de cerdas na superfície plantar.

Genitália do macho: Pigóforo moderadamente produzido, truncado no ápice; placas subgenitais alargadas na base, reduzindo-se abruptamente antes da porção mediana, com

\footnotetext{
${ }^{1}$ RAKITOV, R. Comunicação pessoal, 1998.
} 


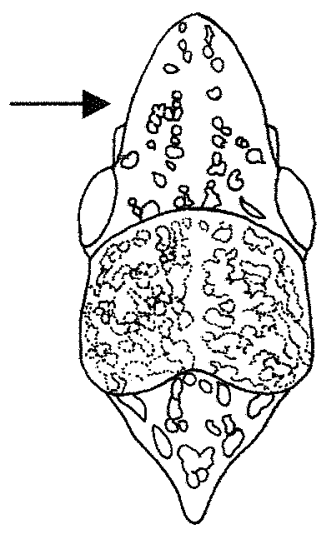

A
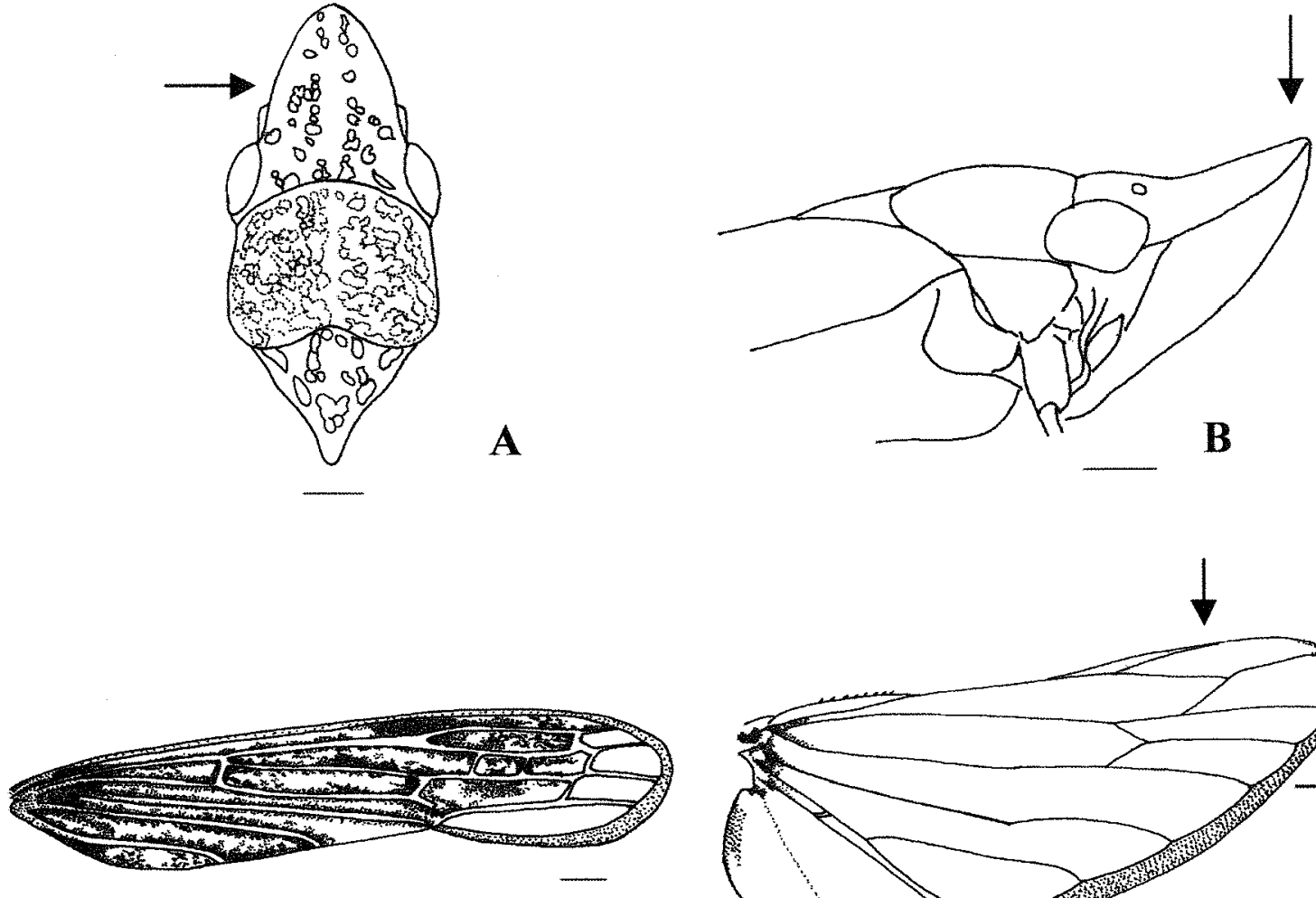

C
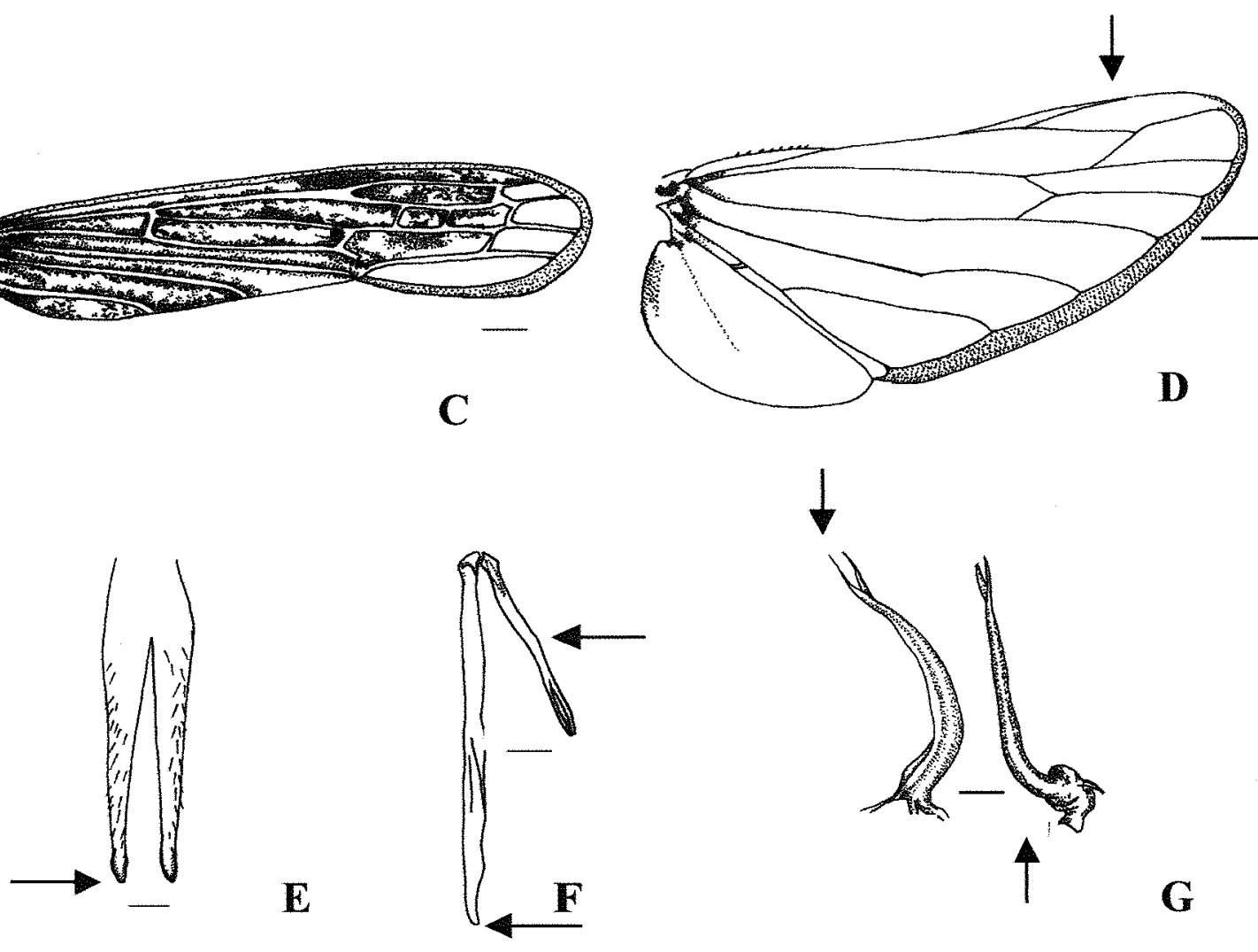

$\mathbf{E}$

G

Figura 10 - Acrogonia sp. (A e B) cabeça, pronoto e escutelo (vista dorsal e lateral); (C) asa anterior; (D) asa posterior; (E) placa subgenital; (F) estilo e conectivo (vista dorsal); (G) edeago (vista lateral); (escala $A, B, C$ e D: 0,5 mm; E e F: $0,25 . \mathrm{mm} ; \mathrm{G}: 0,1 \mathrm{~mm})$. 
os ápices estreitos e triangulares, estendendo-se além do ápice do pigóforo (Fig. 11F); estilo sem lobo apical, estendendo-se além do ápice do conectivo; conectivo em T (Fig. $11 \mathrm{G})$; edeago simétrico, muito pequeno, curvado dorsalmente na metade apical, haste estreita apicalmente em vista ventral, margem reta na base e convexo no comprimento (Fig. 11H e 11I); paráfises e processos ausentes.

Abdome do macho: Com um par de pequenos apódemas basiventrais (Fig. 11E).

Comprimento: Machos: 4,75 mm $\pm 0,16(4,5-5,0 \mathrm{~mm})$. Fêmeas: 5,13 mm $\pm 0,15(4,75-$ $5,25 \mathrm{~mm})$.

Diagnose: Espécie muito colorida, podendo apresentar ou não conspícuas manchas escuras na coroa. Edeago pequeno, simétrico, curvado dorsalmente na metade apical.

Nota Taxonômica: O gênero Bucephalogonia é monofilético. Não está relacionado com nenhuma outra espécie em razão das estruturas genitais de macho e fềmea (Young, 1977).

Distribuição Geográfica: Argentina (Jujuy, Córdoba, Santa Fé, Misiones), Brasil (MG, BA, MT, SP) e Bolívia (Young, 1977; Zanol \& Menezes, 1982; Cavichioli \& Zanol, 1991; Coll, 1996).

Hospedeiros: Citros (Citrus sinensis L. Osbeck), vegetação espontânea do pomar, capim-de-burro (Cynodon dactylon (L.) Pers. cv. Licia), estilosantes (Stylosanthes guyanensis Sw. cv. Schofield), pangola (Digitaria decumbes Stent cv. Transvala e Digitaria decumbens Stent), algodoeiro (Gossypum hirsutum L.), batatinha (Solanun tuberosum L.), grama (Young, 1977; Zanol \& Menezes, 1982; Coll, 1996).

Material: BRASIL. São Paulo: Bebedouro, 15/VIII/1997 (T. A. Giustolin), 2 fềmeas (ESALQ); 10/X/1997 (T. A. Giustolin), 1 macho (ESALQ); 29/VIII/1997 (T. A. Giustolin), 1 macho e 1 fềmea (ESALQ); 30/X/1997 (T. A. Giustolin), 1 macho (ESALQ); 15/VIII/1998 (T. A. Giustolin), 1 macho e 1 fềmea (ESALQ); 11/VII/1998 (R. Krügner), 10 fềmeas (ESALQ); Colina, 29/VIII/1997 (T. A. Giustolin), 1 macho (ESALQ); Colina, 15/VIII/1997 (T. A. Giustolin), 5 machos e 3 fềmeas (ESALQ); Turvinia, 25/IX/1997 (T. A. Giustolin), 1 fềmea (ESALQ); Monte Azul Paulista, 01/V/1998 (R. Krügner), 2 machos (ESALQ); Mato Grosso: Anastácio, 13/VIII/1998 (C. M. Oliveira), 1 macho (ESALQ). 
Comentários: Coloração de modo geral amarela com a área opaca da asa e algumas áreas do pronoto esverdeadas. A perda de cor é uma característica pronunciada dessa espécie e observada em todas as espécies estudadas por Osborn (1926). É encontrada em plantas novas ou em replantas dentro do talhão. Pode ser também capturada na vegetação invasora do pomar em proporções semelhantes às da planta cítrica. Tem sido muito mais problema em viveiros que as outras espécies vetoras (Paiva et al., 1996). É uma espécie constante em pomares cítricos e cerrado. É coletada em praticamente todas as avaliações, nos diferentes hábitats.

\section{Dilobopterus costalimai Young, 1977}

Cabeça: Coloração variando de amarela a alaranjada; coroa com as margens pretas na área correspondente as impressões musculares, linha mediana preta expandida apicalmente ligando cada lado das margens e com uma pequena mancha preta levemente curvada, estendendo-se posteriormente de cada ocelo para a margem posterior da coroa (Fig. $12 \mathrm{~A}$ ); face convexa e amarela com uma pequena mancha mediana preta na base do clípeo.

Tórax: Coloração do pronoto variando de amarela a alaranjada com sinuosas faixas laterais pretas; margem anterior do pronoto estreita e faixas na forma de $\mathrm{W}$ no disco pronotal (Fig. 12 A ); grande mancha mediana preta na forma de Y no escutelo, com uma pequena mancha estreita saindo de cada lado do braço do Y para a margem lateral adjacente; asas anteriores com uma ampla área membranosa distal e somente as nervuras do clavo indistintas, com a margem costal alargada, ocasionalmente com manchas foscas no ápice e nas células anteapicais (Fig. 12B); asas posteriores com um conspícuo lobo jugal alargado, parcialmente separado do resto da asa e estendendo-se além do ápice do clavo das asas anteriores, quando em posição de repouso (Fig. 12C); comprimento do basitarso muito maior que a soma do comprimento dos distais; fórmula setal do fềmur posterior 2.1.1.0. 


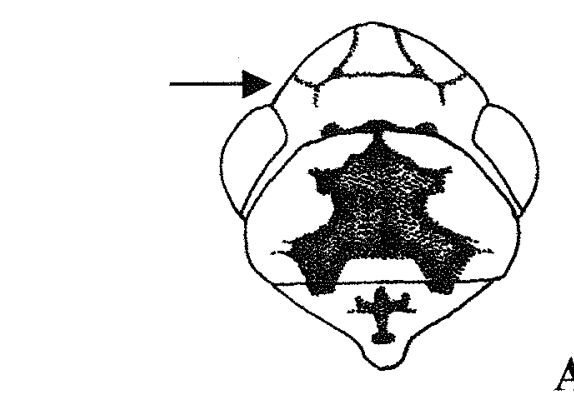

$\mathbf{A}$
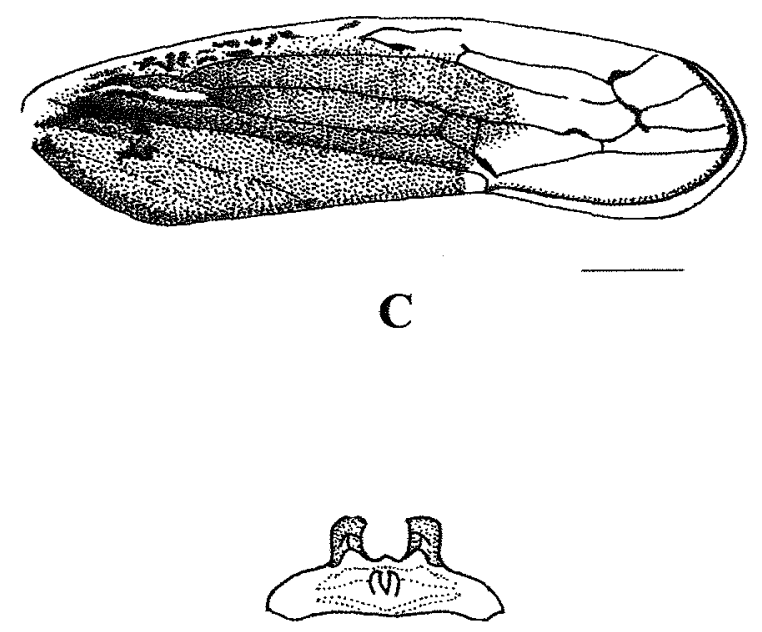

$\mathbf{E}$

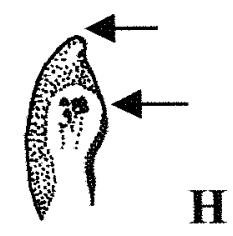

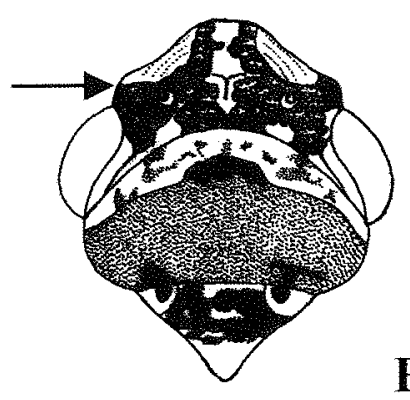
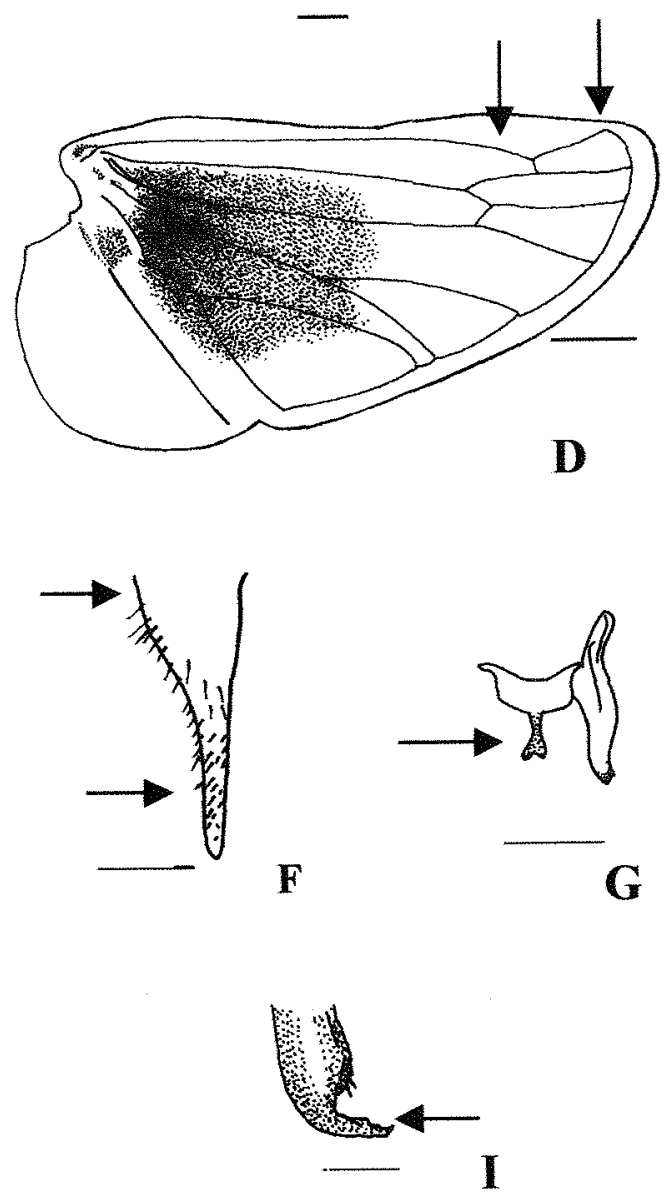

Figura 11 - Bucephalogonia xanthophis (A e B) cabeça, pronoto e escutelo (vista dorsal); (C) asa anterior; (D) asa posterior; (E) apódemas abdominais basais do macho; (F) placa subgenital (vista ventral); (G) conectivo e estilo (vista dorsal); $(\mathrm{H})$ edeago (vista ventral); (I) edeago (vista lateral) (escala A, C, D e E: $0,5 \mathrm{~mm}$; B, F e G: 0,25 mm; H e I: 0,1 mm). 
Genitália do macho: Pigóforo com numerosas macrocerdas irregularmente dispersas, com dois pequenos processos apicais em vista dorsal (Fig. 12D); placas subgenitais pequenas, triangulares, gradualmente estreitando-se através do seu comprimento, com o ápice arredondado e macrocerdas multiseriadas em quase toda a sua extensão (Fig. 12E); estilo estendendo-se além do ápice do conectivo, com um distinto lobo pré-apical; conectivo pequeno, na forma de $\mathrm{Y}$, com os braços amplamente divergentes (Fig. 12F); edeago com um pequeno lobo estendendo-se posteriormente, redondo apicalmente (Fig. $12 \mathrm{G}$ ); paráfise assimétrica consistindo de um fino ramo que se alarga próximo a base, podendo apresentar o ápice denteado (Fig. 12H).

Comprimento: Machos: $8,15 \mathrm{~mm} \pm 0,34(7,5-8,5 \mathrm{~mm})$. Fêmeas: $8,95 \mathrm{~mm} \pm 0,16(8,5-9,0$ $\mathrm{mm})$.

Diagnose: Espécie de coloração amarela ou alaranjada com uma série de manchas pretas formando desenhos característicos na cabeça, pronoto e escutelo; asas posteriores com o lobo jugal alargado; presença de paráfises assimétricas.

Nota Taxonômica: Este é o único gênero cuja asa em posição de repouso apresenta a área anal distinta do resto da asa (Evans, 1947). D. costalimai é uma espécie relacionada com $D$. dispar (Germar) da qual difere pelas manchas pretas no dorso anterior e pelo edeago com uma nítida separação entre o lobo e a haste (Young, 1977).

Distribuição Geográfica: Brasil (MT, MG e SP), Paraguai (Asunción) e Argentina (Bella Vista, Corrientes e Misiones) (Young, 1977; Zanol \& Menezes, 1982; Coll, 1996).

Hospedeiros: Citros (Citrus sinensis L. Osbeck) e vegetação espontânea do pomar (Young, 1977; Coll, 1996).

Material: BRASIL. São Paulo: Bebedouro, 04/VII/1997 (R. Krügner), 2 machos e 2 fềmeas (ESALQ); 09/VII/1997 (R. Krügner), 2 machos e 2 fềmeas (ESALQ); IV/1998 (S. Roberto), 2 machos (ESALQ); 15/V/1998 (T. A. Giustolin), 7 machos e 1 fềmea (ESALQ); Turvínia, 22/XII/1997 (T. A. Giustolin), 1 macho (ESALQ).

Comentários: Os ovos são colocados nas folhas tenras e novas. São depositados isoladamente, sob a epiderme da folha e ao longo das nervuras, principalmente a central (Paiva et al., 1996). A eclosão das ninfas dá-se pela extremidade do ovo, onde deixa um pequeno orificio. Passa por cinco ínstares antes de atingir a fase adulta, com duração 
média de 65 dias à temperatura flutuante (Almeida \& Lopes, 1997). Esta é uma espécie que na região de Bebedouro é constante em pomares cítricos, embora também ocorra em menores proporções, nos outros hábitats.

\section{Ferrariana trivittata (Signoret, 1854)}

Cabeça: Moderadamente produzida, com margem anterior arredondada em vista dorsal (Fig. 13A); ocelo localizado a uma pequena distância da linha imaginária entre os ângulos oculares anteriores, numa área com concavidade rasa, cada um situado mais próximo do olho que da linha mediana da coroa; coroa com uma faixa laranja ou vermelha na margem anterior, levemente curvada, em cada lado do ápice, deixando uma pequena área marginal ântero-lateral, não coberta pela faixa; ausência de pubescência; sutura lateral do clípeo estendendo-se sobre a coroa e atingindo os ocelos; lóbulos suprantenais não protuberantes em vista dorsal; impressões musculares distintas; clípeo convexo e medianamente achatado.

Tórax: Largura do pronoto coincidindo com a largura transocular da cabeça; margem anterior do disco do pronoto com uma faixa de cor laranja; ausência de pubescência; asas anteriores coloridas com faixas longitudinais de cores contrastantes (laranja ou vermelho e azul) e uma porção membranosa incluindo todas as células apicais, venação indistinta ou obscura no restante da superfície da asa, com leves pontuações e ultrapassando o ápice do ovipositor da fềmea em posição de repouso (Fig. 13B); fórmula setal dos fêmures posteriores 2.1.1; comprimento do basitarso da perna posterior maior que a soma do comprimento dos distais, com duas fileiras paralelas de cerdas na superfície plantar.

Genitália do macho: Pigóforo produzido posteriormente, afilado no ápice; com macrocerdas na metade apical; placas subgenitais finas no ápice, não se estendendo além do ápice do pigóforo, com macrocerdas unisseriadas (Fig. 13C ); estilo truncado no ápice e não se estendendo além do ápice do conectivo; conectivo em $\mathrm{Y}$, com a haste muito maior que os braços (Fig. 13E); edeago com haste reta (Fig. 13F) e apódemas 


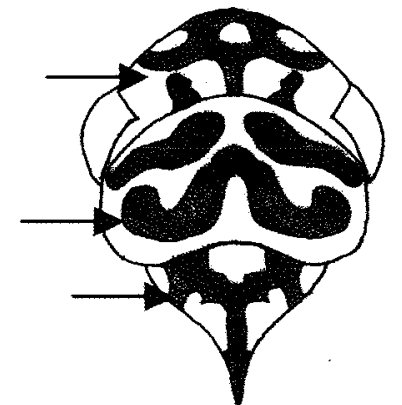

A

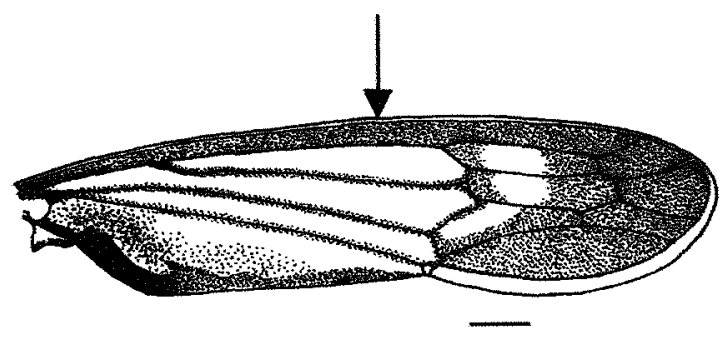

B
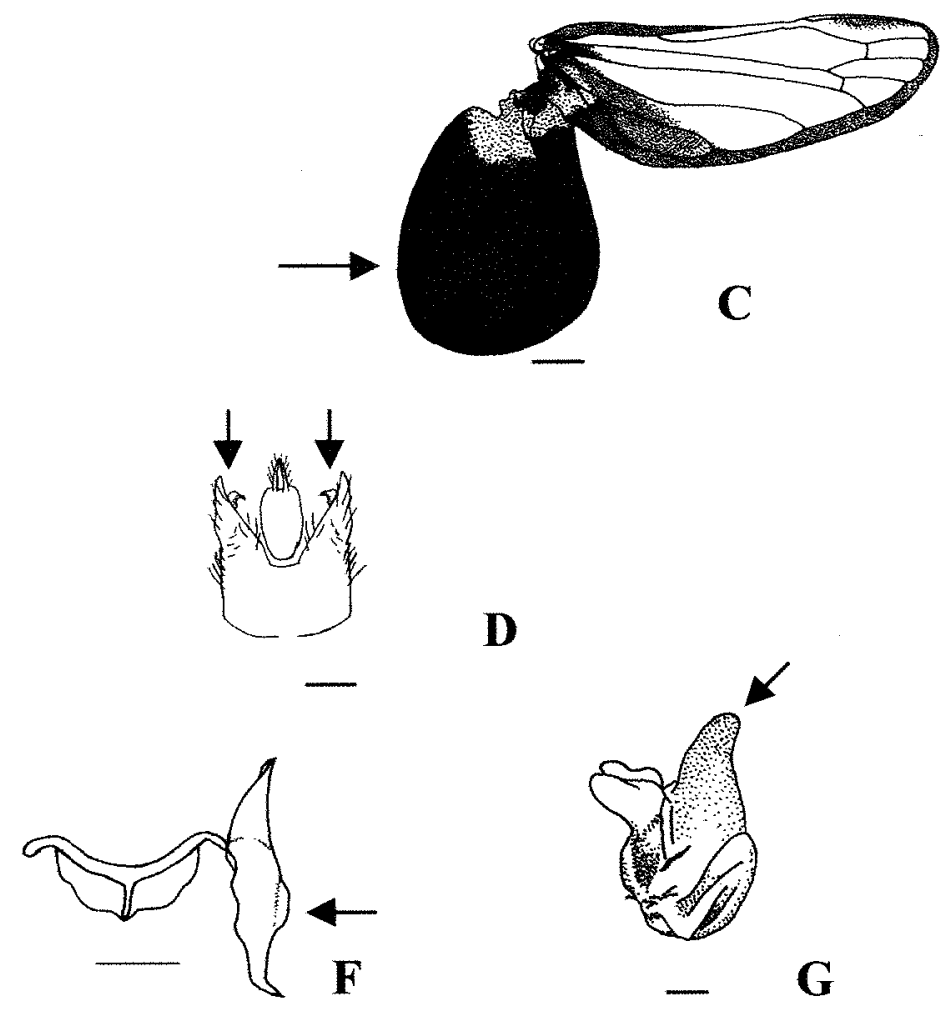

D
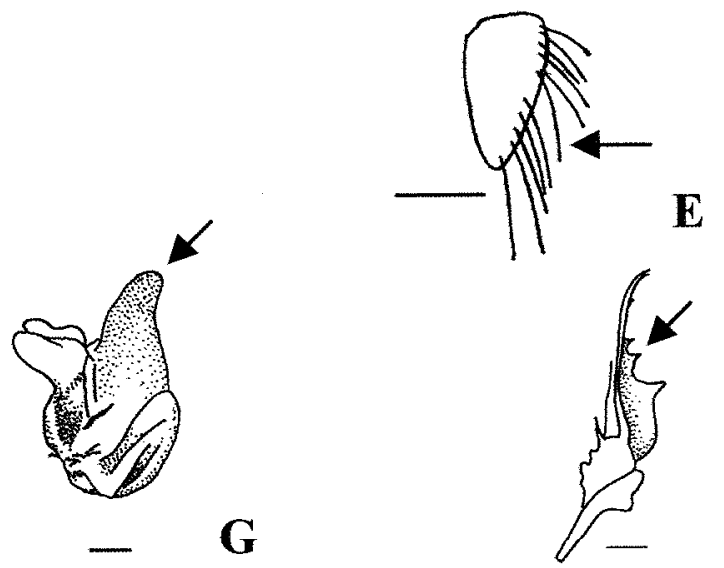

$\mathbf{H}$

Figura 12 - Dilobopterus costaliamai (A) cabeça, pronoto e escutelo (vista dorsal); (B) asa anterior; (C) asa posterior com o lobo jugal alargado; (D) pigóforo (vista dorsal); (E) placa subgenital (vista ventral); (F) conectivo e estilo (vista dorsal); G) edeago (vista lateral); $(\mathrm{H})$ paráfise (vista dorsal) (escala $\mathrm{A}, \mathrm{B}, \mathrm{C}$, D e E: $0,5 \mathrm{~mm}$; F: $0,2 \mathrm{~mm}$; G e H: $0,16 \mathrm{~mm}$ ). 
basais tão longos quanto a haste, estendendo-se posteriormente; ausência de processos; paráfises dispostas em dois ramos simétricos (Fig. 13D).

Comprimento: Machos: 7,57 mm $\pm 0,45(6,8-8,0 \mathrm{~mm})$. Fêmeas: $8,16 \mathrm{~mm} \pm 0,18(8,0-8,6$ $\mathrm{mm})$.

Diagnose: Asas anteriores coloridas com faixas longitudinais de cores contrastantes (laranja ou vermelho e azul); faixa de cor laranja ou vermelha na coroa, não ocupando completamente a margem anterior da cabeça; edeago pequeno com a haste do mesmo comprimento que os apódemas basais.

Nota Taxonômica: Essa espécie separa-se de T. submarginalis, outra espécie que também ocorre no Brasil, por apresentar a haste do edeago reta e uma faixa laranja ou vermelha na margem anterior da coroa, que não é completamente marginal (Young, 1977).

Distribuição Geográfica: Brasil (MG e SP), Costa Rica, Paraguai, Bolívia, Argentina, Colômbia, Peru, Panamá. (Young, 1977; Zanol \& Menezes, 1982; Cavichioli \& Zanol, 1991; Coll, 1996; Coelho, 1997).

Hospedeiros: Raramente encontrada sobre a planta cítrica, ocorre principalmente na vegetação espontânea do pomar (predominantemente gramíneas) (Gravena et al., 1997). Material: BRASIL. São Paulo: Bebedouro, 11/IV/ 1997 (T. A. Giustolin), 5 machos e 2 fềmeas (ESALQ); 09/V/ 1997 (T. A. Giustolin), 2 machos e 3 fềmeas (ESALQ); 24/IV/ 1997 (T. A. Giustolin), 2 fềmeas (ESALQ); Turvínia, 23/IV/ 1997 (T. A. Giustolin), 1 macho e 1 fềmea (ESALQ); 18/VI/ 1997 (T. A. Giustolin), 1 macho e 4 fềmeas (ESALQ); 3/VII/ 1997 (T. A. Giustolin), 1 macho (ESALQ); 23/IV/ 1997 (T. A. Giustolin), 1 macho e 1 fềmea (ESALQ); 08/V/1997 (T. A. Giustolin) 3 machos e 2 fêmeas (ESALQ).

Comentários: Espécie muito colorida e vistosa. A presença de uma faixa vermelha ou alaranjada na coroa é um caráter distintivo em relação aos outros gêneros de Cicadellini (Young, 1977). É atraída pela luz (Gravena et al., 1997). É uma espécie coletada predominantemente na vegetação espontânea do pomar através de succionador motorizado. 


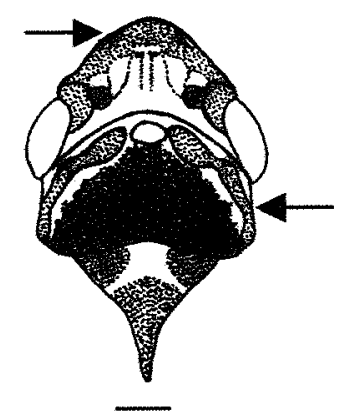

A
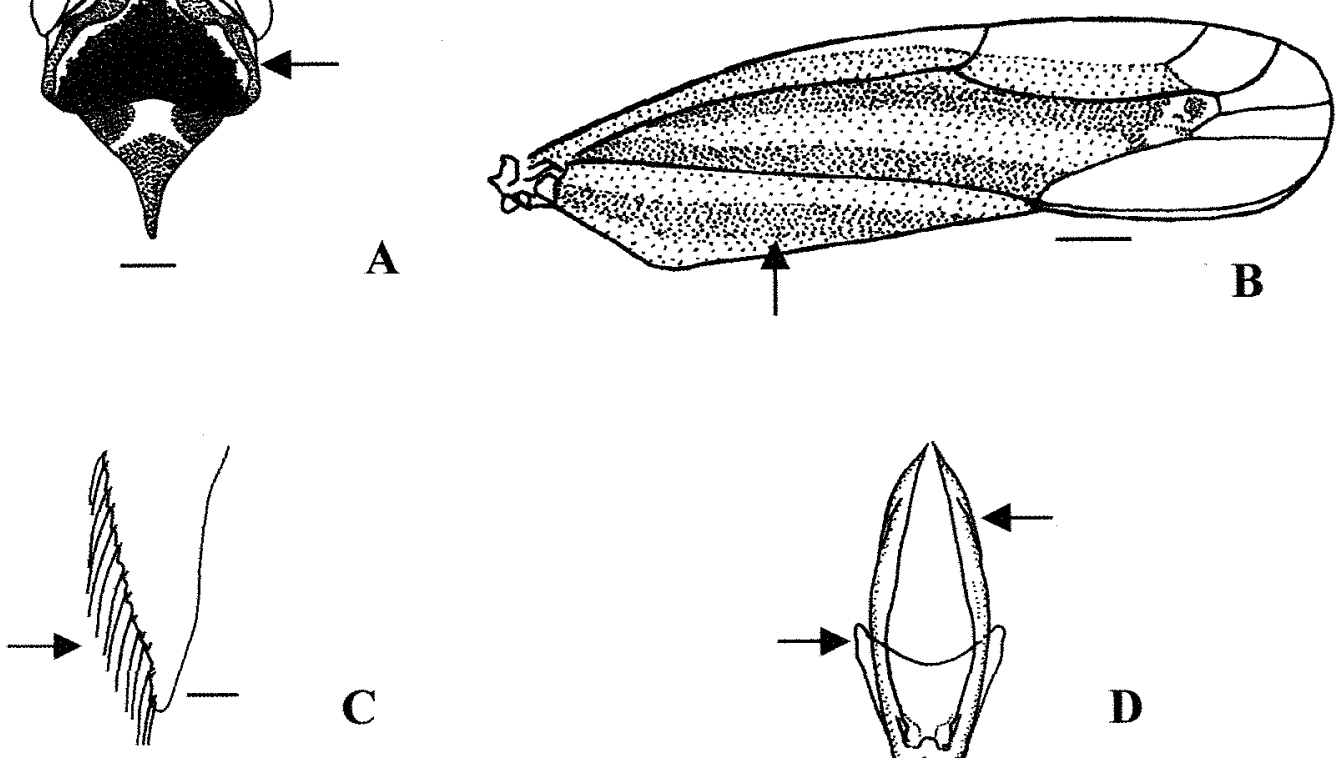

C
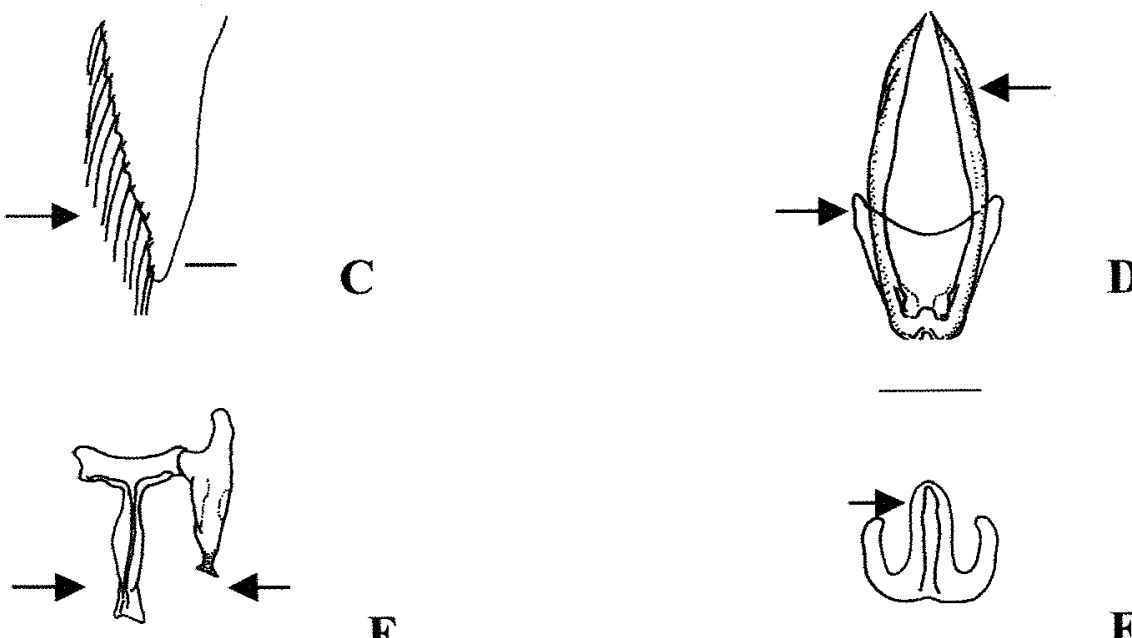

$\mathbf{E}$

F

Figura 13 - Ferrariana trivittata (A) cabeça, pronoto e escutelo (vista dorsal); (B) asa anterior; (C) placa subgenital (vista ventral); (D) paráfises e apódemas basais (vista ventral); (E) conectivo e estilo (vista dorsal); (F) edeago (vista ventral) (escala A: 0,4 mm; B: 0,5 mm; C: 0,125 mm; D: 0,2 mm; E e F: 0,25 mm). 


\section{Hortensia similis (Walker, 1851)}

Cabeça: Com margem anterior arredondada em vista dorsal (Fig. 14A); ocelo localizado quase na linha imaginária entre os ângulos oculares anteriores, cada um localizado mais próximo ao olho do que da linha mediana da coroa; coroa convexa, com um padrão de manchas lineares escuras próximas aos ocelos; sutura lateral do clípeo estendendo-se sobre a coroa e atingindo os ocelos; lóbulos suprantenais não protuberantes em vista dorsal; impressões musculares distintas.

Tórax: Largura do pronoto menor ou igual a largura transocular da cabeça; disco do pronoto levemente rugoso transversalmente (estrias na porção posterior) e a porção anterior com manchas lineares pretas; ausência de pubescência; asas anteriores com uma área opaca esverdeada delimitada por uma membrana incluindo todas as células apicais, venação indistinta ou obscura, com pontuações e ultrapassando o ápice do ovipositor da fêmea em posição de repouso; fómula setal 2.1.1; comprimento do basitarso da perna posterior maior que a soma do comprimento dos distais, com duas fileiras paralelas de cerdas na superfície plantar.

Genitália do macho: Pigóforo fortemente produzido, estreitando-se do ápice para a margem dorsoapical; com poucas macrocerdas no ápice; placas subgenitais triangulares, estreitas ou pontiagudas no ápice, estendendo-se além do ápice do pigóforo, margem com macrocerdas unisseriadas (Fig. 14B), estilo truncado no ápice e estendendo-se além do ápice do conectivo; conectivo na forma de $\mathrm{Y}$, com os braços amplamente divergentes (Fig. 14C); edeago simples, pequeno, em vista lateral com a haste não abruptamente alargada no ápice (Fig. 14D e 14E); paráfises e processos ausentes.

Comprimento: Machos: 6,2 $\mathrm{mm} \pm 0,35(6,0-7,0 \mathrm{~mm})$ Fêmeas: 6,77 $\mathrm{mm} \pm 0,51$ (5,5-7,0 $\mathrm{mm})$.

Diagnose: Cabeça, margem anterior do pronoto e escutelo verde-claros; coroa com uma série de manchas lineares pretas próximas aos ocelos; haste do edeago não abruptamente alargada no ápice. 
Nota Taxonômica: Cicadella cuneatula Osborn foi considerada sinonímia de $H$. similis com base no estudo da série-tipo; Tettigonia prolixa Lethierry foi sinonimizada com base no exame do lectótipo (Young, 1977).

Distribuição Geográfica: Extremamente abundante, ocorre na América tropical e subtropical ( Osborn, 1926). Tem sido encontrada no sul dos EUA e em numerosas localidades do México, América Central, e nos países da América do Sul, exceto Uruguai e Chile (Young, 1977). No Brasil foi encontrada em sete estados (MT, BA, RJ, SP, RR, RS, MG) (Zanol \& Menezes, 1982; Cavichioli \& Zanol, 1991; Coll, 1996; Coelho, 1997).

Hospedeiros: Citros (Citrus sinensis L. Osbeck e Citrus sp.), vegetação espontânea do pomar, milho (Zea Mays L.), sorgo (Sorghum vulgare L, cana (Saccharum officinarum L.), Dolichos sp., feijão (Phaseolus vulgaris L.), morango (Fragaria sp.), Crotalaria, Bidens sp., alfafa (Medicago sativa L.), Paspalum sp., Pennisetum sp., Panicum barbinode, capim-buffel (Cenchrus ciliares L. cv. Biloela), capim-estrela (Cynodon plectostachyum Pielger), capim-colonião (Panicum maximum Jacq. cv. Gaton Panic e $P$. maximum Jacq. cv. Green Panic), pangola (Digitaria swazilandensis Stent, Digitaria setivalva Stent, Digitaria decumbens Stent), soja-perene (Glycine wightii (Wir. Grah ex Wight \& And. Arn.) Verd. Court.), capim-sete-léguas (Brachiaria sp.), capim-quicuio (Pennisetum cladestinum Hochst), braquiária (Brachiaria decumbens Stapf.), gramaseda (Cynodon dactylon (L.) Pers. cv. Licia) (Young, 1977; Zanol \& Menezes, 1982; Coll, 1996).

Material: BRASIL. São Paulo: Bebedouro, 11/IV/1997 (T. A. Giustolin), 3 machos e 2 fềmeas (ESALQ); 18/VII/1997 (T. A. Giustolin), 5 fềmeas (ESALQ); 15/VIII/1997 (T. A. Giustolin), 3 fêmeas (ESALQ); 18/VII/1997 (T. A. Giustolin), 1 macho (ESALQ); 16/III/1998 (R. Krügner), 1 macho e 2 fềmeas (ESALQ), Turvínia, 26/IX/1997 (T. A. Giustolin), 2 machos e 1 fềmea (ESALQ); 28/VIII/1997 (T. A. Giustolin), 1 macho e 5 fềmeas (ESALQ); 18/VI/1997 (T. A. Giustolin); 2 machos e 3 fềmeas (ESALQ).

Comentários: Não têm sido observadas diferenças estruturais, que dão sustentação a variação de cor. É a mais comum espécie de Cicadellini no Novo Mundo e uma das mais difundidas. Pode haver uma variação-intra específica na forma do edeago. $O$ gênero 
Hortensia é similar em muitos aspectos ao Kapateira, principalmente as fềmeas, mas difere pelo porte menor, pelo pigóforo do macho mais fortemente produzido, com o conectivo em $\mathrm{Y}$ e o edeago muito menor quando comparado ao longo edeago de Kapateira (Young, 1977). Espécie extremamente abundante que se alimenta primariamente de gramíneas, registrada como transmissora de fitovirose em arroz (Wilson \& Claridge, 1991). Foi uma das espécies mais abundantes durante a estação chuvosa na Mata Atlântica (Viçosa-MG) (Coelho, 1997). Na região de Bebedouro essa espécie é coletada nos pomares cítricos, na cana-de-açúcar e no brejo.

\section{Macugonalia cavifrons (Stål, 1862)}

Cabeça: Levemente produzida com margem anterior alargada em vista dorsal (Fig. 15A); ocelo localizado na linha ou levemente atrás da linha imaginária entre os ângulos oculares anteriores, cada um situado mais próximo do olho que da linha mediana da coroa; sutura lateral do clípeo estendendo-se sobre a coroa e atingindo os ocelos; lóbulos suprantenais não-protuberantes em vista dorsal; impressões musculares não muito distintas; clípeo convexo e medianamente achatado; face com manchas escuras, principalmente no clípeo, restando somente uma área mediana amarelada sem manchas; coroa com o mesmo padrão de manchas das asas anteriores.

Tórax: Largura do pronoto menor que a largura transocular da cabeça; pronoto com o mesmo padrão de manchas das asas anteriores; essas com a extremidade membranosa, nervuras indistintas ou obscuras e ultrapassando o ápice do ovipositor da fềmea, quando em repouso (Fig. 15B); fórmula setal do fêmur posterior 2.1.1; comprimento do basitarso da perna posterior maior que a soma do comprimento dos distais, com duas fileiras paralelas de cerdas na superfície plantar. 

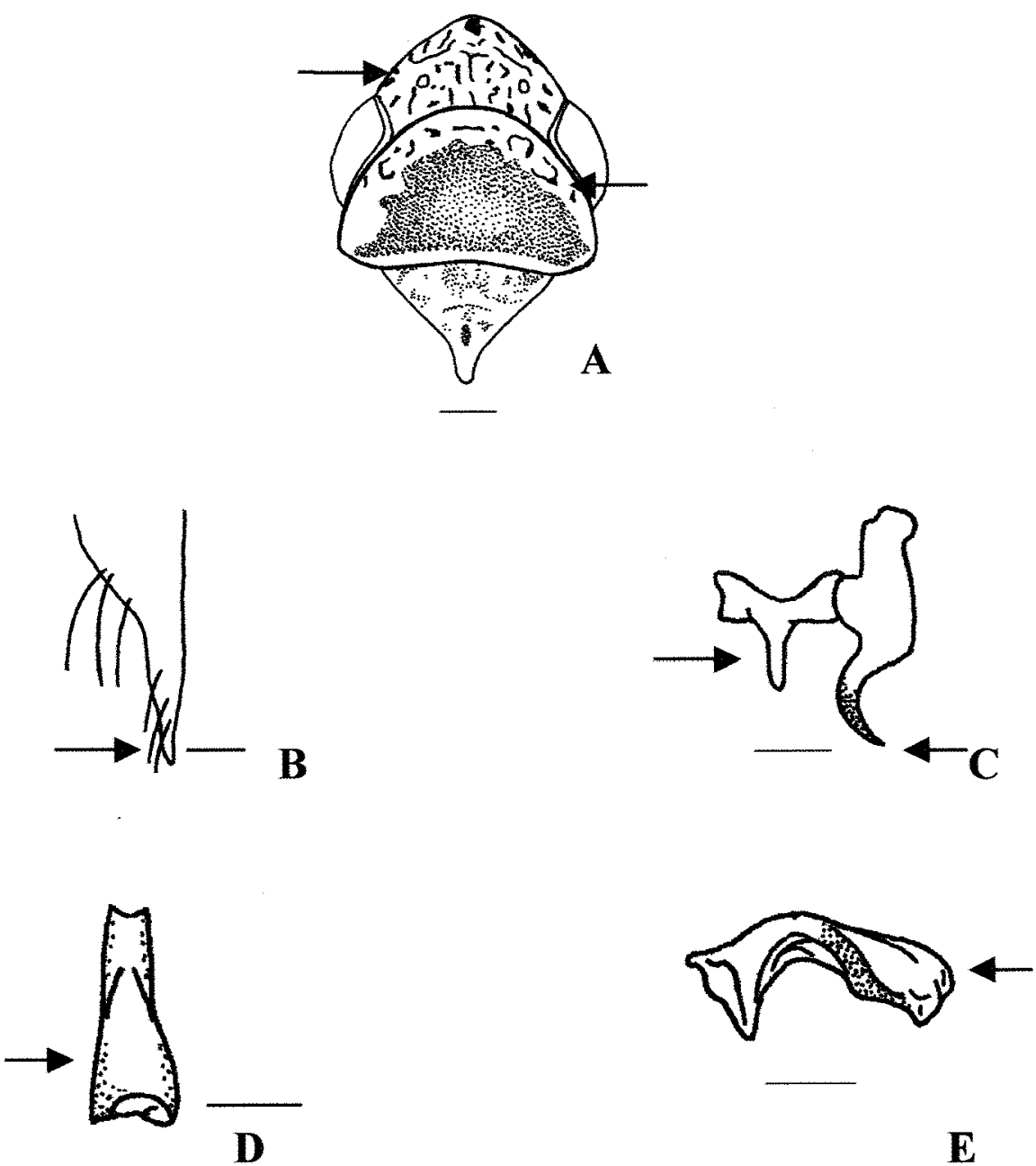

Figura 14 - Hortensia similis (A) cabeça, pronoto e escutelo (vista dorsal); (B) placa subgenital (vista dorsal); (C) conectivo e estilo (vista dorsal); (D) edeago (vista ventral); (E) edeago (vista lateral) (escala A: 0,25 mm; B e C: 0,125 $\mathrm{mm}$; D e E: $0,1 \mathrm{~mm}$ ). 
Genitália do macho: Pigóforo produzido posteriormente, afilado no ápice; com macrocerdas localizadas mais próximas do ápice; placas subgenitais pequenas, triangulares não se estendendo além do ápice do pigóforo; estilo estendendo-se além do ápice do conectivo e com um lobo lateral próximo a metade do comprimento; conectivo em Y com os braços amplamente divergentes (Fig. 15C); edeago convexo em vista dorsal, com um par de finos processos iniciando-se na base (vista ventral) e estendendose posteriormente ao ápice do edeago (Fig. 15D); paráfises ausentes.

Comprimento: Machos: 7,8 mm $\pm 0,35$ (7,1-8,1 mm). Fêmeas: 8,21 mm $\pm 0,35(7,9-9,0$ $\mathrm{mm})$.

Diagnose: Coroa com o mesmo padrão de manchas das asas anteriores; face com muitas manchas escuras no disco do clípeo, e somente uma área amarelada central não manchada.

Nota Taxonômica: A interpretação de Tettigonia cavifrons Stål feita por Young (1977) foi baseada em espécimens comparadas com o lectótipo. $M$. cavifrons está relacionada à M. sobrina (Stål) e à M. testudinaria (Fowler), no entanto sobrina é menor e as manchas pretas no clípeo estendem-se sobre a sutura lateral deste e testudinaria apresenta a face com o disco do clípeo amarelo e com poucas manchas lineares escuras.

Distribuição Geográfica: Brasil, Paraguai, Bolívia, Argentina, Colômbia, Peru, Venezuela (Young, 1977; Zanol \& Menezes, 1982; Coll, 1996).

Hospedeiros: Citrus sinensis (L.) e vegetação espontânea do pomar (Coll, 1996).

Material: BRASIL. São Paulo, Bebedouro, 01/VIII/1997 (T. A. Giustolin), 3 machos (ESALQ); Bebedouro, 29/VIII/1997 (T. A. Giustolin), 2 machos (ESALQ); 12/IX/1997 (T. A. Giustolin), 2 machos (ESALQ); 18/VII/1997 (T. A. Giustolin), 3 machos (ESALQ); 10/X/1997 (T. A. Giustolin), 3 machos (ESALQ); 04/VII/1997 (T. A. Giustolin), 1 macho (ESALQ); 30/X/1997 (T. A. Giustolin), 1 macho (ESALQ); 26/XI/1997 (T. A. Giustolin), 2 fềmeas (ESALQ); 10/X/1997 (T. A. Giustolin), 1 fềmea (ESALQ); 19/VI/1997 (T. A. Giustolin), 1 fềmea (ESALQ); Colina, 03/VII/1997 (T. A. Giustolin), 1 macho e 1fềmea (ESALQ); 03/VII/1997 (Giustolin, T. A.), 1 macho e 1 fềmea (ESALQ); Piracicaba, 26/VIII/1997 (R. Krügner), 4 fềmeas (ESALQ); Turvínia, , 14/VIII/1997 (T. A. Giustolin), 2 fềmeas (ESALQ); 11/IX/1997 (T. A. Giustolin), 3 
machos (ESALQ); 25/IX/1997 (T. A. Giustolin), 2 machos (ESALQ); 28/VIII/1997 (T. A. Giustolin), 2 machos (ESALQ); 31/VII/1997 (T. A. Giustolin), 1 fềmea (ESALQ); 03/VII/1997 (T. A. Giustolin), 1 fềmea (ESALQ); 04/VI/1997 (T. A. Giustolin), 1 fềmea (ESALQ).

Comentários: De modo geral, as espécies pertencentes ao gênero Macugonalia são identificadas por caracteres externos, já que a genitália do macho é muito pouco variável e a da fềmea é bastante similar na maioria das espécies. Essa espécie é muito variável no tamanho, com manchas e pontuações leves em uma pequena área da coroa, pronoto, escutelo e clípeo (Young, 1977). É uma espécie constante na área de floresta hidrofólia e de cerrado próximo ao pomar, mas ocorre também no pomar de citros, cana-de-açúcar, café e floresta semi-decidual aluvial, em menor proporção.

\section{Macugonalia leucomelas (Walker, 1851)}

Cabeça: Levemente produzida com margem anterior alargada em vista dorsal; de coloração preta mosqueada de branco (Fig. 15E ); ocelo localizado levemente atrás da linha imaginária entre os ângulos oculares anteriores, cada um situado mais próximo do olho do que da linha mediana da coroa; sutura lateral do clípeo estendendo-se sobre a coroa e atingindo os ocelos; coroa com uma faixa transversal, geralmente interrompida sobre a base; lóbulos suprantenais não-protuberantes em vista dorsal; impressões musculares não muito distintas.

Tórax: Largura do pronoto menor do que a largura transocular da cabeça; pronoto com bordas pálidas nas margens lateral e posterior e variavelmente manchado; porção anterior do pronoto e escutelo de coloração escura com manchas amarelas; porção posterior do pronoto e asas anteriores seguindo o mesmo padrão de coloração e de manchas; asas anteriores com duas manchas largas distintas, de cor clara, uma logo atrás do escutelo, a outra atravessando o ápice do clavo, com nervuras indistintas ou obscuras e ultrapassando o ápice do ovipositor da fêmea com as asas em posição de repouso (Fig. 15F); fórmula setal do fềmur posterior 2.1.1; comprimento do basitarso da perna 
posterior maior que a soma do comprimento dos distais, com duas fileiras paralelas de cerdas na superfície plantar.

Genitália do macho: Pigóforo produzido posteriormente, alargado no ápice, com grupos de macrocerdas localizadas no ápice posterior e estendendo-se sobre as margens ventrais; placas subgenitais pequenas, triangulares, não se estendendo além do ápice do pigóforo; estilo estendendo-se além do ápice do conectivo; conectivo em Y com os braços amplamente divergentes (Fig. 15G); edeago pequeno, convexo em vista dorsal, com um par de finos e longos processos iniciando-se na base (vista ventral) e estendendo-se posteriormente ao ápice do edeago (Fig. 15H ); paráfises ausentes.

Comprimento: Machos: 5,29 mm $\pm 0,26(4,7-5,65 \mathrm{~mm})$. Fêmeas: 5,82 $\mathrm{mm} \pm 0,16(5,6-$ $6,1 \mathrm{~mm})$.

Diagnose: Asas anteriores escuras com duas manchas largas de cor marfim. Coloração geral preta com algumas pequenas manchas de cor clara.

Nota Taxonômica: A interpretação de Tettigonia leucomelas Walker feita por Young (1977) foi baseada no macho, comparado com o holótipo do Museu Britânico Young colocou albopunctula (Taschenberg) em sinonímia com leucomelas, como resultado do estudo de somente um espécimen da coleção de Taschenberg da Martin Luther University. A genitália de Tettigonia rubricosa é similar a de $M$. leucomelas, mas a paráfise vestigial é levemente diferente e a coroa e o pronoto não são marcados de amarelo-alaranjado (Young, 1977).

Distribuição Geográfica: Brasil (BA, SP), Paraguai, Bolívia, Argentina (Misiones) (Young, 1977; Zanol \& Menezes, 1982; Coll, 1996).

Hospedeiros: Citrus sinensis (L.), vegetação espontânea do pomar, estilosantes (Stylosanthes guyanensis Sw. cv. Cook), algodoeiro (Gossypium hirsutum L.), guanxuma (Sida rhombifolia L.), alface (Lactuca sativa L.) (Zanol \& Menezes, 1982; Coll, 1996).

Material: BRASIL. São Paulo: Bebedouro, 18/VII/1997 (T. A. Giustolin), 13 machos e 9 fềmeas (ESALQ); Monte Azul Paulista, 01/V/1998 (R. Krügner), 2 machos e 1 fềmea (ESALQ). 
Comentário: É a espécie mais comum encontrada em coleções (Young, 1977). Signoret (1853) verificou que essa espécie é extremamente variável, as manchas claras nas asas anteriores podem ser menores, as nervuras mosqueadas de amarelo e as asas em algumas espécies podem ser mais escuras do que em outras, face quase sempre preta. Na região de Bebedouro, esta espécie é coletada principalmente em pomar, floresta semi-decidual aluvial e brejo.

\section{Oncometopia facialis (Signoret, 1854)}

Cabeça: Mais larga que longa; margem anterior arredondada; coloração marrom avermelhada levemente violeta com uma série de manchas pretas nas porções dorsal e ventral; superfície bastante dilatada após a mancha triangular preta da fronte (Fig. 16A); com granulações na região central, de cada lado do clípeo, entre as impressões musculares; clípeo dilatado, convexo, não achatado medianamente, nem côncavo, com a porção mediana mais ou menos larga e escura; ocelos localizados antes da linha imaginária que tangencia os ângulos oculares anteriores, mais próximos aos olhos compostos do que entre si e equidistantes da linha mediana da coroa, lóbulos suprantenais salientes, em vista dorsal; olhos ovalados e salientes.

Tórax: Marron avermelhado levemente violeta; largura do pronoto menor que a largura transocular da cabeça, margem anterior irregularmente escura; disco do pronoto pontuado, rugoso e pubescente; proepímero mais largo que longo; escutelo com uma mancha triangular escura na margem posterior; asas anteriores opacas, com nervação distinta, porém com uma área membranosa no ápice (incluindo células apicais e parcialmente células anteapicais) (Fig. 16B); asas posteriores com a nervura $R_{2+3}$ incompleta e duas nervuras cubitais distintas (Fig. 16C); comprimento do basitarso da perna posterior maior que a soma do comprimento dos distais. 
A

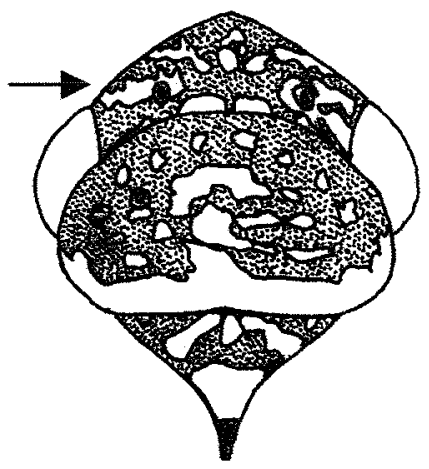

$\mathbf{E}$
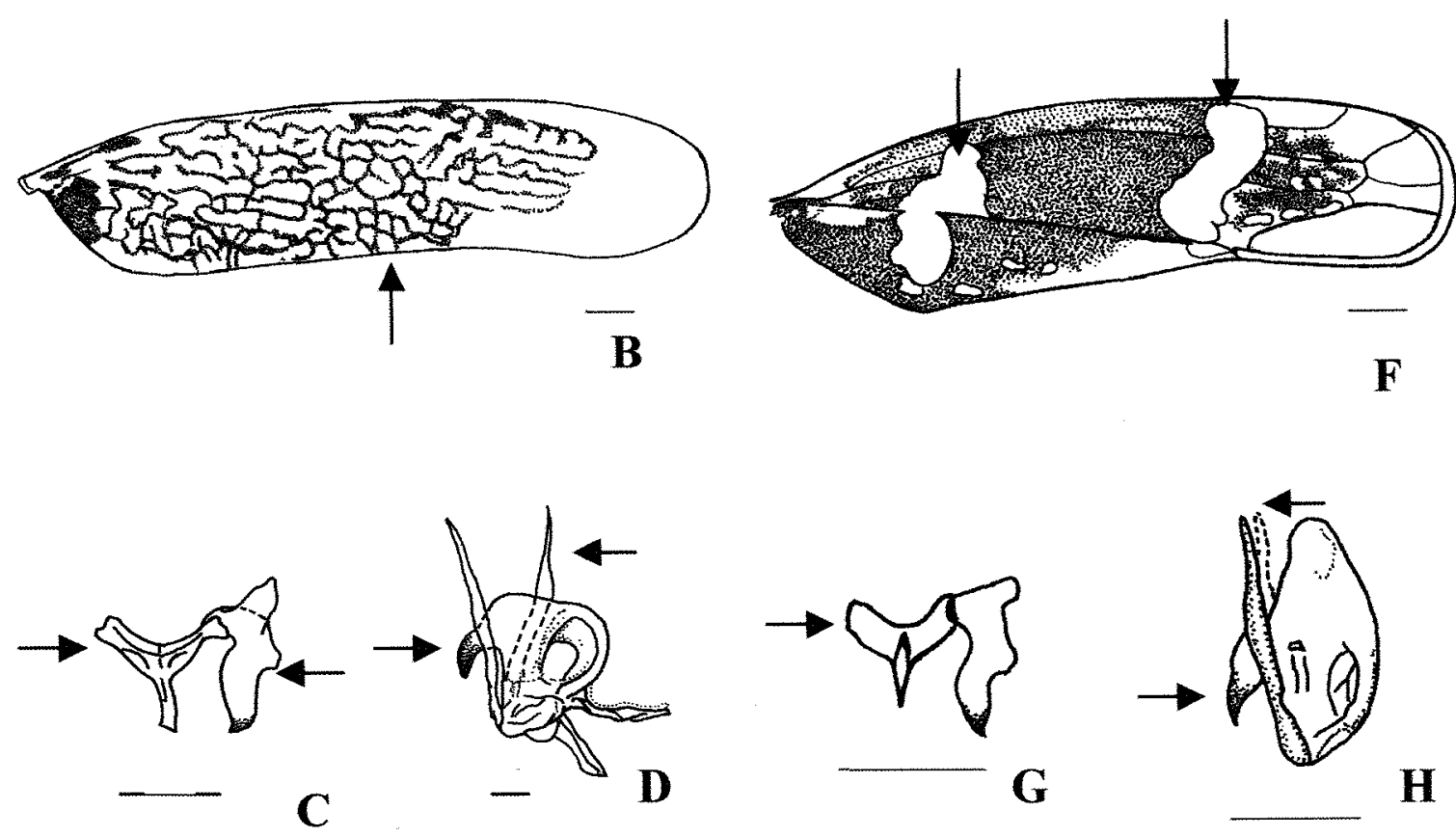

H

Figura 15 - Macugonalia cavifrons (A) cabeça, protonoto e escutelo (vista dorsal); (B) asa anterior; (C) conectivo e estilo (vista dorsal); (D) edeago (vista lateral). Macugonalia leucomelas (E) cabeça, pronoto e escutelo (vista dorsal); (F) asa anterior; $(\mathrm{G})$ conectivo e estilo (vista dorsal); $(\mathrm{H})$ edeago (vista lateral) (escalas A, B e F: 0,4 mm; E: 0,5 mm; C, G e H: 0,25 mm; D: 0,16 mm). 
Genitália do macho: Processos do pigóforo iniciando-se na margem ventral, antes do ápice (Fig. 16D); edeago espesso em vista dorsal, assimétrico, com processos na forma de espinhos dispostos irregularmente e esclerotinizados no ápice, base na forma de um balão dilatado com um espinho afilado e curvo na porção final restando um ramo com 4 espinhos (Fig. 16F); conectivo em Y, com os braços amplamente divergindo e distanciando os estilos, que não se estendem além do ápice do conectivo (Fig. 16E); ausência de paráfises.

Comprimento: Machos: $11,0 \mathrm{~mm} \pm 0,41(10,5-11,5 \mathrm{~mm})$. Fêmeas: 11,65 $\mathrm{mm} \pm$ $0,41(11,0-12,0 \mathrm{~mm})$.

Diagnose: Clípeo extremamente dilatado, convexo; coloração arroxeada do corpo com uma série de manchas escuras; edeago assimétrico e com espinhos dipostos irregularmente e esclerotinizados no ápice.

Nota Taxonômica: Espécie muito relacionada à $O$. expansa Melichar, sendo inclusive considerada sinonímia por Schröder (1959) e Young (1977). São separadas pela disposição dos cinco espinhos no edeago Schröder (1962).

Distribuição Geográfica: Colômbia, México, Equador, Bolívia, Brasil (SP, SC), Paraguai (Young, 1968; Metcalf, 1965; Zanol \& Menezes, 1982), Argentina (Coll, 1996).

Hospedeiros: Citros (Citrus sinensis L. Osbeck), vegetação espontânea do pomar (Coll, 1996), cambará (Lantana camara L. ) (Young, 1968).

Material: BRASIL. São Paulo: Bebedouro, 04/VII/1997 (R. Krügner), 4 machos (ESALQ); 09/VII/1997 (R. Krügner), 5 machos (ESALQ); 14/V/1997 (S. Roberto), 2 fềmeas (ESALQ); III/1997 (S. Roberto), 5 machos (ESALQ); 09/V/1997 (T. A. Giustolin), 1 fêmea (ESALQ); 09/V/1997 (T. A. Giustolin), 1 Macho (ESALQ); Monte Azul Paulista, 28/V/1998 (T. A. Giustolin), 8 machos (ESALQ); Turvínia, 11/IX/1997 (T. A. Giustolin), 1 macho (ESALQ).

Comentários: O gênero Oncometopia juntamente com Dichropheps Stål, Egidemia China, Homalodisca Stål, Phera Stål, Propetes Walker, Pseudophera Melichar e Cleusina Cavichioli \& Sakakibara apresentam o metepímero com uma projeção angular, onde as tégminas se encaixam quando em repouso (Young, 1968; Cavichioli \& Sakakibara, 1989). O edeago de Oncometopia pode variar inter e intra-especificamente 
(Young, 1968), podendo haver uma variação na posição e no tamanho dos espinhos do edeago dessa espécie (Schröder, 1959; Emmrich, 1975). O gênero Oncometopia é muito relacionado ao gênero Homalodisca, que também ocorre em citros, sendo separado externamente, principalmente pela presença de um clípeo bastante convexo (Young, 1968). O. facialis localiza-se e realiza sua alimentação em ramos mais desenvolvidos, mas não completamente lenhosos. Dificilmente ocorrem em ramos novos com brotações recentes e são mais facilmente encontrados em ramos eretos. Fêmeas dessa espécie, no período de oviposição apresentam duas manchas esféricas, brancas e convexas sobre as asas anteriores, o mesmo sendo também observado em fềmeas de Homalodisca ignorata Melichar. Os ovos são depositados lado a lado sob a epiderme da folha em uma única camada e recobertos por uma substância branca (Yamamoto \& Roberto, 1997). Predominantemente, sua oviposição localiza-se na face inferior da folha e a fase jovem dura em média 76 dias, sob temperatura flutuante (Almeida e Lopes, 1997). Espécie constante em pomares cítricos, floresta hidrofólia, brejo e cerrado, também ocorrendo em canavial e cafeeiro.

\section{Plesiommata corniculata Young, 1977}

Cabeça: Coloração amarelo-pálida com uma estreita borda ou círculo preto ao redor de cada ocelo e com uma mancha da mesma cor entre a área mediana da coroa e o ápice (Fig. 17A); coroa com o ápice arredondado em vista dorsal; face irregularmente mesclada com áreas marrom-claras e escura na lateral, com uma área mediana mais clara; impressões musculares distintas.

Tórax: Largura do pronoto menor que a largura transocular da cabeça; asas anteriores hialinas, com nervuras longitudinais marrom salientes, com duas das três células anteapicais e pelo menos duas células apicais abertas na base (Fig. 17B); pronoto com duas faixas transversais amarronzadas (variável intraespecificamante); fórmula setal do fêmur posterior 2.1.1; comprimento do basitarso maior ou do mesmo tamanho que a soma do comprimento dos distais, com duas fileiras paralelas de cerdas na superfície plantar. 

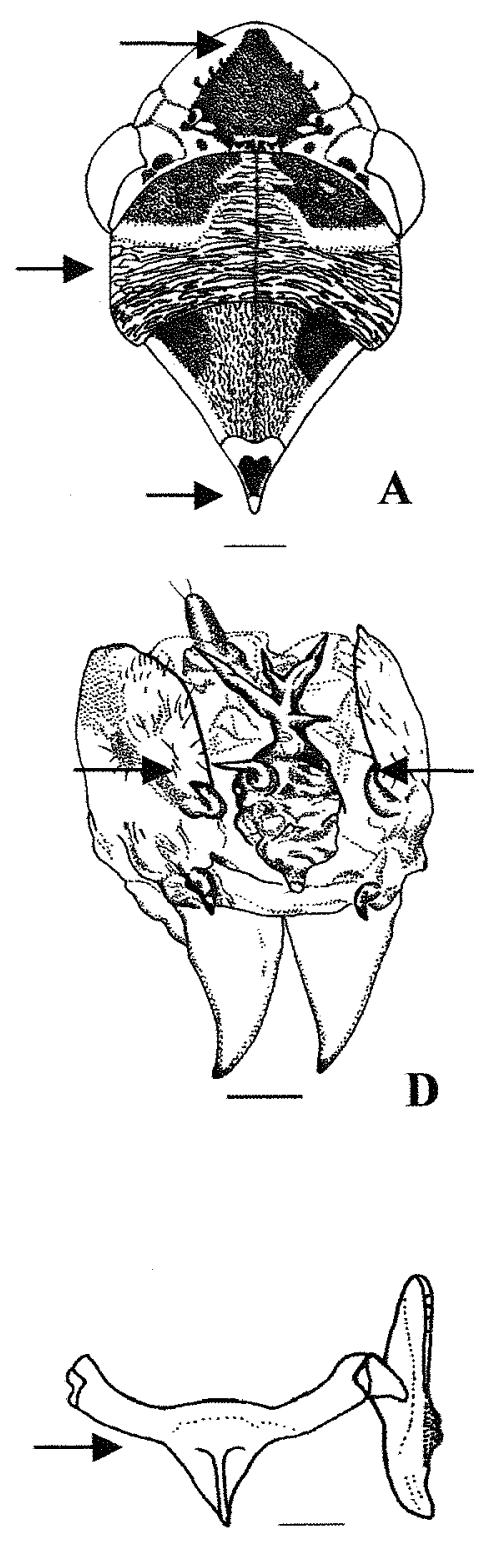

$\mathbf{E}$

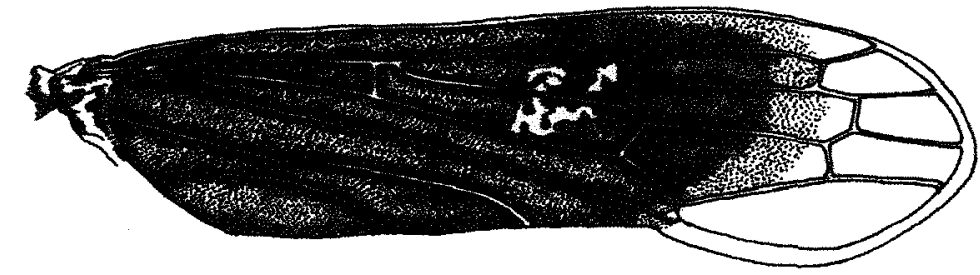

B
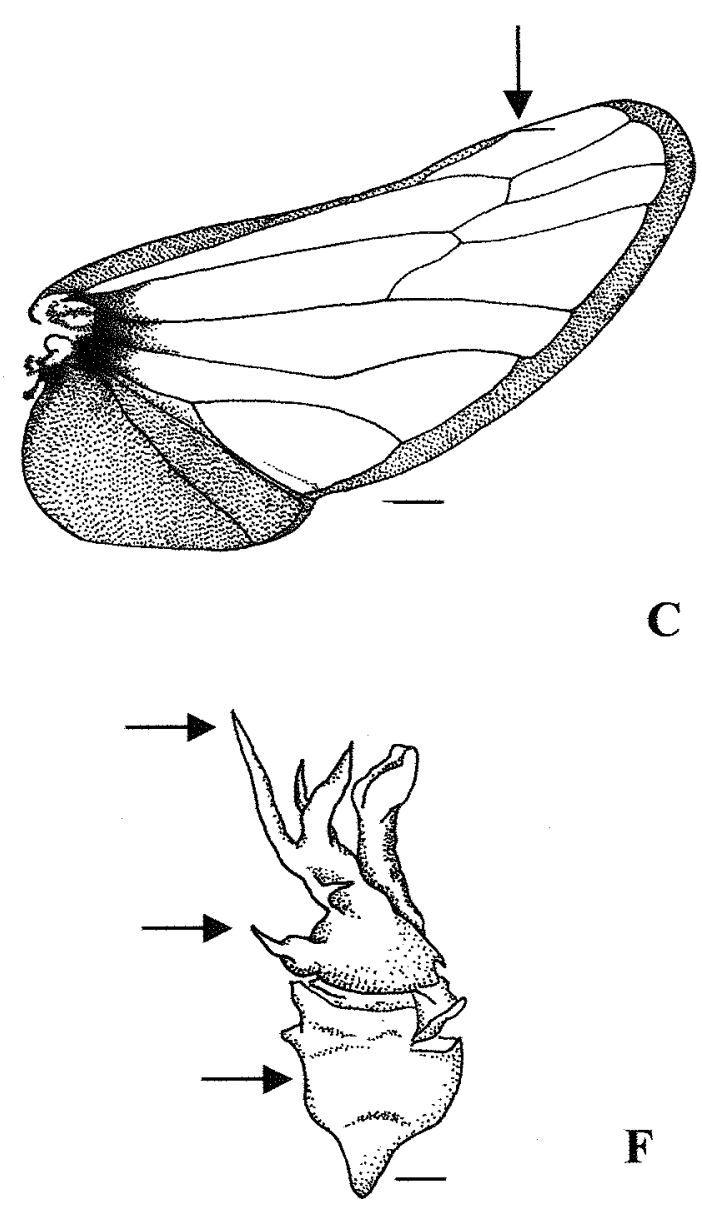

$\mathbf{F}$

Figura 16 - Oncometopia facialis (A) cabeça, pronoto e escutelo (vista dorsal); (B) asa anterior; (C) asa posterior; (D) pigóforo e edeago (vista ventral); (E) conectivo e estilo (vista dorsal); (F) edeago (vista lateral) (escalas: A, B, C e D: $0,5 \mathrm{~mm}$; E: $0,2 \mathrm{~mm}$; F: $0,25 \mathrm{~mm}$ ). 
Genitália do macho: Placas subgenitais gradualmente cônicas na metade basal, afinandose na metade apical (Fig. 17C); edeago pequeno expandido no ápice (Fig. 17F), em vista ventral se assemelha a uma taça (Fig. 17E); processos do edeago (1 par) iniciando-se ventralmente na base e estendendo-se dorsalmente sobre a haste; conectivo em $\mathrm{Y}$, com os braços mais curtos do que a haste, estilo estendendo-se posteriormente ao ápice do conectivo e apresentando nitidamente um lobo préapical (Fig. 17D); paráfises ausentes. Comprimento: Machos: 3,99 mm \pm 0,12 (3,8-4,15 mm).

Diagnose: Cabeça com uma mancha preta na forma variável entre a porção mediana da coroa e o ápice; edeago pequeno e bastante expandido no ápice, em vista lateral.

Nota Taxonômica: O gênero Plesiommata é relacionado ao gênero Ciminius Metcalf \& Bruner, mas difere marcadamente deste pela falta de paráfises. $P$. corniculata é separada de todas as espécies do gênero pela distinta forma do edeago. Espécie muito semelhante externamente a $P$. mollicella (Fowler, 1900), que também foi coletada em pomar cítrico na Argentina (Coll, 1996).

Distribuição Geográfica: México, Costa Rica, Panamá, Colômbia, Trinidad, Granada, Venezuela, Guiana, Bolívia, Equador, Paraguai e Brasil ( BA, MT, SP, RS, RR, MG) (Young, 1977; Zanol \& Menezes, 1982; Cavichioli \& Zanol, 1991; Coelho, 1997).

Hospedeiros: Citros (Citrus sinensis L. Osbeck), vegetação espontânea do pomar (Coll, 1996), braquiária (Brachiaria decumbens Stapf.), capim-buffel (Cenchrus ciliaris L. cv. Biloela), capim-cuiabano (Paspalum plicatulum Michx), capim-de-rhodes (Chloris gayana Kunth), capim-estrela (Cynodon plectostachyum Pielger), carrapicho-beiço-de boi (Desmodium intortum Urb.), green-panic (Panicum maximum Jacq. cv. Green Panic), hemátria (Hemathria altissima (Poir.) Staff. \& C.E. Hubbard), capim-jaraguá (Hyparrhenia rufa (Ness) Stapf.), jetirana (Centrosema pubescens Benth), pangola (Digitaria swazilandensis Stent; $D$. decumbens Stent cv. Transvala; D. decumbens Stent), setaria-nandi (Setaria anceps cv. Nandi), soja-perene (Glycine wightii (Wir. Grah ex Wight \& And. Arn.) Verd. Court) (Zanol \& Menezes, 1982), batata-doce (Ipomoea batatas Lam.) e gramíneas (Young, 1977).

Material: BRASIL. São Paulo: Bebedouro, 04/VII/1997 (T. A. Giustolin), 1 macho (ESALQ); 15/VIII/1997 (T. A. Giustolin), 1 macho (ESALQ); Piracicaba, 28/V/1998 (P. 
Milano), 1 macho (ESALQ); Turvínia, 26/IX/1997 (T. A. Giustolin), 7 machos (ESALQ); 18/VI/1997 (T. A. Giustolin), 3 machos (ESALQ); Ribeirão Preto, 04/VIII/1998 (S. Lopes), 3 machos (ESALQ).

Comentários: Segundo Gravena et al. (1997), esta é a espécie mais facilmente encontrada em gramíneas, com pouca presença na planta cítrica. Fêmeas dessa espécie não foram identificadas, em função da dificuldade de separação das espécies $P$. corniculata de $P$. mollicella por caracteres externos. Foi uma das espécies mais abundantes na Mata Atlântica (Viçosa-MG), durante a estação chuvosa (Coelho, 1997). Nas amostragens, essa espécie foi coletada nas plantas invasoras dos pomares, principalmente gramíneas (grama-seda e capim braquiária).

\section{Plesiommata mollicella (Fowler, 1900)}

Cabeça: Coloração amarelo-pálida com uma mancha preta de forma variável entre a área mediana da coroa e o ápice, com uma série de manchas mais escuras dispostas desordenadamente em vista dorsal (variável intraespecificamente); margem anterior convexa (Fig. 17G); face estreita; clípeo pequeno. Demais características semelhante à P. corniculata.

Genitália do macho: Semelhante à $P$. corniculata, exceto pelo edeago, cuja haste, em vista lateral, apresenta uma expansão dorsal de cada lado próximo ao comprimento mediano (Fig. 17H e 17I).

Comprimento: Machos: 4,58 mm $\pm 0,24(5,0-4,25 \mathrm{~mm})$. Fêmea: $5,29 \mathrm{~mm} \pm 0,25(5,75-$ $5,0 \mathrm{~mm})$.

Diagnose: Edeago, em vista lateral, com uma expansão dorsal de cada lado próximo ao comprimento mediano.

Nota Taxonômica: Young ilustrou o macho de Tettigonia mollicella Fowler em sua revisão sobre a Tribo Cicadellini por comparação com o lectótipo (fềmea). Segundo Osborn (1926), essa espécie é semelhante à $P$. tripunctata, mas difere desta pela presença de uma mancha grande na área central do vértice. 
Distribuição Geográfica: México, Honduras, Guatemala, Costa Rica, Panamá, Colômbia, Venezuela, Guiana Francesa, Bolívia, Equador, Paraguai, Brasil (SP, SC) e Argentina (Young, 1977; Zanol \& Menezes, 1982; Coll, 1996).

Hospedeiros: Citros (Citrus sinensis L. Osbeck), vegetação espontânea do pomar (Coll, 1996), grama (Young, 1977; Zanol \& Menezes, 1982).

Material: BRASIL. São Paulo: Piracicaba, 07/II/1998 (R. Krügner), 15 machos e 13 fềmeas (ESALQ); 13/III/1998 (R. Krügner), 11 machos e 1 fềmea (ESALQ); Monte Azul Paulista, 01/V/1998 (R. Krügner), 2 machos (ESALQ); Ribeirão Preto, 04/VIII/1998 (S. Lopes), 6 machos e 2 fềmeas (ESALQ); Turvínia, 22/I/1998 (T. A. Giustolin), 5 machos (ESALQ).

Comentários: Foi coletada em um número bem maior que $P$. corniculata na vegetação espontânea do pomar e em gramíneas, predominantemente. As fềmeas nesse caso foram consideradas com sendo de $P$. mollicella, pois nas coletas, todos os machos pertenciam a essa espécie.

\subsection{Ninfas}

\section{Acrogonia sp.}

Primeiro ínstar: Coloração geral clara, com as margens laterais e as subdivisões do corpo apresentando bordas escurecidas (marrom), além de duas faixas longitudinais escuras que partem da margem posterior paralelas e divergem no ápice da cabeça; esta, pouco mais larga que longa; margem anterior arredondada e afinada no ápice; lóbulos suprantenais não salientes; antenas desenvolvidas, compridas, afinando-se para o ápice progressivamente, situadas entre os olhos. Olhos ovalados, bem desenvolvidos e salientes; mais longos que largos. Clípeo distinto. Anteclípeo não distintamente separado do clípeo, triangular, com a linha de perfil continuando a do clípeo. Ápice do rostro ultrapassando a base das coxas II. Pronoto retangular, pouco mais estreito que a cabeça e mais longo que o mesonoto; este com a margem lateral menor que o lobo mediano. Metanoto bem mais longo que a soma do comprimento do pronoto e mesonoto. Pernas 

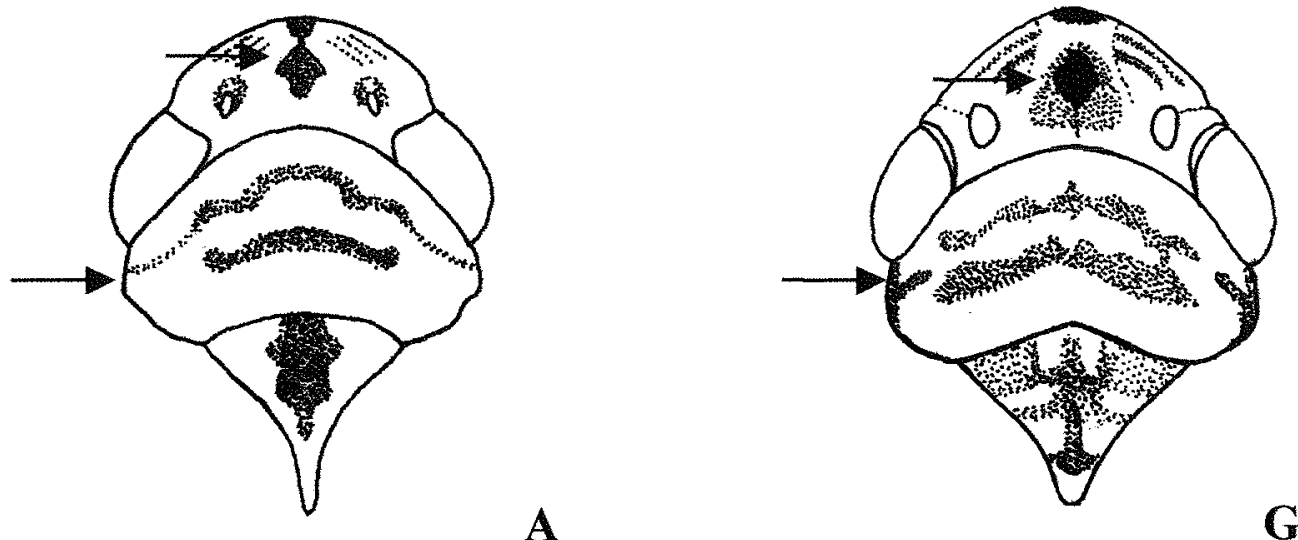

A

G

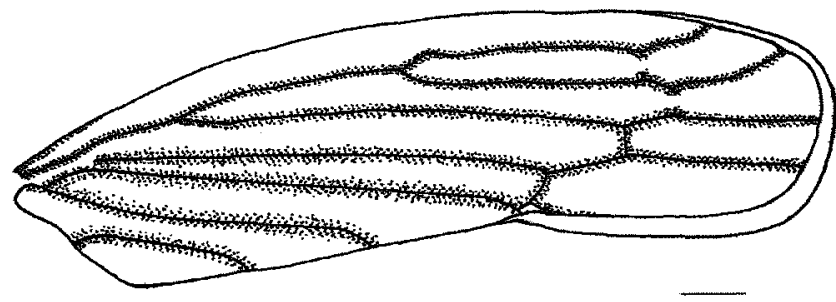

B

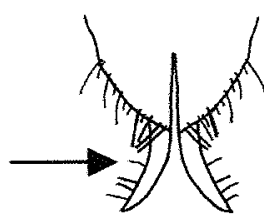

$\mathbf{C}$
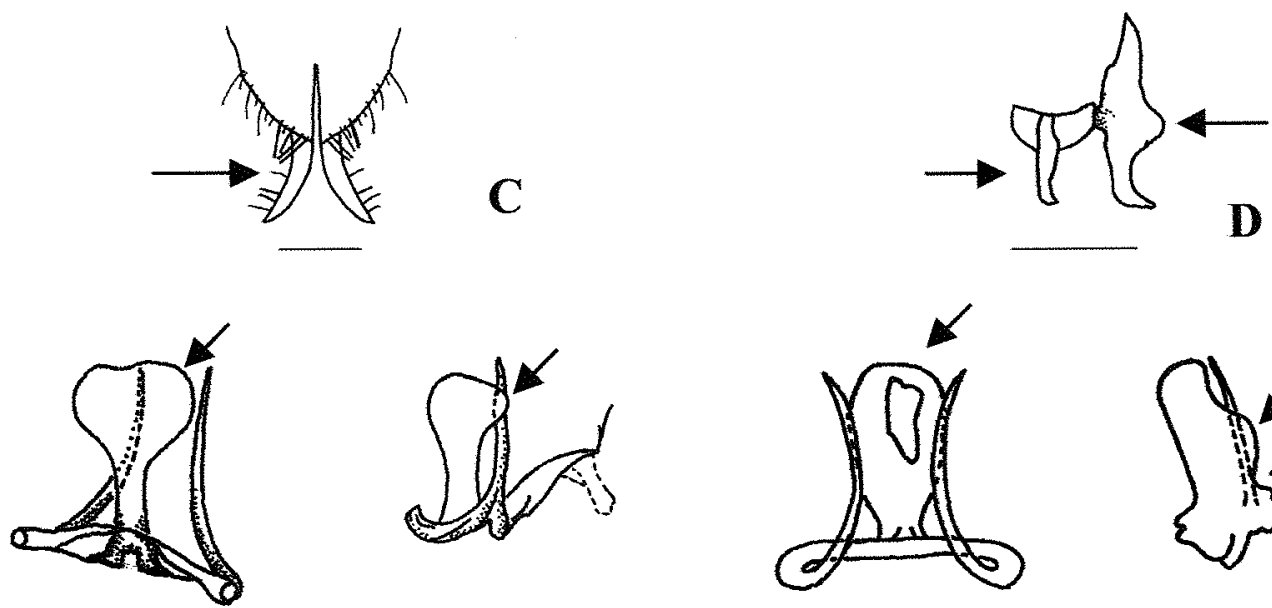

$\mathbf{E}$
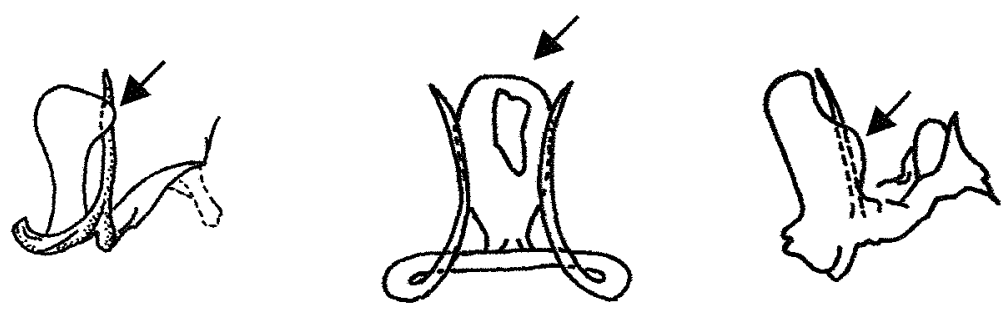

H

\section{I}

Figura 17 - Plesiommata corniculata (A) cabeça, pronoto e escutelo (vista dorsal); (B) asa anterior; (C) placa subgenital (vista ventral); (D) conectivo e estilo (vista dorsal); (E) edeago (vista ventral); (F) edeago (vista lateral). Plesiommata mollicella $(\mathrm{G})$ cabeça, pronoto e escutelo (vista dorsal); $(\mathrm{H})$ edeago (vista ventral); (I) edeago (vista lateral) (escalas A, B: 0,5 mm; C, D, F, H e I: 0,2 $\mathrm{mm}$; E: 0,1 mm; G: 0,25 mm). 
normais; metatíbias com espinhos dispostos em fileiras; tarsos dímeros, com tarsômeros aproximadamente do mesmo tamanho nas pernas metatorácicas; basitarsos das pernas pro e mesotorácicas menores que os distais, todos terminando em um par de garras. Abdome com 8 segmentos bem visíveis, o primeiro visível reduzido em relação aos demais. Ventralmente, o abdome apresenta uma abertura longitudinal na extremidade, logo abaixo do ânus (Fig. 18A).

Segundo ínstar: Coloração geral levemente mais intensa que a do primeiro ínstar, pouca esclerotinizada. Cabeça pouco mais larga que longa, margem anterior arredondada e afilada no ápice; lóbulos suprantenais não muito salientes em vista dorsal, cobrindo parcialmente a base das antenas; estas bem desenvolvidas, apresentando escapo e pedicelo distintos, mais largos que os demais artículos; antenas situadas entre os olhos, sob os lóbulos suprantenais. Olhos ovalados, mais longos que largos. Clípeo distinto. Anteclípeo não separado nitidamente do clípeo, triangular, com a linha de perfil em continuação à do clípeo. Ápice do rostro ultrapassando a base das coxas II. Pronoto retangular, mais largo que longo, com margem anterior e posterior levemente arqueada. Mesonoto com os ângulos látero-posteriores expandidos, sobrepondo o terço anterior do metanoto e este cobrindo levemente a base dos três primeiros segmentos abdominais, caracterizando o início do desenvolvimento dos brotos alares. Não há uma divisão muito nítida entre os três segmentos torácicos. Abdome com nove segmentos visíveis, considerando-se que o $1^{\circ}$ e $2^{\circ}$ segmentos estão fundidos e o $11^{\circ}$ é muito reduzido, formando com o $10^{\circ}$ o tubo anal. Pernas e tarsos como no ínstar anterior; espinhos da metatíbia mais desenvolvidos. Ventralmente, o abdome é sulcado longitudinalmente (Fig. 18B).

Terceiro ínstar: Coloração geral levemente mais intensa e menos translúcida que no ínstar anterior. Cabeça um pouco mais larga que longa, margem anterior arredondada e afinada no ápice; lóbulos suprantenais salientes, em vista dorsal, cobrindo a base das antenas; estas bem desenvolvidas; escapo e pedicelo mais largos que os demais antenômeros. Antenas situam-se entre os olhos e abaixo dos lóbulos suprantenais. Olhos ovalados, mais longos que largos. Clípeo distinto, inflado. Anteclípeo não distintamente separado do clípeo, triangular, com a linha de perfil seguindo a do clípeo. Rostro 
atingindo a base das coxas II. Pronoto retangular, mais largo que longo, com margens anterior e a posterior arqueadas. Mesonoto com ângulos látero-posteriores expandidos, sobrepondo-se a metade anterior do metanoto; este também com ângulos láteroposteriores expandidos encobrindo levemente a base do $4^{\mathbf{o}}$ segmento abdominal. Pernas e tarsos como nos ínstares anteriores. Abdome com nove segmentos distintos. No $8^{0}$ e $9^{0}$ esternitos aparecem as valvas que posteriormente constituirão a genitália, sendo possível diferenciar os dois sexos (Fig. 18C).

Quarto ínstar: Coloração geral levemente mais intensa e menos translúcida que no ínstar anterior. Cabeça levemente mais larga que longa; margem anterior arredondada e afinada no ápice; lóbulos suprantenais salientes, ocultando a base das antenas; escapo e pedicelo mais largos que os demais artículos. Antenas situam-se à frente dos olhos e abaixo dos lóbulos suprantenais. Olhos ovalados, mas longos que largos. Clípeo distinto, muito mais longo que largo. Anteclípeo distintamente separado do clípeo, triangular, com a linha do perfil seguindo a do clípeo. Ápice do rostro atingindo a base das coxas II. Segmentos torácicos e abdominais nítidos. Pronoto retangular, três vezes mais largo que longo, margem anterior levemente arqueada e a posterior emarginada medianamente. Mesonoto com os ângulos látero-posteriores expandidos, sobrepondo mais da metade dos brotos alares do metanoto; este com os ângulos látero-posteriores expandidos até a metade do $4^{\circ}$ segmento abdominal, encobrindo parcialmente os três primeiros segmentos abdominais. Pernas, tarsos e abdome semelhantes ao dos ínstares anteriores. Genitália bem evidente e esclerotinizada (Fig. 18D).

Quinto ínstar: Coloração geral mais intensa que nos demais ínstares. Cabeça pouco mais larga que longa, margem anterior arredondada com o ápice afinado; lóbulos suprantenais salientes, cobrindo a base das antenas; escapo e pedicelo mais largos que os demais artículos; antenas situam-se entre os olhos sob os lóbulos suprantenais. Olhos ovalados, mais longos que largos; ocelos levemente visíveis em uma área arredondada levemente mais clara, situados próximos ou na linha imaginária que tangencia as bordas anteriores dos olhos. Clípeo distinto e inflado. Anteclípeo nitidamente separado do clípeo, triangular, com a linha de perfil seguindo a do clípeo. Ápice do rostro atingindo a base das coxas II. Pronoto mais largo que longo, com a margem anterior arqueada e a 
posterior emarginada medianamente. Mesonoto tão largo quanto o pronoto, na região mediana da margem posterior, forma um pequeno triângulo sobre o metanoto, caracterizando o escutelo; brotos alares do mesonoto cobrindo quase que inteiramente as do metatórax e com uma área opaca delimitada por uma pequena porção membranosa no ápice. Metanoto com os brotos alares estendidos até a metade do $5^{\circ}$ segmento abdominal. Pernas normais, com espinhos dispostos em fileiras; metatarsos trímeros (não muito nítidos) e os demais dímeros. Abdome com nove segmentos visíveis. Genitália bem desenvolvida, distinguindo-se perfeitamente os sexos (Fig. 18E).

Comentários: O primeiro ínstar difere dos demais pela presença de faixas escurecidas (marrom) nas margens laterais e subdivisões do corpo e de oito segmentos abdominais visíveis. No segundo ínstar, há uma leve expansão dos ângulos látero-posteriores dos segmentos meso e metatorácicos, sendo que os do meso sobrepõem o terço anterior do metanoto e este cobre levemente a base dos três primeiros segmentos abdominais, caracterizando o início do desenvolvimento dos brotos alares. A partir deste ínstar, nove segmentos abdominais são visíveis. $\mathrm{O}$ terceiro ínstar caracteriza-se principalmente pelo desenvolvimento das valvas no oitavo e nono escleritos abdominais, caracterizando o desenvolvimento da genitália; além de haver um maior desenvolvimento dos brotos alares do mesonoto que atingem mais da metade do metanoto e estes cobrem levemente a base do $4^{0}$ segmento abdominal. No quarto ínstar os brotos alares do mesonoto sobrepõem mais da metade dos brotos alares do metanoto, estes se expandem até a metade do $4^{0}$ segmento abdominal e a genitália é muito mais visível que no ínstar anterior. O quinto ínstar caracteriza-se pelos ocelos levemente visíveis, em uma área arredondada levemente clara; metatarsos trímeros; brotos alares do mesonoto cobrem quase que inteiramente os do metanoto, escutelo nítido e genitália bastante esclerotinizada. As medidas para os cinco ínstares ninfais de Acrogonia sp. estão na Tabela 1. 
Tabela 1. Média ( $(D P)$ e amplitude, em milímetros, de diversos parâmetros dos estágios ninfais de Acrogonia sp., criados em mudas cítricas (Citrus sinensis L.).

\begin{tabular}{lccccc}
\hline Medidas (mm) & \multicolumn{5}{c}{ Ínstares } \\
\cline { 2 - 6 } & $1^{\underline{0}}$ & $2^{\underline{0}}$ & $3^{\underline{0}}$ & $4^{\underline{0}}$ & $5^{\underline{0}}$ \\
\hline Largura da cabeça & $0,72 \pm 0,11$ & $0,96 \pm 0,10$ & $1,20 \pm 0,04$ & $1,56 \pm 0,0$ & $1,91 \pm 0,07$ \\
& $(0,47-0,78)$ & $(0,78-1,16)$ & $(1,13-1,25)$ & $(1,56)$ & $(1,81-2,03)$ \\
Comprimento da cabeça & $0,61 \pm 0,03$ & $0,86 \pm 0,09$ & $1,13 \pm 0,06$ & $1,36 \pm 0,09$ & $1,59 \pm 0,06$ \\
& $(0,56-0,63)$ & $(0,78-1,09)$ & $(1,03-1,25)$ & $(1,25-1,44)$ & $(1,53-1,68)$ \\
Largura do pronoto & $0,66 \pm 0,08$ & $0,88 \pm 0,08$ & $1,14 \pm 0,05$ & $1,44 \pm 0,03$ & $1,78 \pm 0,20$ \\
& $(0,50-0,72)$ & $(0,75-1,03)$ & $(1,06-1,22)$ & $(1,41-1,47)$ & $(1,44-2,03)$ \\
Comprimento cabeça-tórax & $1,09 \pm 0,10$ & $1,44 \pm 0,13$ & $2,37 \pm 0,15$ & $2,60 \pm 0,18$ & $3,70 \pm 0,20$ \\
& $(0,94-1,25)$ & $(1,28-1,78)$ & $(2,22-2,53)$ & $(2,34-2,81)$ & $(3,38-3,91)$ \\
Comprimento total & $2,05 \pm 0,22$ & $2,76 \pm 0,23$ & $5,06 \pm 0,40$ & $5,84 \pm 0,34$ & $7,90 \pm 0,48$ \\
& $(1,81-2,47)$ & $(2,34-3,09)$ & $(4,44-5,72)$ & $(5,25-6,09)$ & $(7,22-8,44)$ \\
\hline
\end{tabular}

\section{Dilobopterus costalimai Young, 1977}

Primeiro ínstar: Coloração geral amarelo-clara, com aumento de intensidade da cor nas áreas de segmentação do corpo. Cabeça mais larga que longa, com as margens anteriores arredondadas e duas manchas pouco mais escuras, entre os olhos, próximas à margem posterior; lóbulos suprantenais não-salientes em vista dorsal; escapo e pedicelo distintos em função de suas maiores larguras. Clípeo distinto, com uma mancha alongada escurecida na base e com duas faixas amarronzadas na margem lateral; impressões musculares levemente salientes. Anteclípeo fracamente separado do clípeo, triangular, com a linha de perfil acompanhando a do clípeo. Rostro com três segmentos, ultrapassando a base das coxas II. Pronoto retangular, mais estreito que a cabeça. Comprimento do mesonoto menor que o comprimento do pronoto, com os ângulos látero-posteriores menores que o lobo mediano. Metanoto maior que o comprimento do pro e mesonoto juntos. Pernas normais, com as tíbias posteriores revestidas por fileiras de espinhos; tarsos dímeros, nas pernas posteriores, os tarsômeros têm o mesmo 

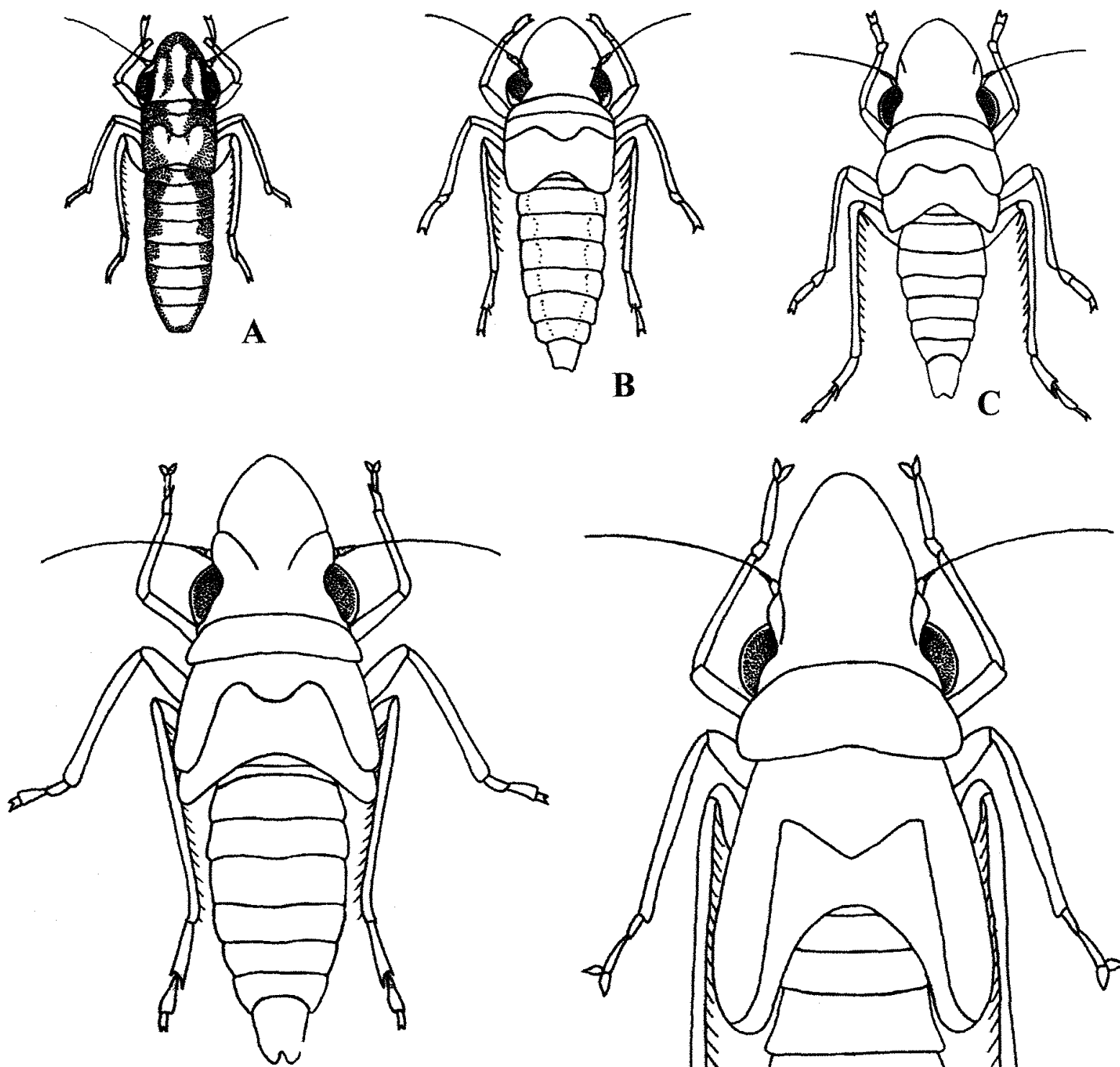

D

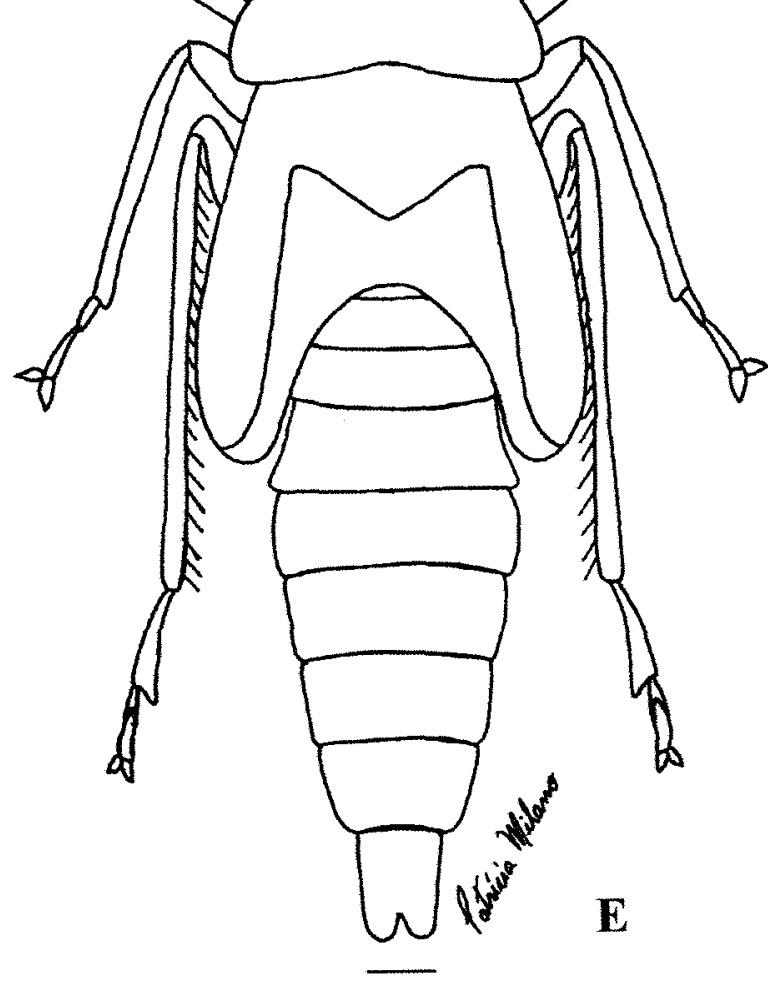

Figura 18 - Ninfas de Acrogonia sp., vista dorsal: (A) $1^{0}$ instar; (B) $2^{\circ}$ ínstar; (C) $3^{0}$ ínstar; (D) $4^{\circ}$ ínstar; (E) $5^{\circ}$ ínstar (escala: 0,4 mm). 
tamanho, e nas anteriores e medianas o basitarso é reduzido. Abdome com nove segmentos visíveis, o $1^{\underline{0}}$ fundido ao $2^{\underline{0}}$ e mais curto que os demais; o $11^{\underline{0}}$ muito reduzido, formando com o $10^{0} \mathrm{o}$ tubo anal. $\mathrm{O}$ abdome é sulcado ventro-longitudinalmente, com uma abertura logo abaixo do ânus (Fig. 19A).

Segundo ínstar: Coloração amarela levemente mais forte que a do primeiro ínstar e segmentação do corpo nítida. Cabeça mais larga que longa, com a margem anterior arredondada, com duas manchas escuras, entre os olhos, próximas à margem posterior lóbulos suprantenais não-salientes, em vista dorsal; antena desenvolvida com os artículos decrescentes no tamanho da base para o ápice; escapo e pedicelo largos. Clípeo distinto, com uma mancha alongada escura na base e uma faixa marron-clara nas margens laterais. Anteclípeo distintamente separado do clípeo, triangular, com a linha de perfil em continuação com a do clípeo. Rostro com três segmentos e o ápice ultrapassando a base das coxas II. Pronoto retangular, mais largo que longo, com a margem anterior e a posterior levemente arqueadas. Mesonoto levemente expandido nos ângulos latero-posteriores, com os brotos alares do mesmo comprimento que o lobo mediano; metanoto maior que o pronoto e o mesonoto. Pernas normais, metatíbias com fileiras de espinhos; tarsos dímeros, mantendo o mesmo padrão de tamanho observado no ínstar anterior. Abdome como no ínstar anterior, porém com coloração e segmentação mais intensa (Fig. 19B).

Terceiro ínstar: Coloração amarelo-alaranjada, mais intensa do que nos ínstares anteriores e início de aparecimento de linhas escuras, amarronzadas no tórax. Cabeça mais larga que longa, com a margem anterior arredondada e duas manchas escuras bem nítidas, entre os olhos e próximos a margem posterior; lóbulos suprantenais nãosalientes, em vista dorsal; impressões musculares salientes, em vista dorsal; antenas bem desenvolvidas, com escapo e pedicelo largos. Olhos ovalados, mais longos que largos. Clípeo distinto, inflado, com duas faixas laterais marrom-claras e uma mancha alongada escura na base. Anteclípeo distintamente separado do clípeo, triangular, com a linha de perfil seguindo a do clípeo. Ápice do rostro atingindo a base das coxas II. Pronoto retangular, mais largo que longo, margens anteriores arqueadas $\mathrm{e}$ as posteriores emarginadas medianamente, com borda mais escura na margem anterior. Mesonoto com 
as bordas escurecidas nas margens anteriores e posteriores, com os ângulos láteroposteriores expandidos, sobrepondo-se ao terço anterior do metanoto, estes também com o ângulos látero-posteriores expandidos, encobrindo levemente os dois primeiros segmentos abdominais, com manchas escuras que partem do lobo mediano do mesonoto. Pernas normais; tarsos dímeros, seguindo o mesmo padrão de tamanho dos ínstares anteriores. Metatíbias com espinhos bastante desenvolvidos dispostos em fileiras. Abdome semelhante aos ínstares anteriores, porém no $8^{0}$ e $9^{0}$ esternitos aparecem as valvas que constituirão a genitália, podendo-se diferenciar os sexos neste ínstar (Fig. 19C).

Quarto ínstar: Coloração geral amarelo-clara, menos intensa que nos ínstares anteriores, com manchas mais escuras na cabeça, tórax e abdome. Cabeça mais larga que longa, com a margem anterior arredondada; impressões musculares salientes, delimitadas em uma área com margens escuras; com duas manchas alongadas e escurecidas, entre os olhos, próximas a margem posterior; região mediana da cabeça com mancha levemente escura, na forma de M. Olhos ovalados, mais longos que largos; lóbulos suprantenais não-evidentes, em vista dorsal; antenas situadas entre os olhos, com escapo e pedicelo mais largos que os demais artículos. Clípeo distinto, com impressões musculares salientes, duas faixas escurecidas nas margens logo após a região mediana e mancha preta na base, variando de arredondada para alongada. Anteclípeo separado do clípeo, triangular, com a linha de perfil seguindo a do clípeo. Ápice do rostro atingindo a base das coxas II. Pronoto retangular, mais largo que longo, com a margem anterior arqueada, a posterior emarginada medianamente, sendo que as duas apresentam bordas escuras $\mathrm{e}$ duas manchas arredondadas equidistantes, partindo da margem anterior. Mesonoto com os ângulos látero-posteriores expandidos até mais da metade do metanoto; estes com os ângulos látero-posteriores atingindo a base do terceiro segmento abdominal. Meso e metanoto com margens escurecidas e manchas mais escuras. Abdome com nove segmentos visíveis e faixas longitudinais, partindo da base em direção ao ápice. Pernas normais, com as tíbias posteriores revestidas de espinhos dispostos em fileiras; tarsos dímeros, terminando em duas garras no ápice, seguindo o mesmo padrão de tamanho dos 
tarsômeros dos ínstares anteriores. Abdome semelhante ao dos ínstares anteriores, com a genitália bem mais evidente e esclerotinizada (Fig. 19D).

Quinto ínstar: Coloração geral amarela ou alaranjada com manchas e bordas escuras mais evidentes. Em vista ventral, ausência de manchas escuras. Cabeça quase duas vezes mais larga que longa; impressões musculares salientes em uma área delimitada por bordas escurecidas; antenas como nos instares anteriores; área mediana da cabeça com mancha levemente escurecida na forma da letra $\mathrm{M}$; área ocelar evidenciada por duas áreas arredondadas mais claras na linha imaginária que tangencia os ângulos oculares anteriores. Olhos ovalados, mais longos que largos. Clípeo distinto, com mancha preta na base; impressões musculares salientes e margens laterais escurecidas após a região mediana. Anteclípeo distinto, triangular, com a linha de perfil seguindo a do clípeo. Ápice do rostro atingindo a base das coxas II. Pronoto mais largo que longo, com a margem anterior arqueada e a posterior emarginada medianamente, margens escurecidas com duas manchas arredondadas equidistantes, partindo da margem anterior. Mesonoto com os bordos escurecidos, na região mediana da margem posterior, formando um pequeno triângulo sobre o metanoto, caracterizando o escutelo; brotos alares do mesonoto cobrindo quase que inteiramente os do metanoto; estes apresentando os brotos alares até a base do quarto segmento abdominal. Meso e Metanoto com áreas escurecidas formando desenhos característicos; bordas dos brotos alares escurecidas. Pernas normais, com os espinhos das tíbias posteriores bastante desenvolvidos e dispostos em fileiras; metatarsos trímeros (segmentação não muito evidente), os demais dímeros. Abdome com nove segmentos visíveis e faixas longitudinais escuras intercaladas com claras, partindo da base em direção ao ápice. Genitália como nos ínstares anteriores, sexos distintos (Fig. 19E).

Diagnóstico dos ínstares: O primeiro e o segundo ínstares são semelhantes, diferindo-se pelo tamanho e desenvolvimento dos ângulos látero-posteriores do mesonoto $\mathrm{e}$ metanoto. No primeiro ínstar, os ângulos látero-posteriores do mesonoto são mais curtos que o lobo mediano e no segundo apresentam praticamente o mesmo comprimento que o lobo mediano. No terceiro ínstar, aparecem nítidas faixas amarronzadas no tórax; os ângulos látero-posteriores do mesonoto sobrepõem metade do metanoto e o surgimento 
das valvas no $8^{0}$ e $9^{0}$ esternitos caracteriza o início do desenvolvimento da genitália. $\mathrm{O}$ quarto ínstar caracteriza-se pela presença de distitas faixas escuras no tórax e abdome; pelos ângulos látero-posteriores do mesonoto expandirem-se além da metade do metanoto, estes com os brotos alares atingindo a base do $3^{0}$ segmento abdominal e pela genitália bem mais evidente e esclerotinizada. No quinto instar as manchas e bordas escuras do corpo estão mais evidentes; escutelo surgindo na região mediana do metanoto; brotos alares do mesonoto cobrindo quase que inteiramente os do metanoto $\mathrm{e}$ os brotos alares deste atingindo quase todo o $4^{0}$ segmento abdominal; metatarsos trímeros não muito evidentes. As medidas para os cinco íntares ninfais de D. Costalimai estão na Tabela 2.

Tabela 2. Média ( $\pm D P)$ e amplitude, em milímetros, de diversos parâmetros dos estágios ninfais de Dilobopterus costalimai, criados em mudas cítricas (Citrus sinensis L.).

\begin{tabular}{lccccc}
\hline Medidas (mm) & \multicolumn{5}{c}{ Ínstares } \\
\cline { 2 - 6 } & $1^{\underline{0}}$ & $2^{\underline{0}}$ & $3^{\underline{0}}$ & $4^{\underline{0}}$ & $5^{\underline{0}}$ \\
\hline Largura da cabeça & $0,60 \pm 0,05$ & $0,73 \pm 0,05$ & $1,22 \pm 0,18$ & $1,53 \pm 0,04$ & $2,01 \pm 0,10$ \\
& $(0,56-0,68)$ & $(0,63-0,78)$ & $(0,97-1,47)$ & $(1,44-1,56)$ & $(1,91-2,16)$ \\
Comprimento da cabeça & $0,47 \pm 0,03$ & $0,52 \pm 0,06$ & $0,71 \pm 0,02$ & $0,86 \pm 0,07$ & $1,03 \pm 0,06$ \\
& $(0,41-0,50)$ & $(0,41-0,56)$ & $(0,69-0,75)$ & $(0,78-0,94)$ & $(0,91-1,13)$ \\
Largura do pronoto & $0,51 \pm 0,05$ & $0,61 \pm 0,04$ & $1,06 \pm 0,16$ & $1,32 \pm 0,06$ & $1,75 \pm 0,09$ \\
& $(0,47-0,59)$ & $(0,53-0,68)$ & $(0,84-1,28)$ & $(1,22-1,41)$ & $(1,59-1,88)$ \\
Comprimento cabeça-tórax & $0,88 \pm 0,04$ & $1,06 \pm 0,04$ & $1,68 \pm 0,33$ & $2,18 \pm 0,10$ & $2,94 \pm 0,12$ \\
& $(0,81-0,91)$ & $(1,00-1,16)$ & $(1,28-2,19)$ & $(1,97-2,31)$ & $(2,78-3,09)$ \\
Comprimento total & $1,77 \pm 0,22$ & $2,44 \pm 0,11$ & $4,03 \pm 0,59$ & $5,24 \pm 0,27$ & $6,94 \pm 0,38$ \\
& $(1,48-2,09)$ & $(2,25-2,59)$ & $(3,28-4,88)$ & $(4,72-5,59)$ & $(6,25-7,59)$ \\
\hline
\end{tabular}



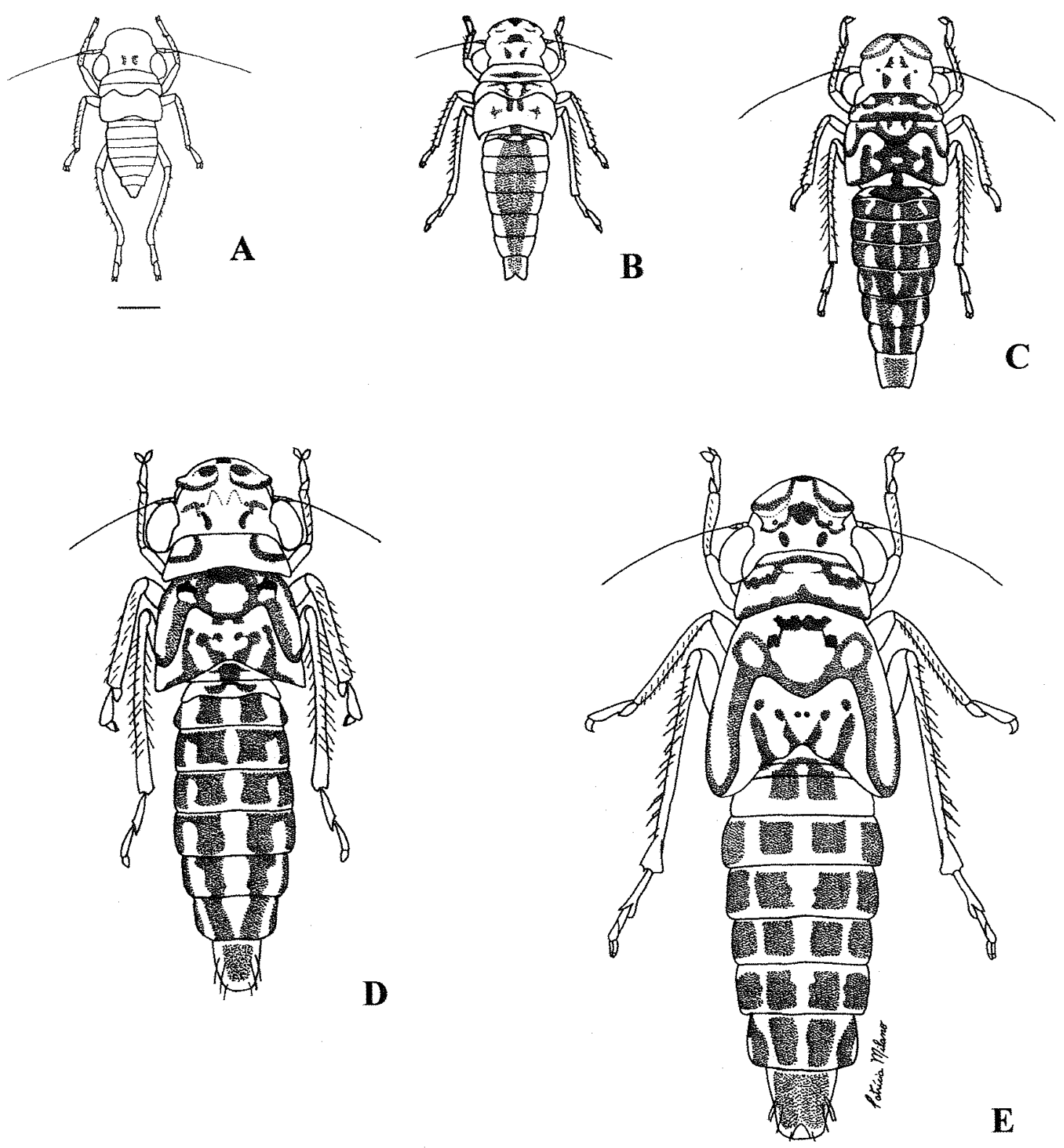

Figura 19 - Ninfas de Dilobopterus costalimai, vista dorsal: (A) $1^{0}$ instar; (B) $2^{0}$ instar; (C) $3^{\circ}$ ínstar; (D) $4^{\circ}$ ínstar; (E) $5^{\circ}$ ínstar (escalas A: 0,4 mm; B, C, D e E: $0,5 \mathrm{~mm})$. 


\section{Oncometopia facialis (Signoret, 1854)}

Primeiro ínstar: Coloração clara, logo após a eclosão, adquirindo coloração escura a seguir, com as pernas mais claras que o resto do corpo. Cabeça bem mais larga que longa, subtriangular com a margem anterior arredondada e com duas manchas escuras entre os olhos, próximas à margem posterior. Lóbulos suprantenais levemente salientes, cobrindo a base das antenas; estas com muitos artículos, sendo que estes decrescem gradualmente de tamanho da base para o ápice, situadas entre os olhos e sob os lóbulos suprantenais; escapo e pedicelo distintos dos demais antenômeros por serem mais alargados. Olhos ovalados, mais longos que largos. Clípeo distinto, bastante alargado e dilatado. Anteclípeo fracamente separado do clípeo, triangular e com a linha de perfil continuando a do clípeo; ápice do rostro ultrapassando a base das coxas II. Pronoto retangular, mais largo que longo, levemente mais estreito que a cabeça, com margens levemente arredondadas. Meso e metanoto distintamente separados. Brotos alares do mesonoto com um pequeno desenvolvimento; comprimento do mesonoto menor que o do pronoto; ângulos látero-posteriores do mesonoto menores que o lobo mediano. Pernas normais, com espinhos nas tíbias posteriores dispostos em fileiras; tarsos dímeros, o basal reduzido em relação ao distal nas pernas anteriores e medianas e praticamente do mesmo tamanho nas posteriores. Abdome com nove segmentos visíveis, sulcado ventrolongitudinalmente, com uma abertura abaixo do ânus (Fig. 20A).

Segundo ínstar: Coloração um pouco mais clara que no ínstar anterior, pernas com coloração mais clara que o restante do corpo. Cabeça mais larga que longa; subtriangular; margem anterior arredondada; com duas manchas escuras entre os olhos, próximas a margem posterior; lóbulos suprantenais salientes cobrindo a base das antenas; estas com muitos artículos que decrescem de tamanho gradativamente da base para o ápice; escapo e pedicelo distintos, mais largos que os demais artículos; antenas situadas entre os olhos e sob os lóbulos suprantenais; olhos ovalados, mais longos que largos. Clípeo distinto, bastante dilatado, impressões musculares salientes. Anteclípeo nitidamente separado do clípeo, triangular, basalmente abaulado e com a linha de perfil em continuação com a do clípeo. Pronoto retangular, mais largo que longo. Mesonoto 
menor que o pronoto, levemente expandido nos ângulos látero-posteriores, sendo que estes são do mesmo tamanho ou menores que o lobo mediano. Metanoto com a margem posterior cobrindo parcialmente os dois primeiros segmentos abdominais. Pernas normais, tíbias posteriores com espinhos dispostos em fileiras; tarsos dímeros, com tarsômeros seguindo o mesmo padrão de tamanho do ínstar anterior. O abdome sulcado ventro-longitudinalmente, apresentando uma abertura na extremidade logo abaixo do ânus (Fig. 20B).

Terceiro ínstar: Coloração menos intensa que no ínstar anterior, com as pernas mais claras que o restante do corpo. Cabeça mais larga que longa, margem anterior arredondada; com duas manchas situadas entre os olhos, próximas a margem posterior; lóbulos suprantenais salientes, cobrindo parcialmente a base das antenas; estas com vários artículos que decrescem de tamanho da base para o ápice, escapo e pedicelo mais largos, situadas entre os olhos e sob os lóbulos suprantenais; impressões musculares salientes. Olhos ovalados, mais longos que largos; clípeo distinto, bastante alargado, com impressões musculares distintas. Anteclípeo distintamente separado do clípeo, triangular, inflado na base, com a linha de perfil seguindo a do clípeo. Ápice do rostro ultrapassando a base das coxas II. Pronoto retangular, mais largo que longo, com a margem anterior arredondada e a posterior levemente emarginada. Mesonto com os ângulos látero-posteriores expandidos sobrepondo-se ao terço anterior do metanoto, este também com os ângulos látero-posteriores expandidos, cobrindo a base dos três primeiros segmentos abdominais, caracterizando o desenvolvimento dos brotos alares. Pernas normais; tarsos dímeros, seguindo o mesmo padrão de tamanho dos ínstares anteriores. Abdome com nove segmentos visíveis, com fenda ventro-longitudinal e uma abertura na extremidade logo abaixo do ânus. No oitavo e nono com as valvas em formação (Fig. 20C).

Quarto ínstar: Coloração clara. Cabeça bem mais larga que longa, margem anterior arredondada; com duas manchas escuras entre os olhos, próximo a margem posterior; lóbulos suprantenais salientes, cobrindo a base das antenas; escapo e pedicelo distintos e largos; superficie do corpo levemente pubescente; área ocelar evidente, mais clara e levemente abaulada, situada à frente da linha imaginária entre os ângulos oculares 
anteriores; olhos ovalados, mais longos que largos. Clípeo distinto, inflado na base, com impressões musculares salientes. Anteclípeo distintamente separado do clípeo, triangular, inflado na base, com a linha de perfil seguindo a do clípeo. Ápice do rostro atingindo a base das coxas II. Pronoto retangular, mais largo que longo, com margem anterior arqueada, a posterior emarginada medianamente. Mesonoto com superfície levemente pubescente; brotos alares do mesonoto sobrepondo mais da metade do broto alar do metanoto; ângulos látero-posteriores do metanoto expandidos até a metade do $4^{0}$ segmento abdominal. Pernas normais, tibias posteriores com espinhos dispostos em fileiras; tarsos dímeros, seguindo o mesmo padrão de tamanho dos ínstares anteriores. Abdome como nos ínstares anteriores, porém com a genitália bem mais evidente e esclerotinizada (Fig. 20D).

Quinto ínstar: Coloração geral bem mais clara que nos ínstares anteriores. Cabeça mais larga que longa, com as margens anteriores arredondadas e duas manchas mais escuras entre os olhos, próximas a margem posterior; lóbulos suprantenais salientes cobrindo a base das antenas; escapo e pedicelo largos; impressões musculares evidentes; face levemente pubescente; área ocelar proeminente; linha mediana da coroa evidente. Olhos ovalados, mais longos que largos. Clípeo distinto, bastante dilatado, de coloração bem mais clara que nos ínstares anteriores; porção mediana, entre as impressões musculares, com granulações. Anteclípeo distinto do clípeo, triangular, com a linha de perfil seguindo a do clípeo, levemente arqueada. Ápice do rostro atingindo a base das coxas II. Superfície do corpo com uma leve pubescência. Pronoto mais largo que longo, com a margem anterior levemente arqueada e a posterior emarginada medianamente. Mesonoto tão largo quanto o pronoto; na região mediana da margem posterior forma um pequeno triângulo que se sobrepõe ao metanoto, caracterizando o escutelo; brotos alares do mesonoto encobrindo quase que inteiramente os do metanoto. Este com os brotos alares estendendo-se até a metade do $5^{\underline{0}}$ segmento abdominal. Pernas normais; metatarsos trímeros, sendo os demais dímeros. Abdome semelhante aos demais ínstares, com a genitália bem desenvolvida, distinguindo-se perfeitamente os sexos (Fig. 20E).

Diagnóstico dos ínstares: O primeiro ínstar caracteriza-se principalmente, pela coloração escura e pelos ângulos látero-posteriores do mesonoto mais curtos ou do mesmo 
tamanho que o lobo mediano. No segundo ínstar a coloração é mais clara, havendo uma tendência de redução da intensidade de cor nos ínstares subseqüentes; os brotos alares do mesonoto são maiores que o lobo mediano. No terceiro ínstar, há o surgimento das valvas no oitavo e nono segmentos abdominais, caracterizando o desenvolvimento da genitália; os brotos alares do mesonoto sobrepõem a metade do metanoto e os deste cobrem a base dos três primeiros segmentos abdominais. O quarto instar caracteriza-se pela genitália mais distinta, área ocelar evidente e brotos alares do mesonoto sobrepõem mais da metade dos brotos alares do metanoto. No quinto ínstar, os brotos alares do mesonoto cobrem quase que inteiramente os do metanoto; o escutelo torna-se evidente, sobrepondo o metanoto. Metatarsos são trímeros e os demais dímeros. Em alguns exemplares a área ocelar já pode estar evidente a partir do $3^{0}$ ínstar. As medidas para os cinco ínstares ninfais de $O$. facialis estão na Tabela 3.

Tabela 3. Média ( $\pm D P)$ e amplitude, em milímetros, de diversos parâmetros dos estágios ninfais de Oncometopia facialis, criados em mudas cítricas (Citrus sinensis L.).

\begin{tabular}{lccccc}
\hline Medidas (mm) & \multicolumn{5}{c}{ Ínstares } \\
\cline { 2 - 6 } & $1^{\underline{0}}$ & $2^{\underline{0}}$ & $3^{\underline{0}}$ & $4^{\underline{Q}}$ & $5^{\underline{0}}$ \\
\hline Largura da cabeça & $0,92 \pm 0,07$ & $1,34 \pm 0,10$ & $1,70 \pm 0,05$ & $2,13 \pm 0,06$ & $2,73 \pm 0,07$ \\
& $(0,81-1,00)$ & $(1,25-1,56)$ & $(1,59-1,75)$ & $(2,03-2,19)$ & $(2,59-2,81)$ \\
Comprimento da cabeça & $0,67 \pm 0,10$ & $0,81 \pm 0,05$ & $1,01 \pm 0,18$ & $1,16 \pm 0,08$ & $1,57 \pm 0,06$ \\
& $(0,59-0,72)$ & $(0,75-0,94)$ & $(0,84-1,05)$ & $(1,06-1,31)$ & $(1,47-1,69)$ \\
Largura do pronoto & $0,85 \pm 0,08$ & $1,17 \pm 0,08$ & $1,42 \pm 0,17$ & $1,90 \pm 0,10$ & $2,50 \pm 0,07$ \\
& $(0,75-0,94)$ & $(1,09-1,34)$ & $(0,97-1,56)$ & $(1,72-2,03)$ & $(2,34-2,59)$ \\
Comprimento cabeça-tórax & $1,36 \pm 0,14$ & $1,73 \pm 0,17$ & $2,34 \pm 0,11$ & $2,82 \pm 0,15$ & $3,99 \pm 0,25$ \\
& $(1,25-1,70)$ & $(1,56-2,06)$ & $(2,19-2,53)$ & $(2,66-3,19)$ & $(3,75-4,66)$ \\
Comprimento total & $2,83 \pm 0,35$ & $3,30 \pm 0,68$ & $5,04 \pm 0,41$ & $5,97 \pm 0,67$ & $8,45 \pm 0,76$ \\
& $(2,47-3,06)$ & $(2,38-3,85)$ & $(4,53-5,78)$ & $(5,24-7,38)$ & $(7,50-10,28)$ \\
\hline
\end{tabular}



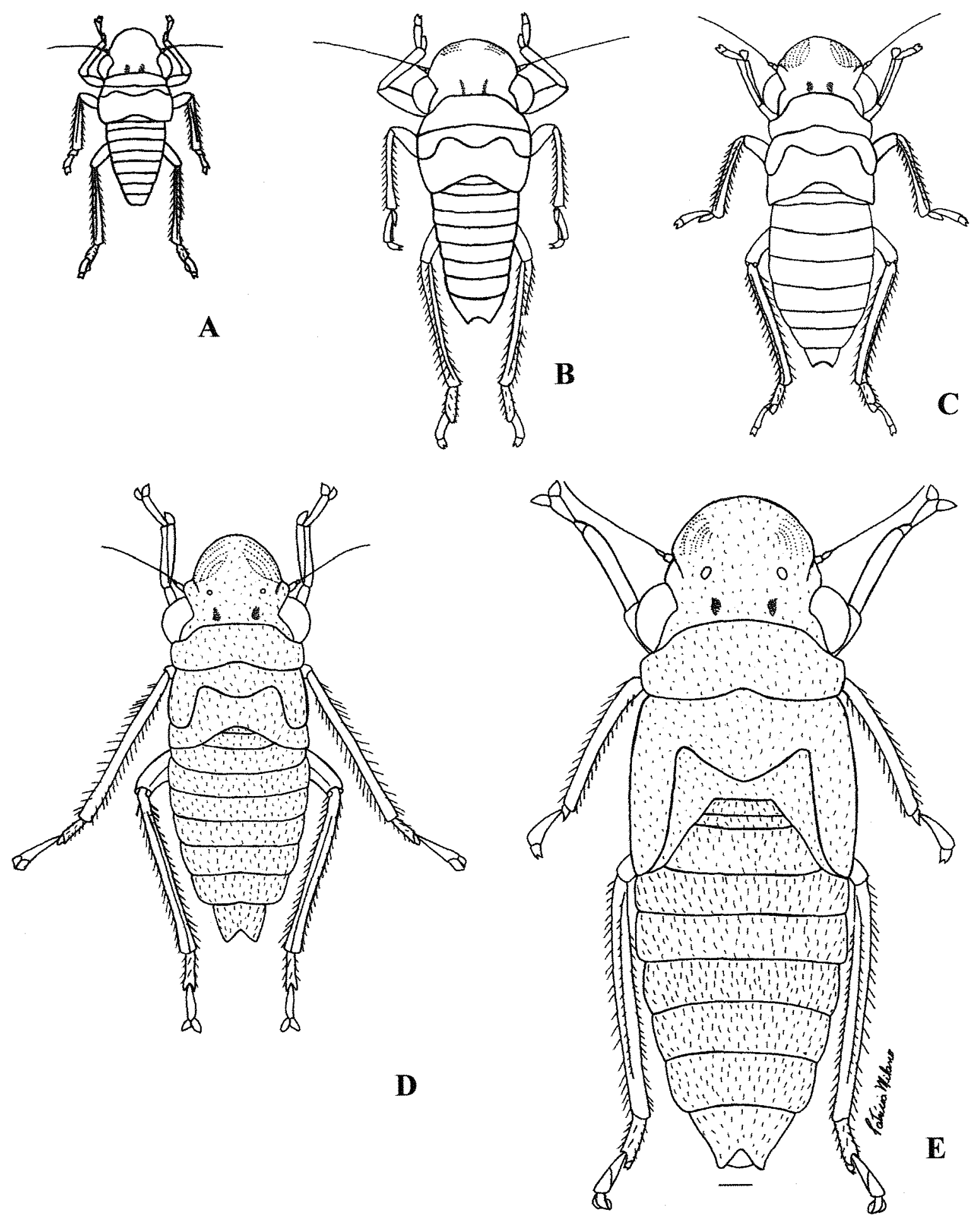

Figura 20 - Ninfas de Oncometopia facialis, vista dorsal: (A) $1^{\circ}$ ínstar; (B) $2^{\circ}$ ínstar; (C) $3^{\circ}$ instar; (D) $4^{\circ}$ ínstar; (E) $5^{\circ}$ ínstar (escalas: 0,4 mm). 


\subsubsection{Passagem da fase ninfal para a adulta}

\section{Acrogonia sp.}

As manchas amarelas presentes na cabeça e no tórax somente aparecem nos adultos, sendo que a intensidade aumenta alguns dias após a emergência. Dessa forma, o adulto recém-emergido apresenta uma coloração pálida. Os ocelos, nos adultos, situamse numa área mais ou menos elevada, o que não ocorre com as ninfas; a localização destes também é diferente, pois no adulto está atrás da linha imaginária entre os ângulos oculares anteriores e na ninfa aproximadamente sobre essa linha. Os lóbulos suprantenais já estão salientes desde o $3^{\underline{0}}$ ínstar . Em relação ao tamanho do corpo, as antenas no adulto são menores que nas ninfas. $O$ rostro é mais curto que a base das coxas II, no adulto. Tarsos trímeros nos três pares de pernas é observado somente no adulto. Há ausência de pubescência na superfície do corpo de ninfas e adultos.

\section{Dilobopterus costalimai Young, 1977}

Os lóbulos suprantenais não estão salientes nas ninfas e no adulto. Em relação ao tamanho do corpo, as antenas no adulto são menores que as nas ninfas. As ninfas já apresentam indícios de manchas escuras na cabeça e no tórax, que formam desenhos bastante característicos nos adultos. Não se observou nenhuma alteração característica nos brotos alares do mesonoto que daria origem ao lobo jugal alargado no adulto. As duas manchas escuras alongadas entre os olhos, próximas a margem posterior da cabeça, continuam presentes nos adultos, sendo que os ocelos se encontram no ápice dessas, o que não ocorre no quinto ínstar, em que a área ocelar é evidente. No adulto, o ocelo localiza-se atrás da linha imaginária entre os ângulos oculares anteriores e no quinto ínstar encontra-se antes da linha e não no ápice da mancha alongada escurecida. $O$ rostro não atinge as coxas II no adulto. Tarsos trímeros nos três pares de pernas ocorrem somente nos adultos. 


\section{Oncometopia facialis (Signoret, 1854)}

Desde os primeiros ínstares ninfais já se observa pubescência sobre a superfície do corpo. As duas manchas escuras entre os olhos, próximas a margem posterior da cabeça é reduzida no adulto, mas bem delimitada. A rugosidade observada no pronoto do adulto não ocorre nos ínstares ninfais. Em relação ao tamanho do corpo, a antena nos adultos é menor que nos ínstares ninfais. Os lóbulos suprantenais já se mostram salientes desde o $2^{\underline{0}}$ ínstar. No adulto, o rostro não atinge a base das coxas II. Somente o adulto apresenta tarsos trímeros nos três pares de pernas.

4.2.2 Chave para identificação das ninfas do $5^{0}$ ínstar de Acrogonia sp., Dilobopterus costalimai e Oncometopia facialis

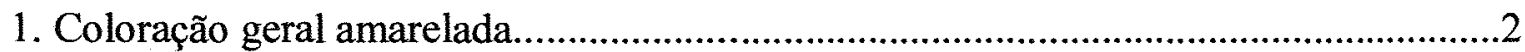
Coloração escura, área ocelar bem delimitada, ninfas robustas (Fig. 20E) Oncometopia facialis.

2. Ausência de manchas escuras na cabeça, tórax e abdome, espécies alongadas (Fig. 18E) Acrogonia sp.

Presença de manchas ou faixas escuras na cabeça, tórax e abdome (Fig. 19E) Dilobopterus costalimai

4.2.3 Chave para separação dos ínstares de Acrogonia sp., Dilobopterus costalimai, Oncometopia facialis

1. Brotos alares ausentes......................................................................................2

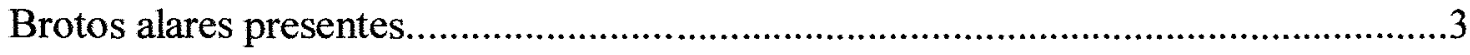

2. Mesonoto com os ângulos látero-posteriores levemente expandidos, porém mais curtos ou do mesmo tamanho que o lobo mediano (Fig. 21 A) ........................ $1^{0}$ instar 
Mesonoto com ângulos látero-posteriores expandidos, levemente mais longos que o lobo mediano (Fig. 21B) $2^{0}$ ínstar

3. Tórax aproximadamente tão largo quanto longo; brotos alares do mesonoto expandidos até a metade do metanoto.(Fig. 21C) ....................................... $3^{0}$ ínstar Tórax distintamente mais longo que largo; brotos alares do mesonoto ultrapassando a metade do comprimento do metanoto. .4

4. Brotos alares do mesonoto não se estendendo até a margem posterior do metanoto (Fig. 21D) $4^{0}$ ínstar Brotos alares do mesonoto alcançando a margem posterior do metanoto; escutelo surgindo na região mediana do metanoto, sobrepondo o metanoto; metatarsos trímeros (Fig. 21E). $5^{0}$ ínstar

\subsubsection{Chave para separação dos sexos de Cicadellidae baseada nos caracteres externos das ninfas do $3^{0}$ ao $5^{0}$ ínstar.}

1. Placa subgenital simples de forma triangular no $9^{0}$ esternito com uma pequena fenda apical em direção a base (comprimento da fenda ao longo da placa varia com a espécie); aumento de tamanho da placa de um ínstar para o outro, com manutenção da forma (Fig.22 A, $23 \mathrm{~A}$ e $24 \mathrm{~A}$ ). macho

2. Duas placas subgenitais pareadas na margem posterior do $8^{0}$ e $9^{0}$ esternitos $\left(3^{0}\right.$ ínstar $)$. Nos $4^{\underline{0}}$ e $5^{\underline{0}}$ ínstares uma valva adicional torna-se visível (posição lateral), e se expandem do $8^{0}$ para o $9^{0}$ esternito; fenda apical longa no $5^{0}$ instar, estendendo-se quase até a base das valvas, terceiro par de valvas de maior tamanho no $5^{0}$ ínstar, sendo somente visível o ápice do segundo par. (Fig. 22B, 23B e 24B)............... fềmea 


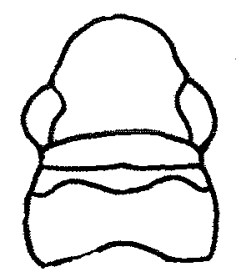

A

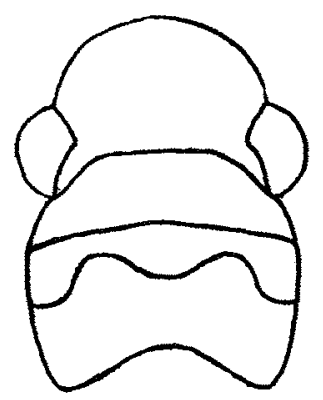

B

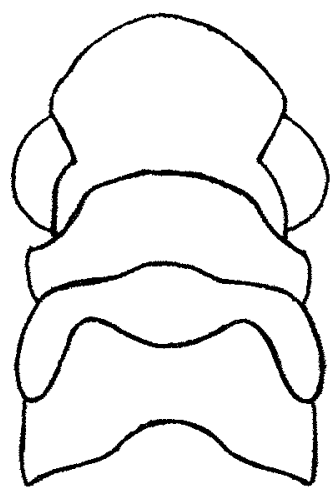

C

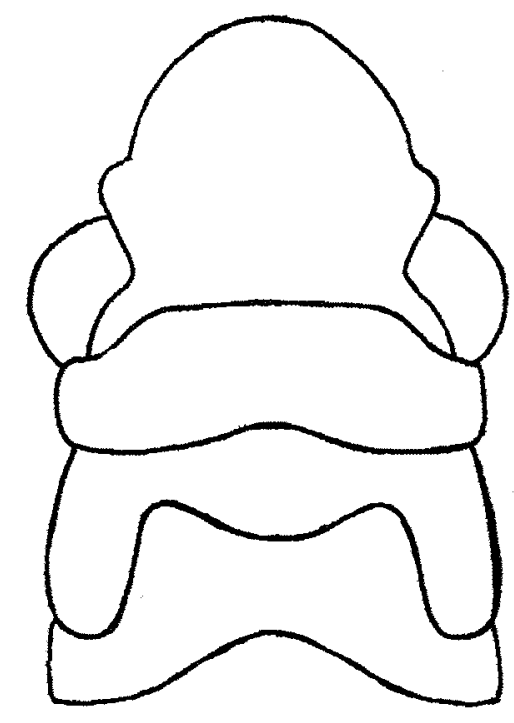

D

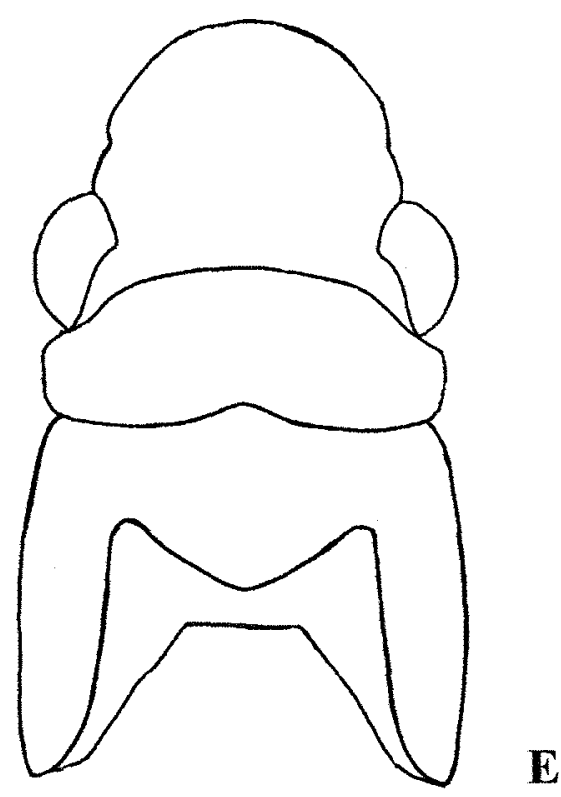

Figura 21 - Oncometopia facialis. Desenvolvimento dos brotos alares. (A) $1^{\underline{0}}$ ínstar; (B) $2^{\underline{0}}$ instar; (C) $3^{0}$ instar; (D) $4^{0}$ ínstar; (E) $5^{0}$ ínstar. 


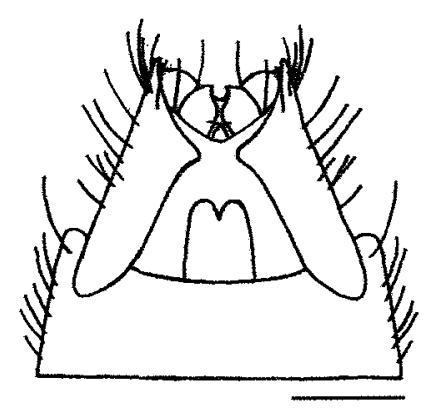

A

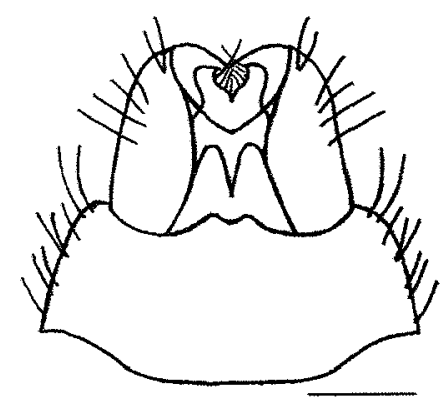

B

Figura 22 - Oncometopia facialis vista ventral dos dois últimos segmentos abdominais. (A) terceiro ínstar (macho); (B) terceiro ínstar (fềmea) (escala A: 0,2 mm; B: 0,25 $\mathrm{mm})$.

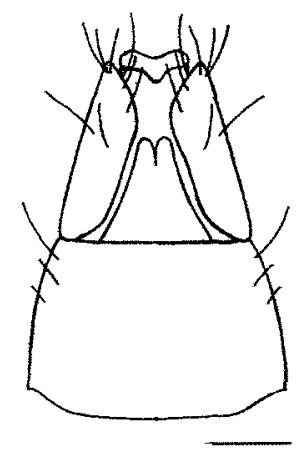

A

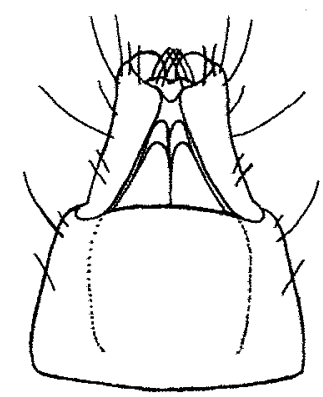

B

Figura 23 - Dilobopterus costalimai, vista ventral dos dois últimos segmentos abdominais. (A) quarto ínstar (macho); (B) quarto ínstar (fềmea) (escala A e B: 0,25 mm).

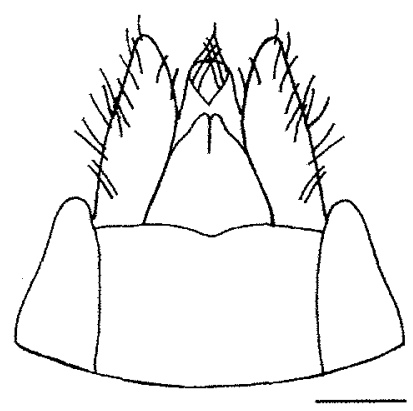

A

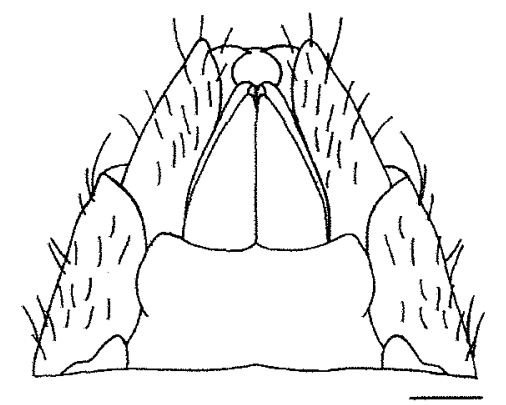

B

Figura 24 - Oncometopia facialis vista ventral dos dois últimos segmentos abdominais. (A) Quinto ínstar (macho); (B) quinto ínstar (fềmea) (escala A: 0,4 mm; B: 0,32 $\mathrm{mm}$ ). 


\section{CONCLUSÕES}

- Os caracteres externos das cigarrinhas do citros são úteis na separação de gêneros, mas a identificação específica é dependende dos caracteres da genitália masculina.

- As cigarrinhas apresentam caracteres externos muito variáveis, principalmente a cor.

- Os caracteres externos distiguem as cinco espécies de cigarrinhas vetoras de Xylella fastidosa: Acrogonia sp., Bucephalogonia xanthophis (Berg, 1879), Dilobopterus costalimai Young, 1977, Oncometopia facialis (Signoret, 1854) e Plesiommata corniculata Young, 1977.

- Nas três áreas amostradas houve um maior número de espécies pertencentes à tribo Cicadellini do que da tribo Proconiini.

- Na região de Bebedouro, as espécies Acrogonia sp., Bucephalogonia xanthophis, Dilobopterus costalimai e Oncometopia facialis foram coletadas em pomares cítricos e em todos os hábitats adjacentes amostrados.

- Há maior dificuldade na separação dos dois primeiros ínstares das espécies vetoras: Acrogonia sp., Dilobopterus costalimai e Oncometopia facilais.

- Baseando-se na morfologia é possível reconhecer os estágios imaturos das três espécies vetoras de $X$. fastidiosa, bem como diferenciar os ínstares e separar os sexos a partir do terceiro ínstar. 


\section{REFERÊNCIAS BIBLIOGRÁFICAS}

ALMEIDA, R.P.P.; LOPES, J.R.S.L. Desenvolvimento das cigarrinhas Dilobopterus costalimai e Oncometopia sp. (Hemiptera, Cicadellidae) em citros. In: CONGRESSO BRASILEIRO DE ENTOMOLOGIA, 16., Salvador, 1997. Resumos. Salvador: SEB, 1994. p.94.

AMARO, A.A.;ARAÚJO, C.M.; PORTO, O.M. et al. Panorama da citricultura brasileira. In: RODRIGUEZ, O. ; VIEGAS, F.; POMPEU Jr., J.; AMARO, A.A. (Ed.) Citricultura brasileira. Campinas: Fundação Cargil, 1991. v .1, cap.2, p.2254.

BLOCKER, H.D.; TRIPLEHORN, B.W. External morphology of leafhoppers. In: NAULT. L.R.; RODRIGUEZ. J.G. (Ed.) The leafhoppers and planthoppers. New York: John Wiley,, 1985. cap. 3, p.41-60.

BRLANSKLY, R.H.;TIMMER, L.W.;LEE, R.F. Detection and transmission of a gramnegative xylem-limited bacterium in sharpshooters from a citrus grove in Florida. Plant Disease, v.16, n.7, p.590-592, 1982.

BRLANSKLY, R.H.; TIMMER, L.W.; FRENCH, W.J. et al. Colonization of the sharpshooter vectors, Oncometopia nigricans and Homalodisca coagulata, by xylem-limited bacteria. Phytophathology, v.73, n.4, p.530-535, 1983. 
BROWNING, H.W.; McGOVERN, R.J.; JACKSON, L.K. et al. Florida citrus diagnostic guide. Florida: Science Source, 1995. 244p.

CAVICHIOLI, R. R. Sobre a biologia de Kanaima Fluvialis (Lallemand, 1924) (Homoptera, Cercopidae). Revista Brasileira de Entomologia, v.31, n.1, p.71-82, 1987.

CAVICHIOLI, R. R. ; SAKAKIBARA, A. M. Novo gênero e espécie de Proconiini (Homoptera, Cicadellidae). Revista Brasileira de Zoologia, v. 6, n. 1, p. 171-174, 1989.

CAVICHIOLI, R.R.; ZANOL, K.M.R. Espécies de Cicadellinae, Deltocephalinae (Homoptera, Cicadellinae) da Ilha de Maracá, Roraima. Acta Amazonica, v.21, p.55-61, 1991.

CLARIDGE, M.F. Acoustic signals in the Homoptera: Behavior, Taxonomy, and evolution. Annual Review of Entomology, v.30, p.297-317, 1985.

COELHO, L.B.N. Análise faunística de Cicadellidae (Insecta: Homoptera) em área de Mata Atlântica. Viçosa, 1997. 73p. Dissertação (M.S.) - Universidade Federal de Viçosa.

COLL, O.R. Clorosis variegada de los citrus en plantaciones de la zona de Montecarlo, Misiones, Argentina. Estudio sistematico y bioecologico de los cicadelidos (Homoptera: Cicadellidae) potenciales vectores del patogeno. Buenos Aires, 1996. 291p. Dissertação (M.S.) - Universidad Nacional de La Plata.

COLL, O. R.; LENICOV, A.M.M.R.; AGOSTINI, J.P. Xylella fastidiosa hosts detected by serological test in weeds and sharpshooters of Valencia sweet orange groves with CVC symptoms in the Montecarlo area. In: CONFERENCE OF 
INTERNATIONAL ORGANIZATION OF CITRUS VIROLOGISTS, 14., Campinas, 1998. Resumos. Campinas, 1998a. p.82.

COLL, O. R.; LENICOV, A.M.M.R.; AGOSTINI, J.P. et al. Some factors to be considered in a pest management program for valencia sweet orange groves with CVC. In: CONFERENCE OF INTERNATIONAL ORGANIZATION OF CITRUS VIROLOGISTS, 14., Campinas, 1998. Resumos. Campinas, 1998b. p.89.

DECOURSEY, R. M. ; ESSELBAUGH, C. O.. Descriptions of the nymphal stages of some north american Pentatomidae (Hemiptera - Heteroptera). Annals of the Entomological Society of America, v. 55. p. 323-3 41, 1962.

DELONG, D.M. The bionomics of leafhoppers. Annual Review of Entomology, v.16, p.179-210, 1971.

DE NEGRI, J. D. ; GARCIA JÚNIOR, A. Sugestões para o manejo de pomares com clorose variegada dos citros. Laranja, v.14, n.1, p. 177-200, 1993.

DERRICK, K. ; BERETTA, M.J.G. Métodos de detecção e identificação de strains de Xylella fastidiosa. Laranja, v. 17, n.1, p.233-236, 1996.

DIETRICH, C.H. Surface sculpturing of the abdominal in tegument of membracidae and other Auchenorrhyncha (Homoptera). Proceedings of the Entomological Society of Washington, v. 912, n.2, p. 143-152, 1989.

DIETRICH, C.H.; POOLEY. C.D. Automated identification of leafhoppers (Homoptera: Draeculacephala Ball).Annals of the Entomological Society of America, v.87, n.4, p.412-423, 1994. 
DOLLING, W.R. The Hemiptera. New York: Oxford University Press, 1991. cap.15, p.143-162: Auchenorrhyncha.

EMMRICH, R. Zur Kenntnis der Gattung Oncometopia STÅL, 1869 (Homoptera, Cicadelldae, Cicadelliane). Entomologishe Abhandlungen Staatliches Museum Für Tierkunde in Dresden, v. 40, n.9, p. 277-303, 1975.

EVANS, J.W. A natural classification of leafhoppers (Jassoidea: Homoptera). Transactions of the Royal Entomological of Society London,v.98, p.105-271,1947.

FNP CONSULTORIA. Agrianual-98: Anuário estatístico da agricultura brasuleira. São Paulo, 1998. p. 194-219.

FRAZIER, N.W. Phylogenetic relationship of the nine known leafhopper vectors of Pierce's disease of grape. Phytopathology, v.34, p. 1000-1001, 1944.

FREITAG, J.H. Host range of Pierce's disease virus of grapes as determined by insect transmission. Phytopathology, v.41, p.920-934, 1951.

FRENCH, W.J.; FELICIANO, A. Distribution and severity of plum leaf scald disease in Brazil. Plant Disease, v.66, p.515-516, 1982.

GARCIA JÚNIOR, A.; LOPES, J.R.S.; BERETTA, M. J.G. Population survey of leafhopper vectors of Xylella fastidiosa in citrus nurseries. Fruits, v.52, n.6, p. 371374, 1997.

GARCIA JÚNIOR. , A.; MAGGIONE, C.S.; TEÓFILO SOBRINHO, J. et al. Como conviver com a CVC em São Paulo. Laranja, v.16, n.2, p. 145-154, 1995. 
GRAVENA, S.; LOPES, J. R. S.; PAIVA, P. E. B. et al. Os vetores da Xylella fastidiosa. In: DONADIO, L.C.; MOREIRA, C. S. (Ed.) Clorose variegada dos citros. Bebedouro: Fundecitros, 1997. cap. 3, p.37-53.

HARRISON, R.G. Dispersal polymorphisms in insects. Annual Review of Ecology and Systematics, v.11, p.95-118, 1980.

HOPKINS, D.L. Natural hosts of Xylella fastidiosa in Florida. Plant Disease, v.72, n.5, p.429-431, 1988.

HORSFIELD, D. Evidence for xylem feeding by Philaenus spumarius (L.) (Homoptera: Cercopidae). Entomologia Experimentalis et Applicata, v.24, p.95-99, 1978.

KATHIRITHAMBY, J. Development of the external male and female genitalia in the imature stages of Cicadellidae (Homoptera). Journal of Entomology, v. 48, n. 2, p. 193-197, 1974.

KRÜGER, R. ; LOPES, M.T.V. de C.; SANTOS, J. S. et al. Transmission efficiency of Xylella fastidiosa to citrus by sharpshooters and identification of two new vector species. In: CONFERENCE OF INTERNATIONAL ORGANIZATION OF CITRUS VIROLOGISTS, 14., Campinas, 1998. Resumos. Campinas, 1998. p.81.

LARANJEIRA, F. F.; BERGAMIN FILHO, A.; AMORIN, L. et al. Spatio-temporal dynamics of citrus variegated chlorosis. In: CONFERENCE OF INTERNATIONAL ORGANIZATION OF CITRUS VIROLOGISTS, 14. Campinas, 1998. Resumos. Campinas, 1998. p.85.

LEE, R.F.; BERETTA, M.J.G.; HARTUNG, J.H. et al. Citrus variegated chlorosis: confirmation of a Xylella fastidiosa as the causal agent. Summa Phytopathologica, v.19, n.2, p.123-125, 1993. 
LOPES, J.R.S. Mecanismos de transmissão de Xylella fastidiosa por cigarrinhas. Laranja, v.17, n.1, p.79-92, 1996a.

LOPES, J.R.S. Transmissão de Xylella fastidiosa dos citros por cigarrinhas e biologia dos vetores. Laranja, v.17, n.1, p.240-242, 1996 b.

LOPES, J.R.S.; BERETTA, M.J.G.; HARAKAVA, R. et al. A. Confirmação da transmissão por cigarrinhas do agente causal da clorose variegada dos citros, Xylella fastidiosa. Fitopatologia Brasileira, v.21, p.343, 1996. Suplemento.

MAY, M.F.; BRIGGS, M. The origin and structure of brochosomes. Journal of Ultrastructure Research, v.2, p. 239-244, 1958.

MEJDALANI, G. L. Scopogonalia Paula Young, 1977: Morphology of the female genitalia and comparative notes on the Juliaca generic group (Homoptera, Cicadellidae). Revista Brasileira de Entomologia, v.39, n. 1, p. 193-202, 1995.

MELICHAR, L. Monographie der Cicadellinen I. Annales Musei Nationalis Hungarici. v.21, p. 195-243, 1924.

MENEZES, M. Contribuição ao estudo da subfamília Deltocephalinae (Homoptera: Cicadellidae) no Estado de São Paulo. Piracicaba, 1972. 146p. Tese (Doutorado) Escola Superior de Agricultura "Luiz de Queiroz", Universidade de São Paulo.

METCALF, Z. P. General catalogue of the Homoptera, Cicadelloidea. Part I. Tettigellidae. Washington:USDA, Agricultural Researche Service, 1965. 730p.

MOCHIDA, O. Discrimination of stadium and Sex of nymphs of Nephotettix cinctipes (Uhler) (Hemiptera: Cicadellidae). Applied Entomology and Zoology, v. 5, p. 4447, 1970. 
MÜLLER, H.J. Effects of photoperiod and temperature on leafhopper vectors. In: MARAMOROSCH, K.; HARRIS, K. (Ed.) Leafhoppers vectors and plant disease agents. New York: Academic Press, 1979. p.29-94.

NEVES, E.M.; POMPEU, R.B; NEVES, M.F. et al. A laranja no Estado de São Paulo: produção regional, destino e mercados. Laranja, v.16, n.2, p.37-61, 1995.

NIELSON, M. W. The leafhopper vectors of phytopathogenic viruses (Homoptera, Cicadellidae) taxonomy, biology, and virus transmission. Washington: USDA, 1968. 386p. (USDA. Technical Bulletin, 1382).

NIELSON, M. W. Leafhoppers systematics. In: NAULT, L.R.; RODRIGUEZ, J.G. (Ed.) The leafhoppers and planthoppers. New York: John Wiley, 1985. cap. 2, p.11-39.

NIELSON, M. W.; MAY, C.J., TINGEY, W.M. Developmental biology of Oncometopia alpha. Annals of the Entomological Society of America, v.68, n.3, p.401-403, 1975.

OLIVEIRA, C. M. Variação morfológica entre populações de Dalbulus maidis (DeLong \& Wolcott, 1923) (Hemiptera, Cicadellidae) de algumas localidades do Brasil. Piracicaba, 1996. 69p. Dissertação (M.S.) - Escola Superior de Agricultura 'Luiz de Queiroz", Universidade de São Paulo.

OSBORN, H. Neotropical Homoptera of the Carnegie Museum. Part.5. Report upon the collections in the subfamily Cicadellinae, with descriptions of new species. Carnegie Museum Annals, v.16, p. 155-249, 1926. 
PAIVA, P.E.B. ; SILVA, J.L.; GRAVENA, S. et al. Cigarrinhas de xilema em pomares de laranja do Estado de São Paulo. Laranja, v. 17, n. 1, p.41-54, 1996.

PARADELA FILHO, O.; SUGIMORI, M.H.; RIBEIRO, I.J.A. et al. Primeira constatação em cafeeiro no Brasil da Xylella fastidiosa causadora da clorose variegada dos citros. Laranja, v.16, n.2, p.135-136, 1995.

POLLARD, H.N.; YONCE, C.E. Significance of length of tibial spines relative to oviposition processes by some leafhoppers (Hemiptera: Cicadellidae). Annals of the Entomological of America, v.58, n.4, p.594-595, 1965.

PURCELL, A.H. Almond leaf scorch: leafhopper and spittlebug vectors. Journal of Economic Entomology, v.73, n.6, p.834-838, 1980.

PURCELL, A.H. Cigarrinhas na cultura de citros. In: SEMINÁRIO INTERNACIONAL DE CITROS - MIP, 3., Campinas, 1994. Anais. Campinas: Fundação Cargil, 1994. p.195-209.

PURCELL, A.H. Transmissão de Xylella fastidiosa dos citros por cigarrinhas. Laranja, v.17, n. 1, p.243-245, 1996.

PURCELL, A.H.; FINLAY, A.H. Evidence for non circulative transmission of Pierce's disease bacterium by sharpshooter leafhoppers. Phytopathology, v.69, n.4, p. 393394, 1979.

RAJU, B.C.; GOHEEN, A.C.; FRAZIER, N.W. Occurrence of Pierce's disease bacteria in plants and vectors in California. Phytopathology, v.73, n.9, p.1309-1313, 1983. 
RAKITOV, R. A. Post-moulting behavior associated with Malpighian tubule secretions in leafhoppers and treehoppers (Auchenorrhyncha: Membracoidea). European Journal of Entomology, v. 93, p. 167-184, 1996.

ROBERTO, S.R.; COUTINHO, A.; LIMA, J.E.O; MIRANDA, V.S. et al. Transmissão de Xylella fastidiosa pelas cigarrinhas Dilobopterus costalimai, Acrogonia terminalis e Oncometopia facialis em citros. Fitopatologia Brasileira, v.21, n.4, p. 517-518, 1996.

ROSSETTI, V.; DE NEGRI, D. Clorose variegada dos citros: revisão. Laranja, v.11, n. 1, p.1-14, 1990.

SALVA, R.A.; ROBERTO, S.R.; CARLOS, E.F. Situação da clorose variegada dos citros no Estado de São Paulo. Laranja, v.16, n.2, p.155-164, 1995.

SCHRÖDER, H. Taxionomische und tiergeographische studien an neotropischen Zikaden (Cicadellidae, Tettigelinae). Der Senckenbergischen Naturforschenden Gesellschaft, n. 499, p.1-93, 1959.

SCHRÖDER, H. Neue und wenig beckannte neotropische Tettigellinae, 2. (Ins., Homopt., Cicadellidae). Senckenbergiana Biologica, v.43, n. 2, p. 153-154, 1962.

SEVERIN, H.H.P. Spitle-insect vectors of Pierce's disease virus II. Life history and virus transmission. Hilgardia, v.19, p.357-382, 1949.

SIGNORET, V. Revue Iconographique des Tettigonides. Annales de la Societé Entomologique de France, v.1, n.3, p.349, 1853. 
SILVEIRA NETO, S. ; BRAZ, A.J.B.P.; ZUCCHI, R.A. et al. Levantamento de insetos sugadores em citros com coletor de sucção costal. Anais da Sociedade Entomológica do Brasil, v.12, n. 2, p.165-173, 1983.

SIMONET, D.F.; PIENKOWSKI, R.L. Temperature effect on development and morphometrics of the potato leafhopper. Environmental Entomology, v.9, p.789$800,1980$.

SOUTHWOOD, T. R. E. Ecological methods, with particular reference to the study of insect populations. 2.ed. London: Chapman and Hall, 1978. 524p.

SWAIN, R. B. Notes on oviposition and life history of the leafhopper Oncometopia undata Fabr. (Homoptera: Cicadellidae). Entomological News, v. 47, n. , p. 264266, 1936.

TRAVENSOLO, R.F.; LEITE JR., R.P. Hospedeiros alternativos de Xylella fastidiosa entre plantas invasoras de pomares de citros com clorose variegada. Fitopatologia Brasileira, v.21, p.336, 1996. Suplemento.

TRIAPITSYN, S.V.; RUSSEL, F. M.; BOSSART, J.L. et al. Egg parasitoids of Homalodisca coagulata (Homptera: Cicadellidae). Florida Entomologist, v.81, n.2, p. 241-243, 1998.

TUBELIS, A.; BARROS, J.C.S.M.; LEITE, R.M.V.B.C. Difusão da clorose variegada dos citros em pomares comerciais de laranja no Brasil. Laranja, v.14, n.1, p.239$254,1993$.

TURNER, W. F.; POLLARD, H.N. Life histories and behavior of five insect vectors of phony peach disease. Washington: USDA, 1959. 28p. (USDA. Technical Bulletin, 1188). 
WHITE, J.; STREHL, C.E. Xylem feeding by periodical cicada nymphs on tree roots. Ecological Entomology, v. 3, p. 323-327, 1978.

WILSON, M. R. ; CLARIDGE, M. F. Handbook for identification of leafhoppers and planthoppers of rice. Wallingford: $\mathrm{CAB}$ International, Natural Resources Institute, 1991. p. 121-128: Nymphal Identification.

YAMAMOTO, P.T. Cigarrinhas em citros no Estado de São Paulo. Laranja, v.17, n.1, p.237-239, 1996.

YOUNG, D. A. Taxonomic study of the Cicadellinae. Part 1, Proconiini. Washington: United States National Museum, 1968, 287p. (Bulletin, 261).

YOUNG, D. A. Taxonomic study of the Cicadellinae (Homoptera: Cicadellidae). Part2, New World Cicadelliini and genus Cicadella. Washington: North Carolina Agricultural Experiment Station, 1977. 1135p. (Technical Bulletin, 239).

ZANOL, K.M.R.; MENEZES, M. Lista preliminar dos cicadelídeos (Homoptera, Cicadellidae) do Brasil. Ilheringia, Série. Zoológica., v.61, n.9, p.9-65, 1982. 